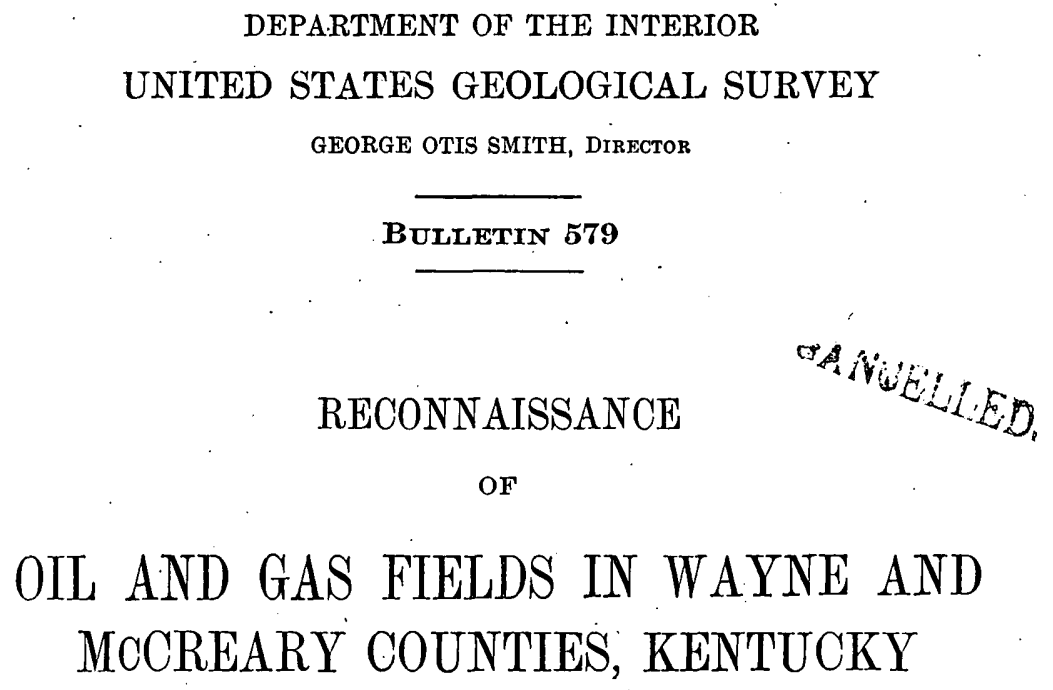

BY

M. J. MUNN

Prepared in cooperation with the Kentucky

Geological Survey

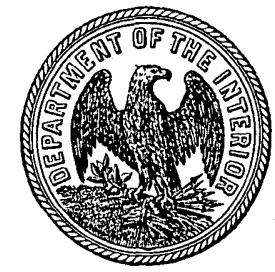

WASHINGTON

GOVERNMENT PRINTING OFFICE

1914 



\section{CONTENTS.}

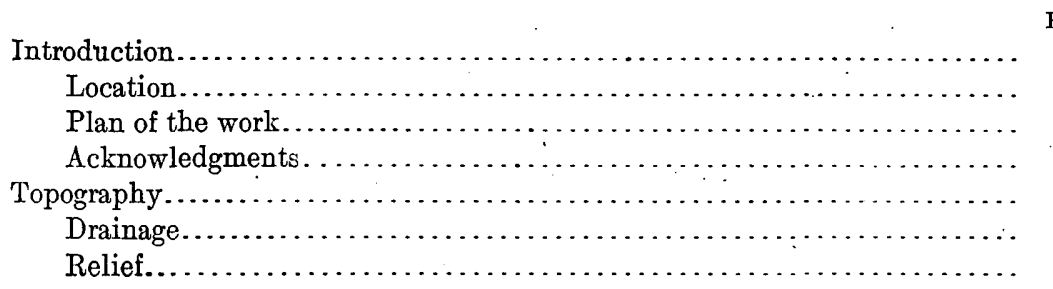

Geology................................................... 11

Stratigraphy............................................. 11

General character of the rocks.......................... 11

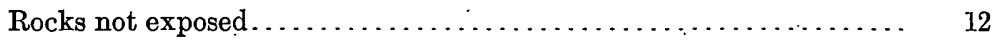

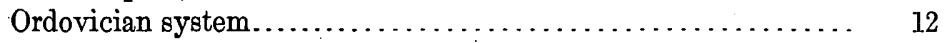

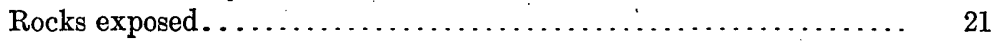

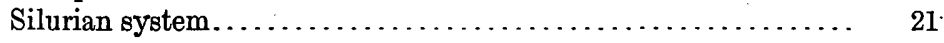

Devonian system. . . . . . . . . . . . . . . . . . . . . . $\quad 23$

Chattanooga shale............................. 23

Carboniferous system................................. 24

General character of the rocks...................... 24

Mississippian series............................ 24

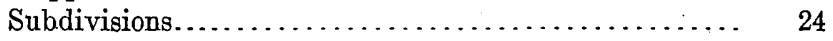

"Waverly" formation......................... 26

Lithologic character......................... 26

Oil sands.................................. 28

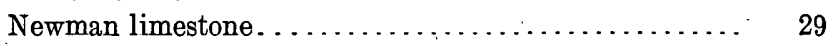

Pennington shale............................ 32

Lithologic character...................... $\quad 32$

Thickness............................... 33

Spann limestone member................... 33

Pennsylvanian series............................. 34

Pottsville group............................... 34

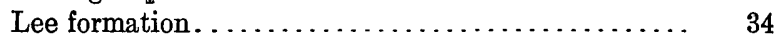

Lithologic character.................... 34

Rockcastle conglomerate member.......... $\quad 34$

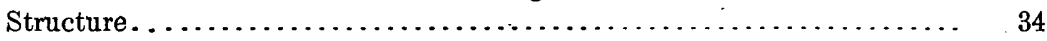

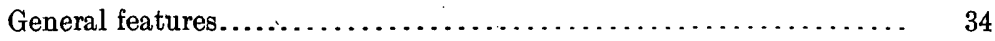

Method of mapping structure............................... 35

Accuracy of structure contours........................... 36

Structure of the Monticello district......................... $\quad 36$

Monticello syncline................................ 36

Spann anticline....................................... 37

Steubenville syncline............................... 37

Cooper anticline.................................... $\quad 38$

Sumpter syncline.............................. $\quad 38$

Structure of the Parmleysville district.................... 38 


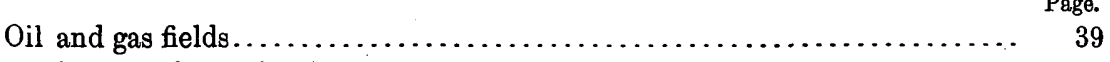

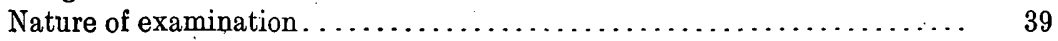

Steubenville oil field and adjacent territory $\ldots \ldots \ldots \ldots \ldots \ldots \ldots \ldots \ldots . \ldots \ldots$

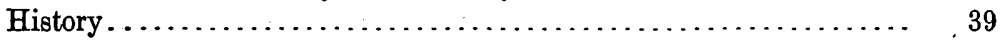

Oil sand...................................... 40

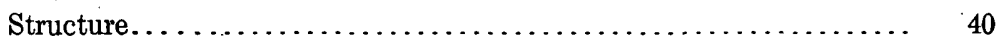

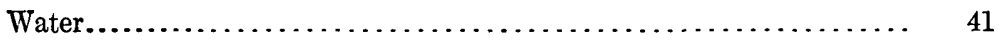

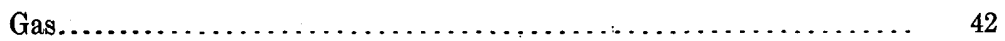

Test wells adjacent to the Steubenville field. . . . . . . . . . . . 42

Sinking oil field $\ldots \ldots \ldots \ldots \ldots \ldots \ldots \ldots \ldots \ldots \ldots \ldots \ldots \ldots \ldots \ldots \ldots \ldots \ldots \ldots$

Bratcher Hollow oil pool . . . . . . . . . . . . . . . . . . 46

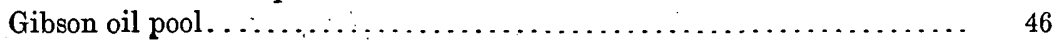

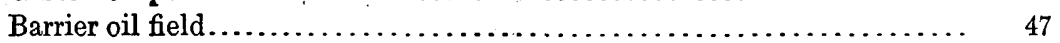

Cooper-Oil Valley oil field and the western part of Wayne County . . . . . 47

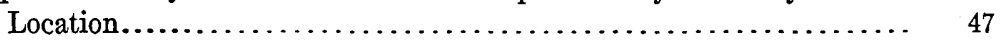

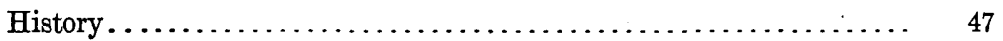

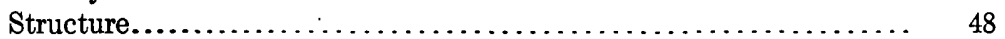

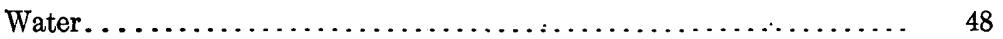

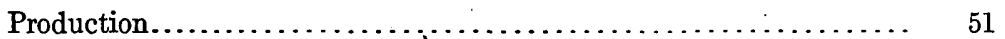

Test wells in the western part of Wayne County ............... 51

Northern and eastern parts of Wayne County $\ldots \ldots \ldots \ldots \ldots \ldots \ldots \ldots \ldots \ldots . \ldots 2$

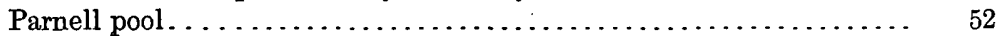

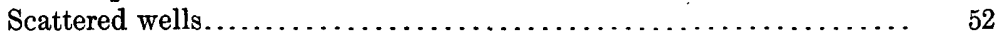

Scattered wells and small pools in the southern part of Wayne County... 53

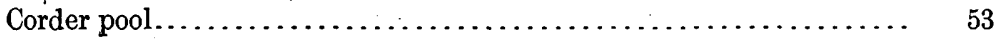

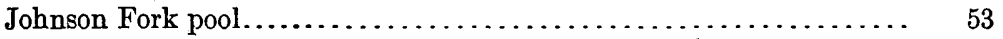

Rocky Branch pool................................. 54

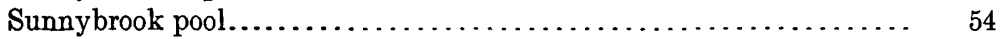

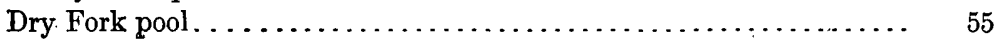

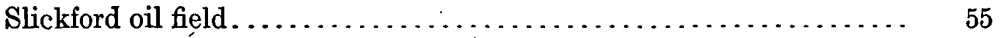

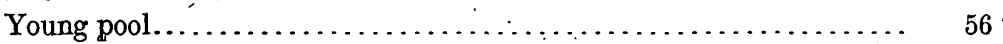

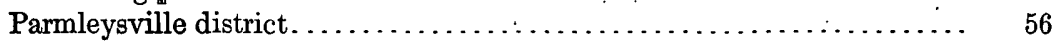

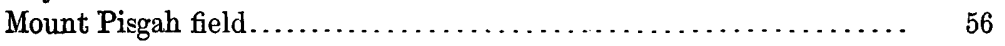

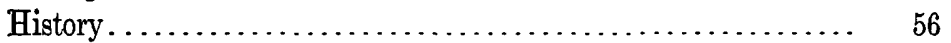

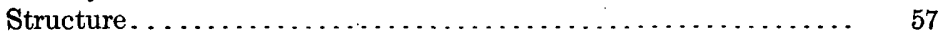

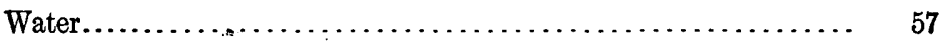

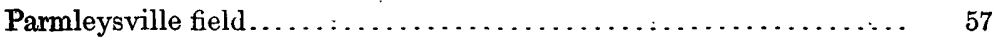

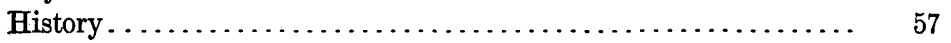

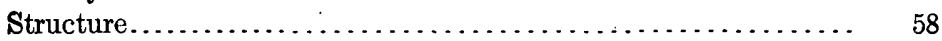

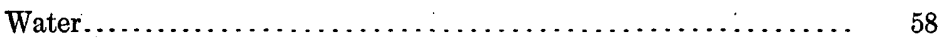

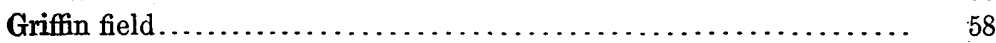

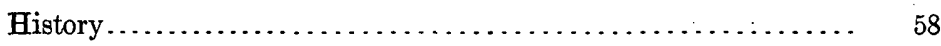

Structure. . . . . . . . . . . . . . . . . . . . . . 59

Water. . . . . . . . . . . . . . . . . . . . . 60

Future extensions of the Griffin field................ 60

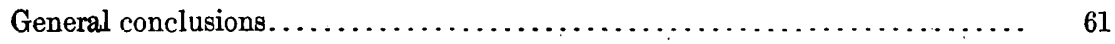

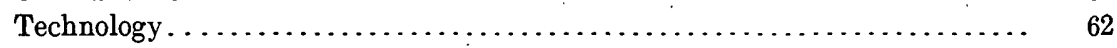

Analyses of oil from Wayne County pools. . . . . . . . . . . . . . . . . 62

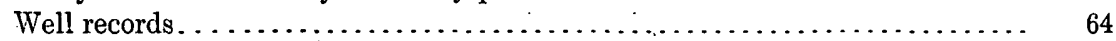

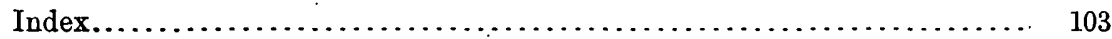




\section{ILLUSTRATIONS.}

Plate I. Specimens of Beaver Creek oil "sand," from oil wells in Wayne County, Ky.: $A$, From the Griffin field; $B$, From the Mount Pisgah field

Page.

II. Specimens of Beaver Creek oil "sand," from oil wells in Wayne County, Ky.: $A$, A very porous specimen of the Beaver Creek "sand," showing polished surface; $B$, A small part of the specimen shown in $A$, enlarged

III. Topographic map of the southeastern part of the Monticello quadrangle, $\mathrm{Ky}$

IV. Sketch map of Wayne County, Ky., showing location of oil and gas pools.

V. Farm-line map of the southern part of Wayne County, $\mathrm{Ky} . . . .$.

VI. Sketch map of the Little South Fork oil district.................

Figure 1. Index map showing location of area examined in Wayne and McCreary counties, Ky............................ 7

2. Sections of deep wells in Wayne County, Ky.............. 16

3. Diagrammatic section from east to west across the axis of the Cincinnati anticline in southern Kentucky................ 22

4. Generalized section of rocks exposed in Wayne County, Ky..... 25

5. Sketch map of the Sinking oil field, Wayne County, Ky........ 45

6. Sketch map of the part of the Cooper-Oil Valley field north of Sumpter post office.................................. 



\title{
RECONNAISSANCE OF OIL AND GAS FIELDS IN WAYNE AND MCCREARY COUNTIES, KENTUCKY.
}

\author{
By M. J. Munn.
}

\section{INTRODUCTION.}

LOCATION.

Wayne County lies in the southern part of Kentucky east of Cumberland River. It is bounded by Tennessee on the south, McCreary and Pulaski counties on the east and northeast, Russell County on the northwest, and Clinton County on the west. McCreary

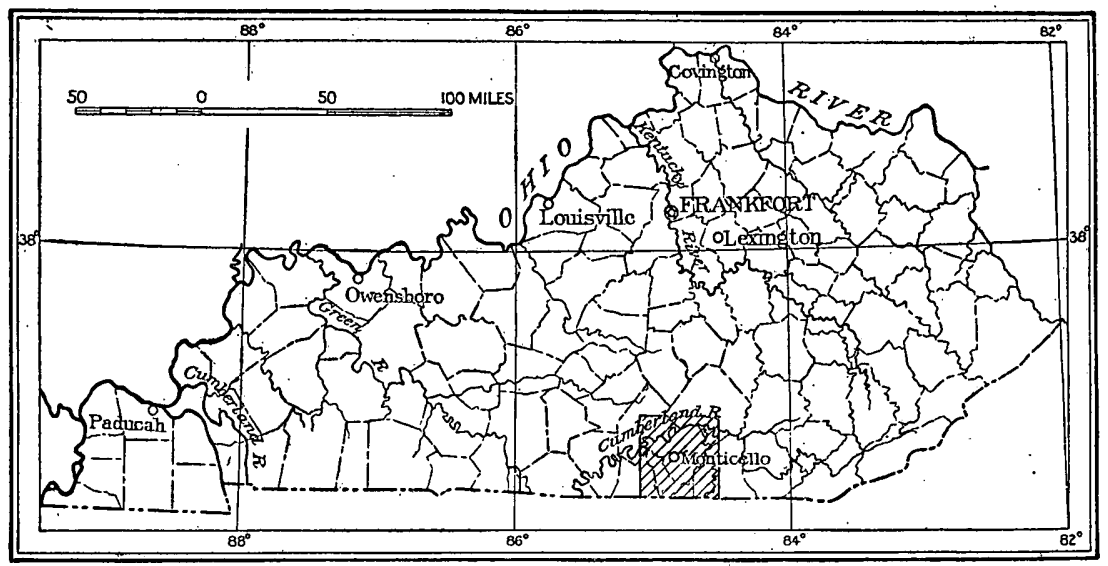

Figure 1.-Index map showing location of area examined in Wayne and McCreary counties, Ky.

is a new county created in 1912 from portions of Wayne, Whitley, and Pulaski counties. The portion formerly in Wayne County includes some of the areas covered by this report. (See fig. 1.)

\section{PLAN OF THE WORK.}

In connection with the preparation of a report on the oil and gas fields of the southern Appalachian region, it was planned to make in 1909 a general reconnaissance examination of the oil and gas develop- 
ments of eastern Keniucky and to study a few typical fields of that region in detail. In order to make the examination more comprehensive and at the same time to gain the advantage of an earlier publication of the result arrangements were made for the cooperation of the State with the Federal Survey in prosecuting the field work. ${ }^{1}$ This cooperation made possible detailed mapping of the structure of the Campton oil pool in Wolfe County, the Ragland oil field in Bath County, the Menifee County gas field, and the séveral fields described in this report-the Steubenville, Sinking, Oil Valley, Cooper, Mount Pisgah, Parmleysville, and Griffin oil fields.

The amount and nature of the material brought to light by the work in Wayne and McCreary counties seems to merit special discussion and presentation, and this bulletin is therefore published. Short reports on the Campton oil pool ${ }^{2}$ and on the Menifee gas field and Ragland oil field ${ }^{3}$ have already been published.

During July and August, 1911, the writer spent two weeks in field work in Wayne County and his assistant, Mr. M. W. Crouch, spent three weeks. During July and August, 1911, about six weeks' work was done by the writer and in the latter part of November of that year he made a visit of three or four days to the field.

When the field work was begun, topographic maps were available for only that part of Wayne County which is covered by the southern half of the Monticello quadrangle of the United States Geological Survey, and for this reason it was at that time thought best to confine detailed structural work to oil and gas fields within the quadrangle. After the structure of these oil pools was determined, similar work was extended to the.Mount Pisgah, Parmleysville, and Griffin fields, lying along the valley of the Little South Fork of Cumberland River in the southern part of the county, in order to compare the structure and altitude of the Beaver Creek "sand" in the two districts. For this work spirit-level lines were run from a bench mark of the United States Geological Survey in the southern part of the Monticello quadrangle to most of the wells in the Mount Pisgah and Griffin fields and to a large number of wells in the northern and eastern portions of the Parmleysville field in order to determine the altitudes of the wells above sea level. At the same time a rough topographic map (Pl. VI, p. 56) was made of the area covered, and the positions of the wells were marked upon it.

Logs of most of the wells to which levels were run were furnished by the oil producers, making it possible to determine the altitude of

\footnotetext{
1 See Kentucky Geol. Survey Rept. Progress for 1908 and 1909, p. 92, 19i0. In addition to the sum of $\$ 300$ first contributed by the State Survey, other aid in the way of field assistance was rendered by the State in 1911, when the last observations were made in this field.

2 Munn, M. J., The Campton oil pool, Ky.: U. S. Geol. Survey Bull. 471, pp. 9-17, 1912.

8 Munn, M. J., The Menifee gas field and the Ragland oil field, Ky.: U. S. Geol. Survey Bull. 531, pp. 9-26, 1913.
} 
the oil sand above sea level, which, in turn, reveals the dip or structure of the oil sand. In the southeast quarter of the Monticello quadrangle the oil fields are too widely scattered to admit of accurate structural mapping of the oil sand itself, and therefore, instead of determining the altitude of the oil sand in that area, it was found best to obtain the altitudes of an outcropping bed, the Spann limestone member of the Pennington shale, as shown on Plate III (p. 34).

\section{ACKNOWLEDGMENTS.}

The writer wishes to acknowledge his indebtedness to Prof. C. J. Norwood, director of the Kentucky Geological Survey, for a base for the sketch map of Wayne County and for many helpful suggestions; and to almost every oil and gas producer in the district for well records, maps, histories of development, and data relative to operations. Special acknowledgments are made to J. A. Patton, Roy Snyder, E. J. Purtle, Vogler Bros., I. C. Ramsey, R. A. Dempsey, O. B. Cutting, the Kimball Oil Co., G. W. Smith, J. E. Jones, E. A. McElhaney, Jos. Marsh, Charles Smith, the Esperanza Oil Co., V. Southwood, G. E. Backer, A. E. Rosenburger, E. T. Caffrey, P. M. Berwald, C. C. Kimball, and J. T. Walster. The writer has also made liberal use of the previously published geologic material pertaining to southeastern Kentucky, among which should be especially mentioned that by A. F. Foerste and J. B. Hoeing.

\section{TOPOGRAPHY.}

DRAINAGE.

Wayne County is drained by Cumberland River, which flows through its northern part. South Fork of Cumberland River, which marks part of the eastern border of Wayne County, receives the waters of Rock Creek, Little South Fork, and Big Sinking Creek. These drain the eastern part of Wayne County, and South Fork and Little South Fork drain the western part of McCreary County. The western part of Wayne County is drained into Cumberland River through Otter and Beaver creeks and their tributaries. These two creeks unite a short distance above their junction with Cumberland River. One of the principal tributaries of Beaver Creek is Elk Spring Creek, which flows from large springs at and near Monticello. These springs are probably outlets of underground streams which drain Elk Spring Valley south of Monticello and other smaller areas in that vicinity.

In the large interstream areas north of Monticello and Steubenville, in the vicinity of Alex, Murl, and Susie, and in the Shearer and Elk Spring valleys, there is no fully developed system of surface 
drainge. In these areas the run-off flows into numerous sink holes in the limestones that underlie the surface and appears again as large springs at the heads of the small streams along the margins of the plateau next to the principal drainage courses. The small streams from springs on adjacent hillsides disappear within short distances after entering these valleys, and some of them evidently make up fairly well developed systems of underground drainage.

\section{RELIEF.}

Two distinct types of topography are present in Wayne County. In the northwestern part, as far south as. Monticello, the surface is a fairly level plain having an altitude between 900 and 1,100 feet. This surface is broken by a few isolated well-rounded hills that rise to heights of 1,200 to 1,400 feet above sea level. Beaver and Otter creeks and their tributaries have deep, gorgelike valleys. Along the lower courses of these streams and immediately adjacent to Cumberland River the surface is deeply and minutely dissected by short, rapid streams.

The country lying southeast of Monticello consists of several chains of high hills, separated by the valleys of the principal streams. These ridges rise from 1,400 to about 1,700 feet above sea level, the highest points being near the southern edge of the county. The topography is mature. The thick sandstones and shales, which cap the hills and form their slopes for a distance below the summits of 100 to more than 400 feet, are minutely dissected by numerous small streams. The tops of the hills and ridges are very narrow and sharp except at a few isolated places on the highest ridges, where small, flat-topped, mesalike surfaces are maintained by remnants of a massive quartz conglomerate. Surface streams are numerous in this part of the county, wherever they flow over sandstones and shales; but on reaching the lower valleys, where limestones are exposed, many of the streams disappear in sink holes. A notable example of this type of drainage is the "Blue Hole," southwest of Burfield post office. "This valley is several miles in length and from 100 to probably more than 400 feet below the adjacent hills, by which it is said to be entirely surrounded, the stream which drains it disappearing in a sink hole.

The topography of Wayne County is very similar to that along the western border of the Appalachian-Cumberland plateau from Ohio to Alabama. The physiographic questions involved in a discussion of the topographic development of the surface of this county are therefore regional in their scope, and they do not constitute an appropriate subject for detailed discussion in an economic bulletin. 


\section{GEOLOGY.}

\section{STRATIGRAPHY.}

\section{GENERAL CHARACTER OF THE ROCKS.}

As shown in figures 2 and 4 (pp. 16 and 25), the rocks of Wayne County consist of limestone, sandstone, shale, clay, coal, and other material and are all of sedimentary origin. The bodies of water in which the material composing these rocks was deposited are supposed to have varied at different times from fairly deep, quiet, widespread, epicontinental seas to large bays, estuaries of fresh or brackish water, fresh-water lakes, swamps of all sizes, and temporary floods of rivers and smaller streams. The rocks range in age from limestone of Ordovician age, found in the deepest wells, up to surficial flood-plain deposits of the present streams. Beneath the lowest level reached by wells in Wayne County lies a great thickness of sedimentary rocks concerning the character of which no local data are available.

For convenience of discussion in this report the rocks are divided into two groups - those that are exposed at the surface and those that are entirely concealed but have been penetrated in deep wells. The Chattanooga ("Black") shale, lying practically at the base of the exposed rocks, is taken as the dividing bed between the exposed and unexposed rocks.

The strata which outcrop in Wayne County have a maximum thickness ranging between 1,200 and 1,500 feet. At the top they consist of sandstone, shale, conglomerate, clay, and coal belonging to the Pennsylvanian series ("Coal Measures") of the Carboniferous system. These beds are underlain by about 1,000 feet of limestone, shale, and thin sandstone, belonging to the Mississippian series ("sub-Carboniferous"), which constitutes the lower part of the Carboniferous system. The Pennsylvanian rocks are absent over the northern part of the county and along the principal streams, having been removed by erosion. They attain their maximum thickness, probably 400 or 500 feet, in the high hills along the southern border of the county. The limestones and the red and green shales of the upper part of the Mississippian series are exposed along the valleys and hillsides of the mountainous region, and the limestones of the middle and lower part form the surface of the rolling plain in the northern and western portions of the county. Cumberland River and some of its tributaries have cut their valleys as much as 200 feet into older rocks below the Carboniferous system. These older beds consist of 20 to 40 feet of Devonian shale at the top, underlain unconformably by Silurian or. Ordovician limestones down to water level. Over 1,500 feet of rocks, mostly limestones, which are not exposed at the 
surface, are known to have been pierced by a few deep wells. The formations are described in the order of their deposition, beginning with the lowest and oldest.

\section{ROCKS NOT EXPOSED. \\ ORDOVICIAN SYSTEM.}

The oldest rocks in Wayne County reached by a well of which any record is available were found in the $\mathrm{H}$. McBeath well No. 1, threefourths of a mile southwest of Steubenville. This well (fig. 2, p. 16) was drilled by Vogler Bros. for the New Domain Oil \& Gas Co., their record being as follows:

Record of H. McBeath well No. 1.

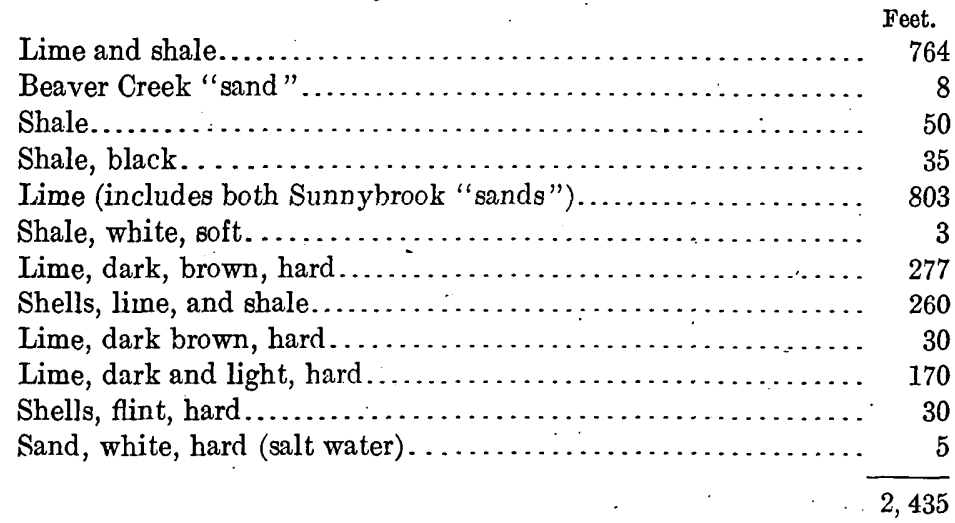

The following records of deep wells in other portions of Wayne County show the character of the rocks encountered as interpreted by the drillers (see fig. 2):

Record of Jordan \& McGowan well No. 1.

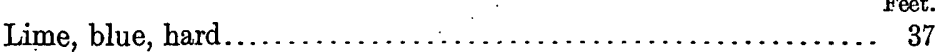

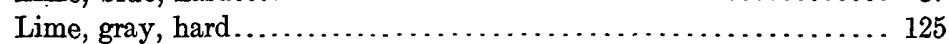

Lime, brown, hard ................................... 158

Slate, gray, soft................................... 32

Beaver Creek "sand," hard .............................. 3

Slate, gray, soft.................................... 2

Shale (Chattanooga), black......................... 40

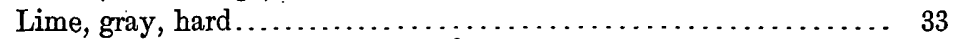

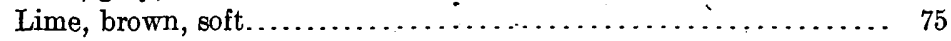

Little pockets of gas at 505 feet.

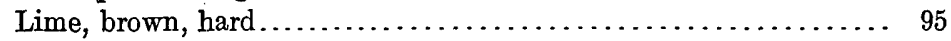

Lime, gray, hard................................... 50

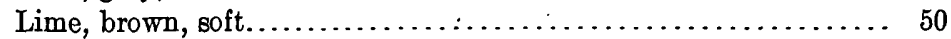

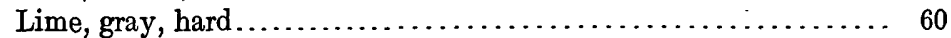

Lime, brown, hard .................................. 70

Top of Sunnybrook at 830 feet.

Lime, brown, hard, sharp.......................... 80 
Lime, gray, hard, sharp.

Top of "Pencil cave" at 1,000 feet.

"Pencil cave," soft.................................. 3

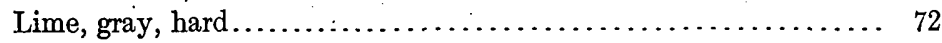

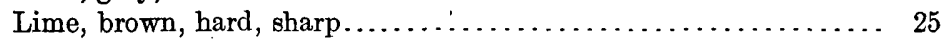

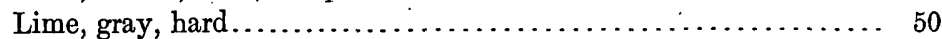

Lime, brown, hard, sharp......................... 50

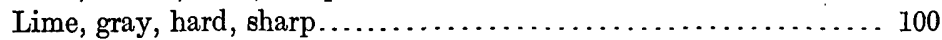

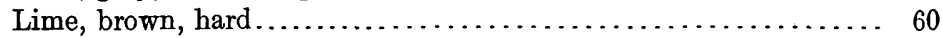

Lime, gray, soft.................................. 30

Lime, brown, hard................................ 110

Lime, gray, soft.................................. 40

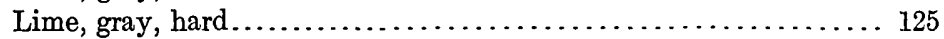

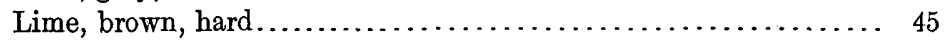

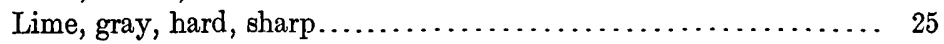

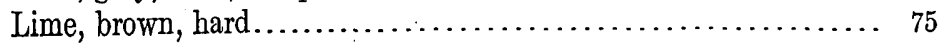

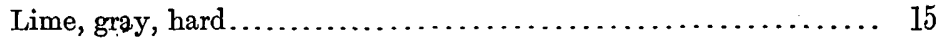

Lime, brown, hard, sharp.......................... 27

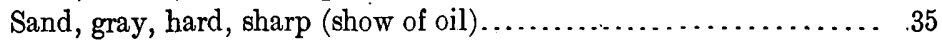

Unrecorded.................................... 24

Soapstone.................................... 10

Total depth, 1,921 feet.

The following is the log of the J. W. Barnes well No. 1, near Murl post office. This well was drilled by E. M. Williams and was completed August 24, 1903.

Record of J. W. Barnes well No. 1.

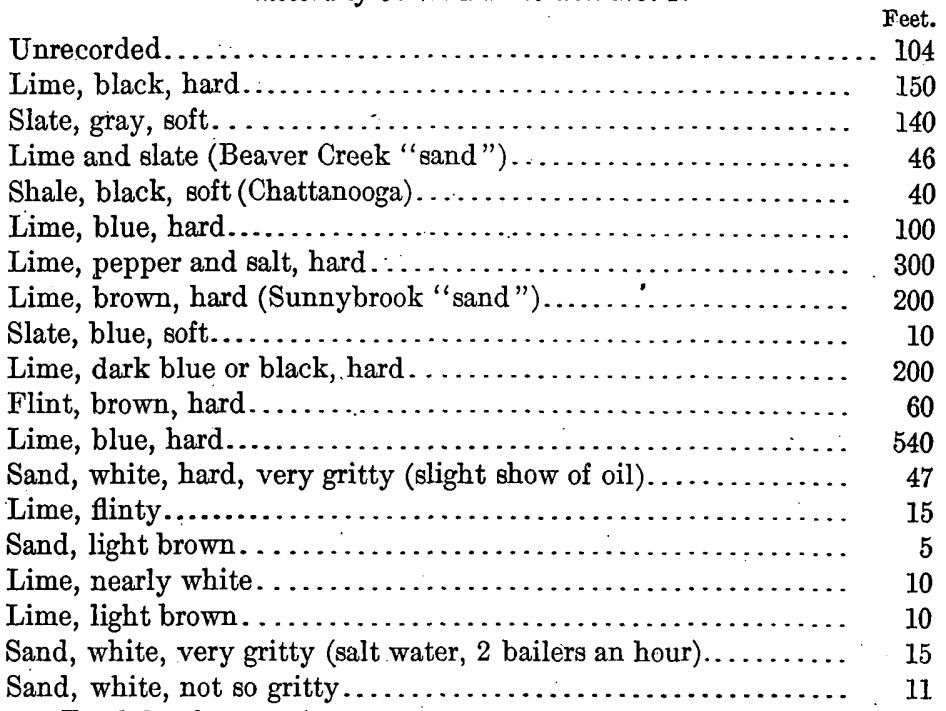

Total depth, 2,003 feet.

The following record is that of the Cyrus Brown well No. 1 of the New Domain Oil \& Gas Co., in the Sinking oil field. This well was drilled by C. C. Reeder and was completed on September 8, 1904. 
Record of Cyrus Brown well No. 1.

Limestone, white, hard (stray vein of water at 85 feet) Feet.

Limestone, bluish white, dry, hard . . . . . . . . . . . . . . . . 10

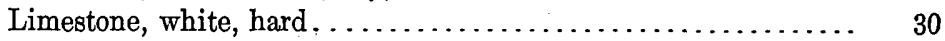

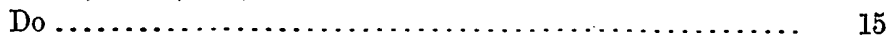

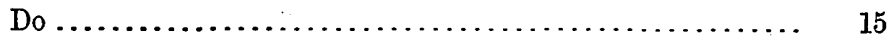

Limestone, dark, hard (gas at 205 feet).................. $\quad 30$

Limestone, dark, hard . . . . . . . . . . . . . . . . . . . . . . $\quad 39$

Limestone, white, hard ........................... $\quad 20$

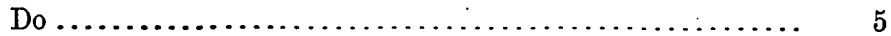

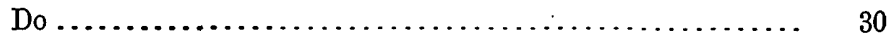

Limestone, black, hard (gas at 305 feet) $\ldots \ldots \ldots \ldots \ldots \ldots \ldots . \quad 30$

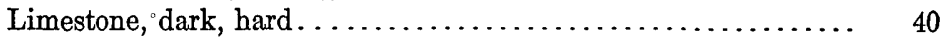

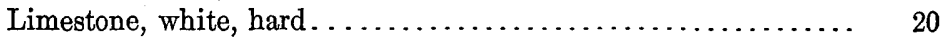

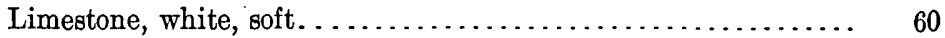

Do............................................ 56

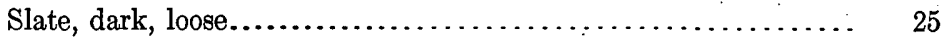

Hard shell. . . . . . . . . . . . . . 10

"Sand," white, soft (Beaver Creek)...................... 13

Shale, dark, loose (Chattanooga) . . ................... $\quad 40$

Sand, dark, loose................................ $\quad 15$

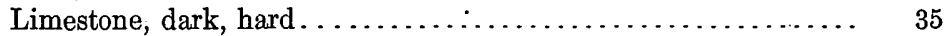

Limestone, dark, loose ........................... $\quad 50$

Limestone, dark, hard ........................... $\quad 40$

Do............................................. 352

Limestone, brown, hard ............................ $\quad 20$

Limestone, brown, loose......................... $\quad 40$

Do....................................... 40

Limestone, brown, hard........................... 210

Limestone, dark, hard .......................... 45

Flint, dark, hard................................ 5

Limestone, dark, hard ......................... 152

Total depth, 1,497 feet.

The following record is that of the E. R. Walker well No. 1, of the New Domain Oil \& Gas Co., in the Sinking oil field. This well was drilled by Peter Bros. and was completed October 7, 1904.

Rock at 8 feet.

Record of E. R. Walker well No. 1 .

Fresh water at 65 feet. Feet:

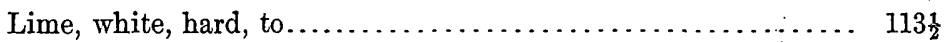

Lime, white, soft................................. 20

Lime, white, hard................................ 40

Lime, blue, soft.............................. 8

Lime, sandy, white, hard ............................ 7

Lime, white, hard (show of gas) $\ldots \ldots \ldots \ldots \ldots \ldots \ldots \ldots \ldots .20$

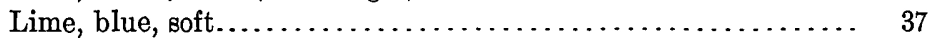

Lime, blue, soft.................................... 5

Lime, white, hard.............................. 50

Lime, sandy, white, hard ......................... 20 


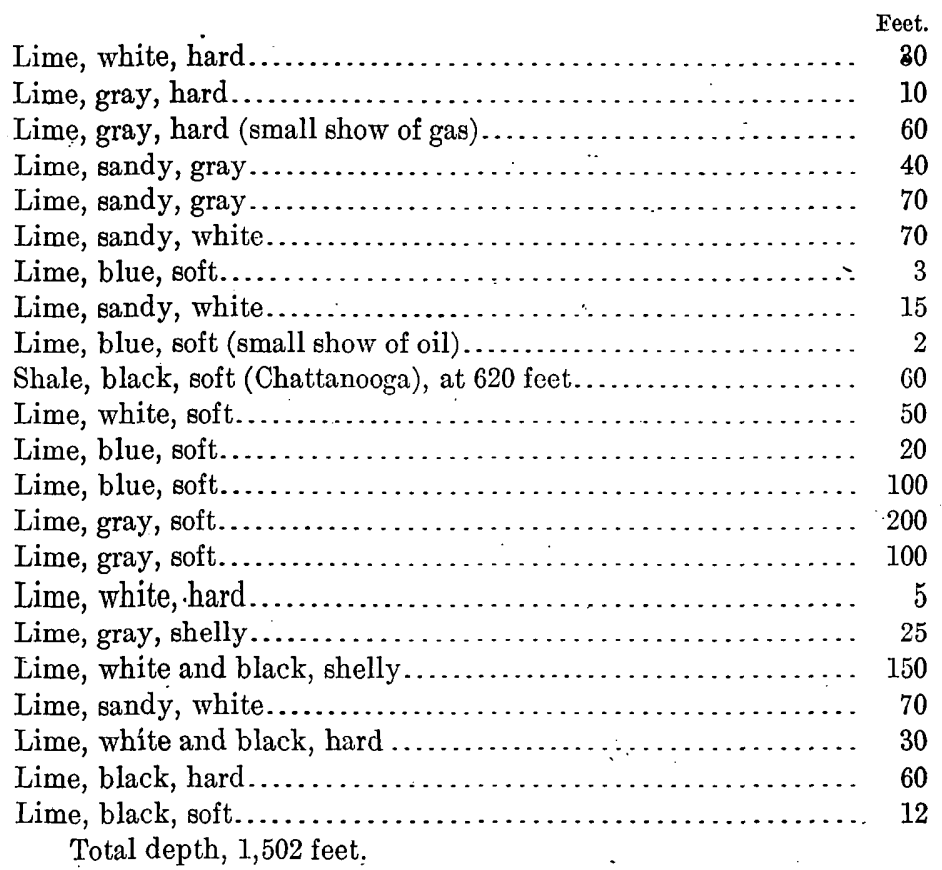

The following record is that of the Rock Creek Property Co. well No. 2 , in the Griffin oil field. This well was drilled by the New Domain Oil \& Gas Co. and was completed July 29, 1909.

Record of Rock Creek Property Co. well No. 2, Griffin district, Wayne County, Ky.

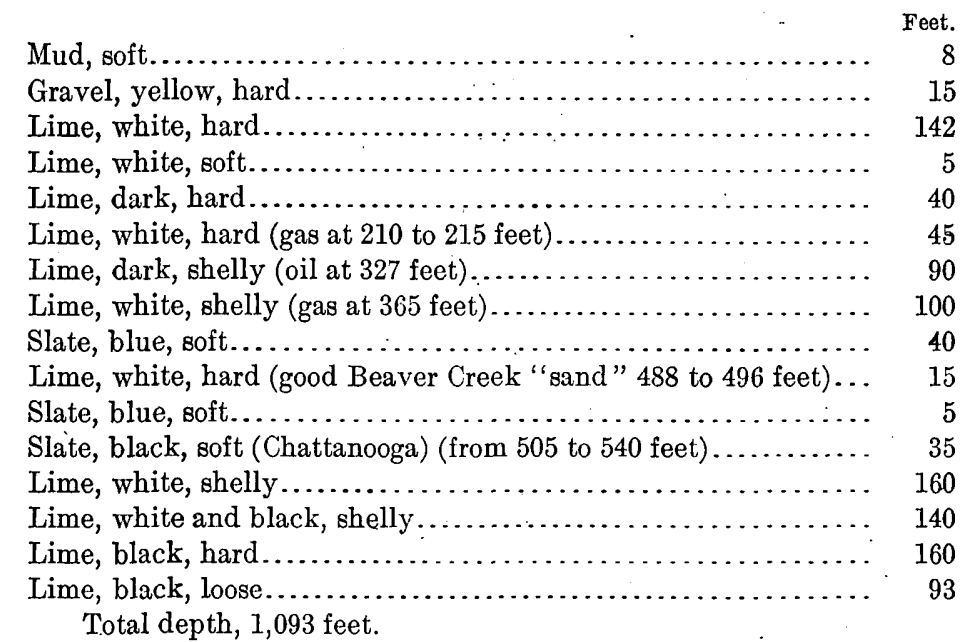

That portion of the above records describing rocks below the Mississippian series is shown in figure 2, which is drawn to scale. $29755^{\circ}-$ Bull, $579-14-2$ 


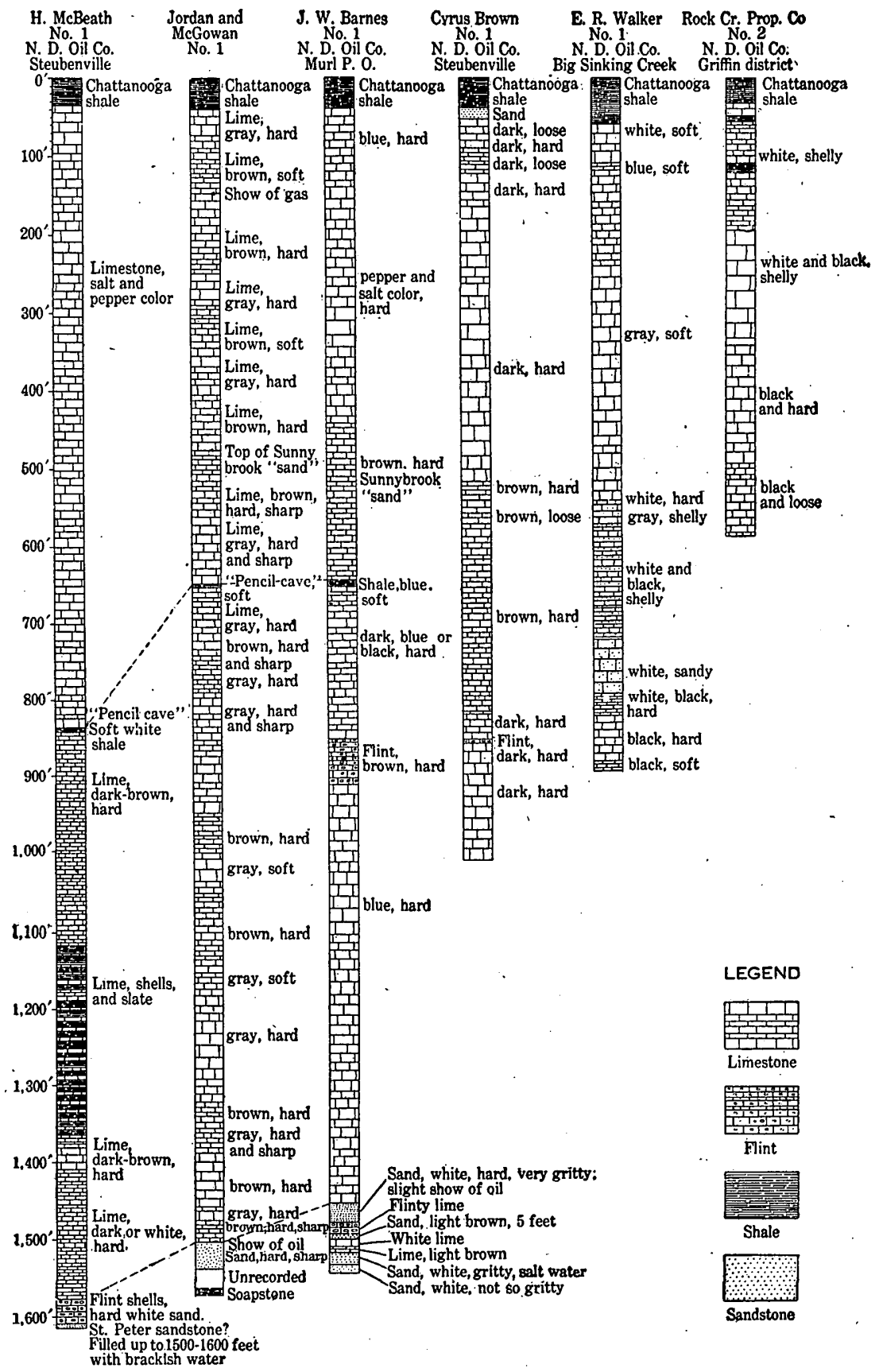

Figure 2.-Sections of deep wells in Wayne County, Ky., showing character of rocks below the Chattanooga ("Black") shale, as reported in the loss by drillers. 
The descriptions given by the drillers are the only information obtainable regarding the character of the rocks encountered in these wells below the Chattanooga ("Black") shale. At the bottom of the McBeath, Jordan \& McGowan, and Barnes wells is a stratum of sandstone, variable in composition and perhaps in thickness. In the Barnes, well this bed is about 100 feet thick and is made up of alternating layers of hard, white, gritty sandstone and layers of flinty limestone. In this well the top of the sandstone is 1,470 feet below the Chattanooga shale, and in the McBeath well its top is 1,600 feet below the Chattanooga. This stratum is identified as the St. Peter sandstone, and the identification is probably correct.

Between the St. Peter (?) sandstone and the Chattanooga shale occurs, except as noted below, a solid mass of limestone, described by the drillers as hard and gray, blue, brown, or pepper and salt in color.

In the McBeath well, however, in the space of 230 to 480 feet above the St. Peter (?) sandstone lies a body of rock described by the drillers as composed of lime shells and slate. This stratum is probably shale with thin limestone layers.

In the McBeath well 770 feet above the St. Peter (?) and in the Jordan \& McGowan and Barnes wells about 830 feet above the St. Peter (?) lies a bed of shale about 10 feet thick that is a rather constant feature in the region. This shale is known to the drillers as the "Pencil cave," because of its tendency to break up into long pencil-like pieces and because it caves badly in the wells. The drillers generally believe they have recognized this shale at many points over a large area in southern Kentucky and northern Tennessee, though it is absent in a number of places. From 100 to 400 feet above this shale and 250 to possibly 600 feet below the Chattanooga shale are zones of creviced limestone, which in the southwest part of Wayne County have locally furnished considerable quantities of oil from two or more horizons. Two of the more well-defined oil zones have been called by drillers the Lower and Upper Sunnybrook "sands."

From the nature of the records it is obviously impossible to make detailed correlations of the limestone revealed by these wells that would be reliable, but a fairly accurate correlation of a broad character is possible. A comparison of the well sections with descriptions of rocks occupying the same general geologic position in other districts in Kentucky and Tennessee shows that the drillers' identification of the St. Peter sandstone is probably correct. As the St. Peter sandstone is of Ordovician age, it follows that all the rocks which have been penetrated below the Devonian belong to the Ordo- 
vician system, except possibly in places a small portion at the top, which may be Silurian. J. B. Hoeing ${ }^{1}$ classifies the first 1,600 feet of rocks below the Devonian shale in Wayne County as follows:

Classification of rocks below the Devonian shale in Wayne County, Ky.

[According to J. B. Hoelng.]

Hudson . Feet.

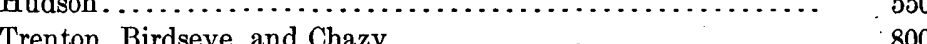

Knox dolomite.

Calciferous at the base.

Foerste ${ }^{2}$ gives the following classification of the Ordovician rocks of eastern Kentucky:

Foerste's classification of the Ordovician rocks of eastern Kentucky.

\begin{tabular}{|c|c|c|c|}
\hline System. & Series. & Formation. & Subdivision. \\
\hline \multirow[t]{2}{*}{ - } & \multirow{4}{*}{$\begin{array}{l}\text { Cincinnatian ( } \mathrm{H} \text { u d s on } \\
\text { River group of former } \\
\text { reports of Kentucky sur- } \\
\text { vey). }\end{array}$} & Richmond. & $\begin{array}{l}\text { Saluda beds. } \\
\text { Versailles bed.. }\left\{\begin{array}{l}\text { Whitewater divi- } \\
\text { sion. } \\
\text { Liberty division. }\end{array}\right. \\
\text { Waynesville bed. }\end{array}$ \\
\hline & & Maysville. & $\begin{array}{l}\text { Arnheim bed. } \\
\text { Mount Auburn bed. } \\
\text { Corryville bed. } \\
\text { Bellevie bed. } \\
\text { Fairmont bed,including Tate layer } \\
\text { in upper half. } \\
\text { Mount Hope bed. }\end{array}$ \\
\hline \multirow{3}{*}{ Ordovician. } & & Eden. & $\begin{array}{l}\text { Paint Lick bed, or Upper Eden. } \\
\text { Million bed.. }\left\{\begin{array}{l}\text { Middle Eden. } \\
\text { Lower Eden. }\end{array}\right.\end{array}$ \\
\hline & & Cynthiana. & $\begin{array}{l}\text { Fulton or Triarthrüs becki layer. } \\
\text { Point Pleasant bed. } \\
\text { Greendale bed. }\end{array}$ \\
\hline & $\begin{array}{l}\text { Jessamine (corresponding } \\
\text { approximately to the } \\
\text { Mohawkian. rocks of } \\
\text { New York). }\end{array}$ & $\begin{array}{l}\text { Lexington. } \\
\text { Highbridge. }\end{array}$ & i \\
\hline
\end{tabular}

The Lexington formation, as classified above, corresponds to the Trenton of former reports of the Kentucky survey, and the Highbridge formation, which is of Stones River and Black River age, corresponds to the Birdseye and Chazy rocks of former reports of that survey. 
UTrich classifies the Ordovician rocks of the Cincinnati dome as follows: ${ }^{1}$

Ulrich's classification of the Ordovician rocks of the Cincinnati domie,

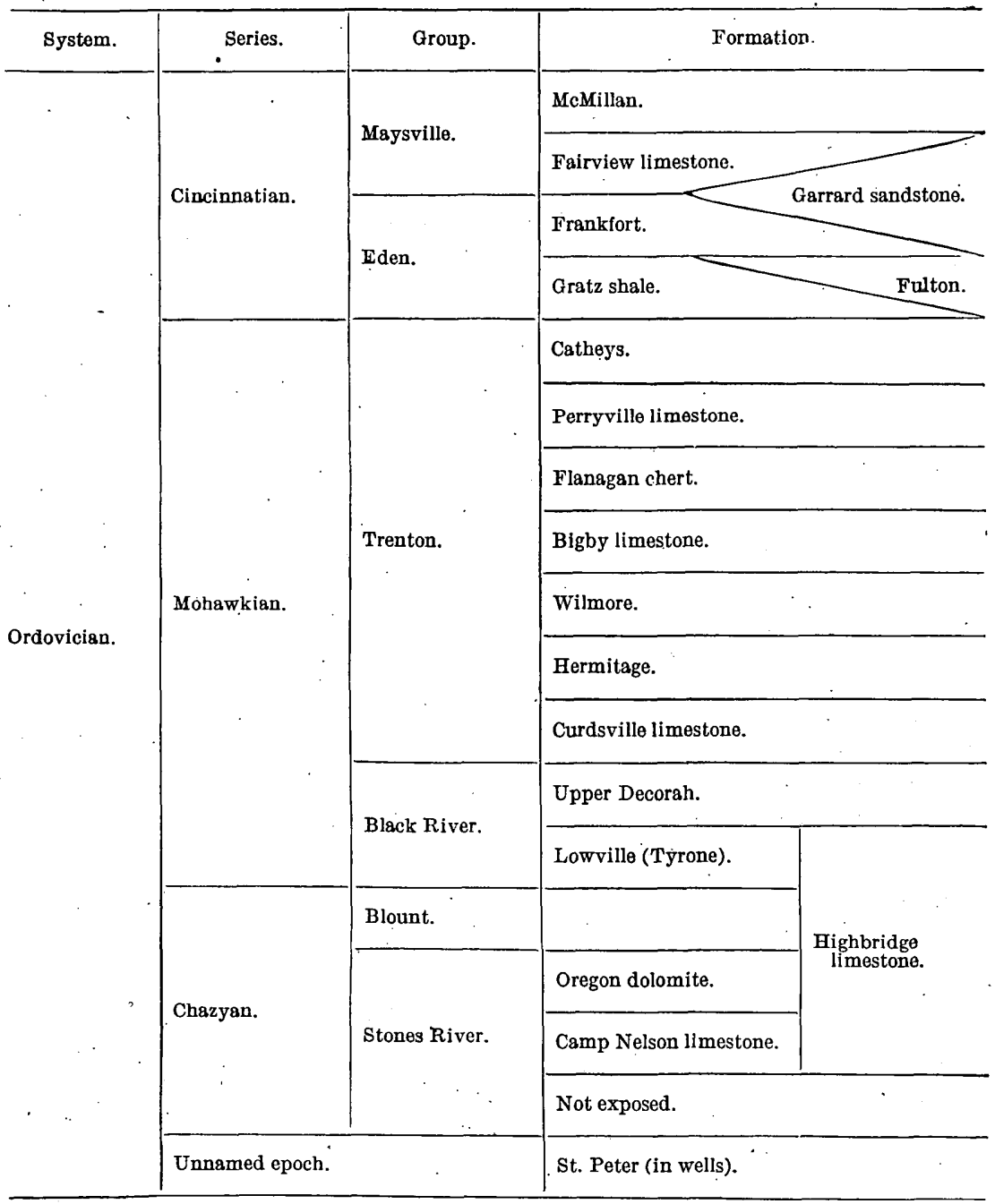

G. C. Matson ${ }^{2}$ gives the following classification and description of the Ordovician rocks where they are best exposed in the Blue Grass region of Kentucky, north of Wayne County:

1 Ulrich, E. O.,, Geol. Soc. America, Bull., vol. 22, p. 608. 1911.

2 Matson, G. C., U. S. Geol. Survey Water-Supply Paper 233, pp. 15-17, 1909. 
Matson's classification of Ordovician rocks in the Blue Grass region.

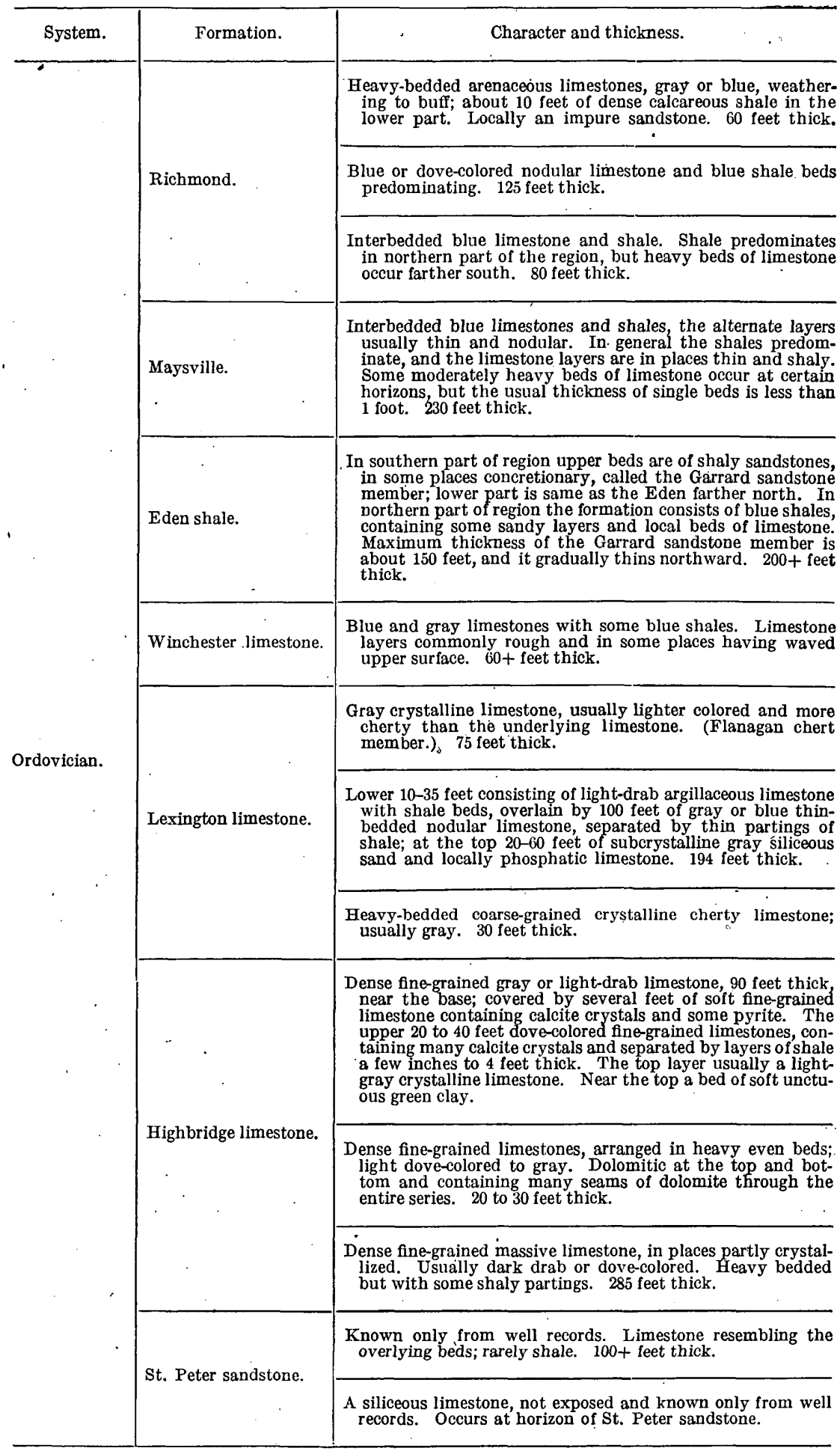


From the above tables it is evident that more or less difference of opinion prevails among geologists regarding the classification of the Ordovician rocks in Kentucky where they are exposed and can be studied in detail. Even if these differences, which are probably more apparent than real, were eliminated, it would be impossible to properly subdivide the Ordovician rocks, as described in the above well records. It seems probable, however, that the thin bed of soft blue shale, called the "Pencil cave" by the drillers, belongs to the upper portion of the Highbridge limestone or at the top of the Chazyan series of Ulrich. Possibly it represents the Curdsville or the Hermitage of Ulrich's section (p. 19) and lies, therefore, near the base of the Trenton group of his classification. The Sunnybrook "sands," mentioned on page 17, probably belong in the middle part of the Lexington formation and are therefore equivalent to a part of the Mohawkian of Ulrich.

The upper part of the limestone below the Chattanooga shale in wells of the western part of Wayne County probably belongs to that part of the Ordovician system which lies below the Cincinnatian series of the tables, whereas in the middle and eastern parts of the county the beds lying immediately below the Devonian may belong to the Silurian system, which in a complete section overlies the Cincinnatian rocks. The Cincinnatian series appears to be absent from Wayne County.

This interpretation of the upper part of the limestone in the wells is based upon its lithologic character, which is entirely different from that of any of the well-recognized divisions of the Cincinnatian series, as that series is predominantly shale with thin layers of limestone. If this interpretation is correct, however, the total thickness, 1;600 feet, is nearly twice that given by Matson-namely, 859 feetfor the limestone from the top of the Winchester to the St. Peter sandstone.

\section{ROCKS EXPOSED.}

\section{SILURIAN 'SYSTEM.}

The Silurian rocks of southern Kentucky and northern Tennessee are thickest in what are thought to have been great. basin areas, which lay both east and west of the Cincinnati anticline at the time of the deposition of the beds. The axis of this arch passes a short distance west of Wayne County with a trend roughly N. $20^{\circ} \mathrm{E}$. In southern Kentucky Silurian rocks are absent along the higher portions of this arch in a belt ranging probably from 40 to 50 miles in width (fig. 3), although it is possible-that they once covered this area, but were removed by erosion before the Chattanooga shale was deposited. The distribution and supposed stratigraphic relations of the Silurian rocks in this region are illustrated in figure 3. 
Two exposures of Silurian rocks on Cumberland River in the northern part of Wayne County near the mouths of Little Cub and Forbush creeks, a short distance west of Mill Springs, are described by Foerste. ${ }^{1}$ These two outcrops practically mark the western border of Silurian rocks on the east side of the Cincinnati anticline and

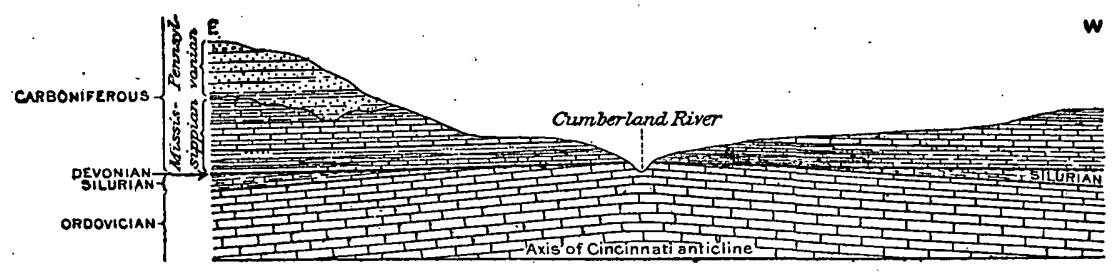

Figure 3.-Diagrammatic section from east to west across the axis of the Cinoinnati anticline in southern Kentucky, showing supposed stratigraphic position of the Silurian rocks on each side of the axis.

are the only known exposures of them in Wayne County. The rocks exposed were described and correlated by. Foerste as follows:

Section of Silurian rocks at mouth of Little Cub Creek, Wayne County, Ky.

Devonian (Chattanooga shale) above.

Silurian system:

Osgood formation:

Feet.

Shale (?), probably greenish clayey (poorly exposed) ...... 9

Limestone, clayey............................ 2

Shale, greenish, clayey........................ $2 \frac{1}{2}$

Clinton formation:

Limestone, layers with large crinoid heads and Whitfidella

subquadrata fossils 3 feet from top................... 19

It seems probable that this outcrop may be traced for a short distance upstream to a point where the easterly dip of the beds takes it below the water level. Westward no other exposures of Silurian rocks àre reported. Sections made by Foerste at Eadsville, Horseshoe Bottom, Swan Bottom, and other localities as far west as Burksville show the Chattanooga shale resting directly on Ordovician strata.

Sections made by E. M. Kindle, of the United States Geological Survey, on Beaver Creek, 3 miles above its mouth, and on Indian Creek, in Clinton County, show the Chattanooga shale resting on Ordovician rocks. From these data it seems probable that the western margin of "Silurian rocks under the surface of Wayne County would be marked by a wavy line trending a little west of south from the mouth of Little Cub Creek. East of this line the Silurian is probably present, although it can not be distinguished from the Ordovician in the well records. 


\section{DEVONIAN SYSTEM.}

\section{ChatTaNooga shale.}

Above the Ordovician and Silurian beds of southern Kentucky lies 20 to 40 feet of black and greenish shale, which is easily recognized both in outcrop and in deep wells over thousands of square miles in Kentucky, Tennessee, and Alabama. In reports of the United States Geological Survey on different portions of the southern Appalachian region this formation has been called the Chattanooga shale, from a typical outcrop at Chattanooga, Tenn., and has been referred to the Devonian system. This reference has been questioned by Ulrich, ${ }^{1}$ who considers the Chattanooga shale to be the basal formation of the Carboniferous system. As the exact geologic age of the Chattanooga shale is of no economic importance, the prevailing usage has been followed, and it is classed as Devonian in this paper.

The Chattanooga shale is called by drillers the "Black" shale, and is used by them as a key rock from which to reckon the position of oil and gas bearing strata. In the region south of middle Kentucky it rarely exceeds 100 feet in thickness, and over large areas of Tennessee and Alabama it ranges from less than 10 feet to probably 30 feet in thickness, though very persistent in occurrence. Northward from middle Kentucky the Devonian rocks thicken abruptly, and the Chattanooga loses its identity in the thickened mass, so that it can not be recognized in deep wells in West Virginia, in eastern Ohio, and western Pennsylvania.

The Chattanooga shale in Wayne County is exposed in a narrow belt a few feet wide along the valley walls of Cumberland River and for a few miles in valleys of Beaver and Otter creeks. An exposure of this shale, on Beaver Creek about 3 miles above its mouth was examined in 1911 by E. M. Kindle, who describes it as follows:

Section of Devonian rocks (Chattanooga shale) at Charles Dow's farm, 1 mile above Beaver Creek mill on Beaver Creek, Wayne County, Ky.

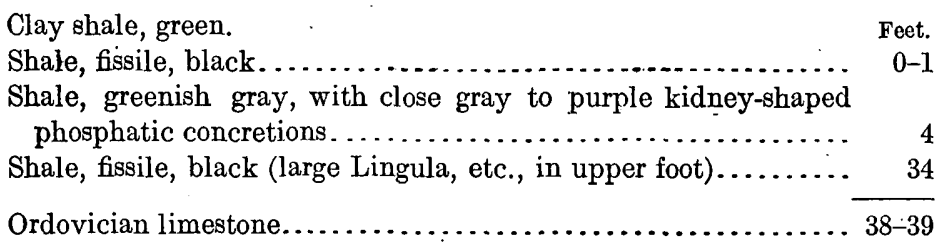

The 4 feet of greenish clay shale with phosphate nodules may represent the green shale which has been called Maury shale in Tennessee.

Practically all the deep wells drilled in Wayne County to the horizon of the Chattanooga shale have found it between 10 and 40 feet in thickness. It is a soft, black, petroliferous and carbonaceous 
shale, easily recognized by drillers, who note it in well logs as the "Black shale" or the "Devonian shale."

The Devonian system in the northern part of the coal field of eastern Kentucky includes the Boyle limestone of Foerste, which is equivalent, in part at least, to the "Corniferous" of previous Kentucky and Ohio reports. This limestone is the oil-bearing bed in the Ragland field of Bath County, the Irvine field of Estill County, the Campton field of Wolfe County, and the large gas field near Rothwell, in Menifee County. In Wayne County it is absent in outcrop and has not been recognized in records of deep wells. Its nearest known exposure is in the middle part of Rockcastle and Lincoln counties.

CARBONIFEROUS SYSTEM.

GENERAL CHARACTER OF THE ROCKS.

The general character of the Carboniferous rocks exposed in Wayne County is shown graphically in figure 4.

The Mississippian series is separated from the Pennsylvanian by an unconformity, which represents a long interval between the deposition of the uppermost Mississippian beds and that of the lowermost Pennsylvanian beds which directly overlie them. This means that the deposition of sediments on the old sea bottom did not continue uninterruptedly from the Mississippian directly into the Pennsylvanian; but that at the end of Mississippian time this region was raised above sea level. The land surface thus formed was exposed to erosion by streams, wind, and the other agencies that are to-day reducing the present surface. After erosion had gone on for a long time the region was again submerged beneath a shallow epicontinental sea and the deposition of sediments of Pennsylvanian age began. The plane of contact between these two series is therefore an ancient land surface which was more or less modified by wave action when it was slowly submerged beneath the sea. The strata of these two series of rocks do not lie parallel, the lowest bed of the Pennsylvanian series having been deposited as sediment on the eroded surface of the slightly folded beds of the Mississippian series. For this reason the dip of the coal and other prominent beds of the Pennsylvanian can not be used as a guide in determining the dip of the oil-bearing beds of the Mississippian series. Other unconformities of less magnitude may be present within both the Pennsylvanian and the Mississippian series. The few facts which suggest the possible presence of one or more unconformities in the Mississippian will be pointed out later.

\section{MISSISSIPPIAN SERIES.}

SUBDIVISIONS.

In figure 4 the Mississippian series is shown to be divided into three general stratigraphic divisions. The lowest division, consisting principally of shale with a few thin beds of limestone, has a thickness 
of 150 to 260 feet. This portion has generally been called Waverly formation in the Kentucky Survey and other reports on the region, and that name will be used in this report. Foerste correlates the lower part of the "Waverly" formation, which he called the Linietta

\begin{tabular}{|c|c|c|c|c|c|c|c|}
\hline 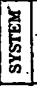 & 㐘 & 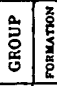 & MNOR DIVISIONS & 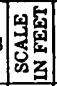 & $\underset{\text { BECTION }}{\text { COLUUNAR }}$ & $\begin{array}{l}\text { INICRNESS } \\
\text { IN FEET }\end{array}$ & GENERAL CHARACTER \\
\hline \multirow{4}{*}{\multicolumn{2}{|c|}{ 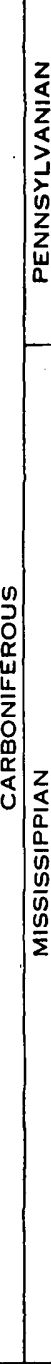 }} & 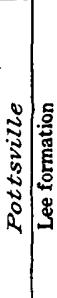 & $\begin{array}{c}\text { Rockcastle } \\
\text { conglomerate } \\
\text { member }\end{array}$ & \multicolumn{2}{|c|}{100} & $0 \cdot 400 \pm$ & $\begin{array}{l}\text { Coarse brown, very massive conglomeratic sandstone. } \\
\text { Caps few of highest hills } \\
\text { Alternating massive to thin-bedded sandstone and } \\
\text { yellowish to brown sandy shale containing two or more } \\
\text { coal beds, locally of minable thickness. Hillsides: }\end{array}$ \\
\hline & & 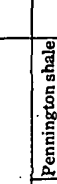 & $\left\{\begin{array}{l}\text { UNCONFORMITY } \\
\text { Spann } \\
\text { limestone member }\end{array}\right.$ & $\left\{\begin{array}{c}250 \\
300 \\
350\end{array}\right.$ & 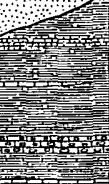 & $0.250 \pm$ & $\begin{array}{l}\text { Predominantly soft green and yellow clay shale, } \\
\text { containing thin limestone beds. and one massive cherty } \\
\text { geodic limestone } 6 \text { to } 12 \text { feet thick. Toward the top } \\
\text { the shale is red and contains thin beds of shaly sandstone } \\
\text { and a few thin beds of yellowish limestone. } \\
\text { Massive dark cherty geodic limestone. }\end{array}$ \\
\hline & & 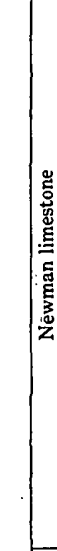 & $\begin{array}{c}\text { Sandstone } \\
\text { member }\end{array}$ & $\left\{\begin{array}{c}400 \\
450 \\
550 \\
500 \\
600 \\
650 \\
700 \\
750\end{array}\right.$ & 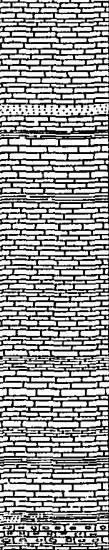 & 462 & $\begin{array}{l}\text { Dark-blue and gray limestones, very hard, slightly } \\
\text { bituminous in places, fossiliferous. } \\
\text { Shaly thin-bedded calcareous sandstone; thinner } \\
\text { toward north but very persistent. } \\
\text { Light-gray and bluish limestones, oolitic in lower portion. }\end{array}$ \\
\hline & $\frac{\frac{2}{2}}{\frac{\pi}{n}}$ & 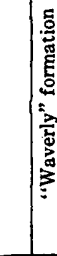 & \begin{tabular}{|l} 
Cherty limestone \\
("Stray sand"?) \\
Beaver Cr.oil"sand" \\
(cherty limestone)"
\end{tabular} & $\begin{array}{l}\cdots \\
1,050 \\
\cdots, 100\end{array}$ & 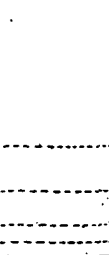 & 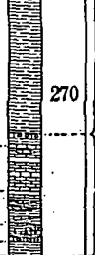 & $\begin{array}{l}\text { Dark-bluish (when wet), calcareous sandy shale, } \\
\text { very compact and homogeneous. Appears to be } \\
\text { somewhat scantily fossilfiferous. } \\
\text { Soft green clay shales, containing thin beds of dark-gray, } \\
\text { brown, and greenish cherty geodic. siliceous limestone, } \\
\text { which are frequently petroliferous. }\end{array}$ \\
\hline$D E$ & Evo & NIAN & N Chattanooga shal & & & 25 & Black shale \\
\hline
\end{tabular}

FigURE 4.-Generalized section of rocks exposed in Wayne County, $\mathrm{Ky}$.

clay, with the New Providence shale of the Indiana Survey. This correlation agrees in part with that of Kindle, who in a section measured by him on Beaver Creek, Wayne County, Ky. (see p. 27), considers the first 178 feet of strata above the Chattanooga shale to 
be the equivalent of the New Providence shale of the Indiana Survey. This section of Kindle appears to be equivalent to the Parnell section given below, except that it includes at the top a sandstone which probably lies above the rocks of the Parnell section.

The middle division of the Mississippian series consists almost entirely of limestone with a few thin beds of soft shale and a thin, fairly persistent bed of sandstone and has a total thickness of about 500 feet. It represents the beds in eastern Kentucky and farther south that have been described in reports of the United States Geological Survey as the Newman limestone. It is the age equivalent, in part at least, of beds in western Kentucky which have been classed as St. Louis, Ste. Genevieve, and Chester. The upper division of the Mississippian, ranging from a feather edge to probably 260 feet, is largely red and green shale with thin beds of both limestone and sandstone, and in the folios of the United State Geological Survey has been called the Pennington shale.

$$
\text { "WAVERLY" FORMATION. }
$$

Lithologic character.-The general character of the "Waverly" formation is brought out by the following two sections, which are west of any exposed in Wayne County:

Section of the "Waverly" formation about 2 miles southwest of Parnell, Wayne County, $K y$., on north side of Beaver Creek valley.

Top of section begins about 40 feet below top of terrace.

1. Limestone, probably "stray oil sand," dark gray, with Ft. in. geodes................................ 15

"Waverly" formation:

2. Shale, dark blue (when wet), calcareous, veryoarenaceous in places.................................. 150

3. Limestone, dark blue (weathers red), containing quartz geodes..................................... 2-3

4. Shale, brown, arenaceous and calcareous........... 8

5. Limestone, coarsely crystalline, gray; weathers reddish brown, exposing many fragments of small crinoid stems (two layers with 4 feet of shale between)..... 7

6. Concealed.................................. 2

7. Limestone, dark to reddish gray, very tough and compact; weathers rusty colored...................... 3

8. Shale, dark to bluish, very arenaceous and bituminous. . 3

9. Limestone layers, 2 to 3 feet thick, dark steel-gray, fine to coarsely crystalline; weathers reddish to brown.....

10. Limestone, very arenaceous and bituminous, poorly exposed............................... 5

11. Limestone, light bluish gray, containing much reddish fossiliferous chert; weathers brown to rust colored.... 8

12. Shales, soft, green, argillaceous................. 6

13. Limestone, thin lenses, very fossiliferous, reddish, siliceous ....................................

14.. Shale and limestone, soft, green, argillaceous, containing a few 1 to 2 inch layers of limestone, fossiliferous. . 
15. Limestone (Beaver.Creek oil "sand"), cherty, carrying geodes, very irregular, massive layers 2 to 5 feet thick in two sections separated by 3 feet or less of soft, green, Ft. in. argillaceous shale........................ 14

16. Shale and limestone, light bluish, green, with 1-inch inclusions, fossiliferous limestone similar to No. 14... 10

$268 \quad 6$

Chattanooga shale (Devonian):

17. Nodules, phosphatic, from one-half to 3 inches in diameter, in light-blue to greenish clay ................

1.8. Shale, black, fissile, petroliferous and carbonaceous.... Concealed below drainage (?).

Section of the "Waverly" formation oǹ Beaver Creek 3 miles above its mouth and 1 mile above Beaver Creek mill.

"Waverly" formation:

[By E. M. Kindle.]

Drab-colored, locally shaly sandstone, with geodes.......... $\quad 40$

Gray crinoidal limestone............................ $\quad 15$

Greenish-gray highly calcareous shale................ 83

Bluish-gray crinoidal limestone with some interbedded green

shale....................................... 10

Green shale with a few 2 to 3 inch bands of crinoidal limestone. $\quad 48$

Green clay shale............................. $\quad 22$

Chattanooga shale.

A comparison of the Beaver Creek mill and Parnell sections shows considerable local variation both in the thickness and in the character of the "Waverly" formation. The details of this formation as revealed by well records suggest that the changes shown by the exposed sections are characteristic of this formation in the county. The Parnell section shows 60 feet of soft green shale at the base of the formation inclosing 14 feet of cherty geode-bearing limestone, the top of which is less than 30 feet above the Chattanooga shale. This limestone, which is the Beaver Creek oil "sand," is absent in the Beaver Creek mill section. Above the green shale in the Beaver Creek mill section lies 10 feet of crinoidal limestone and green shale, which in the Parnell section appears to be represented by 48 feet of limestone and brown and dark-bluish shale. In the Beaver Creek mill section this limestone is overlain by 83 feet of greenish-gray highly calcareous shale, corresponding to 150 feet of dark-blue (when wet) shale of the Parnell section. In both sections 15 feet of crinoidal limestone occurs at the top. In the Parnell section the rocks overlying this limestone were concealed at the top of the valley wall and their character could not be determined. The total 
thickness of the "Waverly" formation in these two sections ranges from 178 to 273 feet, the thickening being toward the east. A very scanty collection of fossils from the Parnell section suggests to George H. Girty that the beds may be in part at least of Keokuk age. This suggests the possibility that the variation in thickness and character of the strata in Wayne County may be due in part to unconformities, so that rocks of Burlington and Kinderhook age, which in western Kentucky lie between the Chattanooga shale and the Keokuk limestone, may be absent or only partly represented here. These questions of exact correlation, however, must be settled by more detailed work than could be given to them for the present report. The "Waverly" formation is of economic importance because it contains the principal oil and gas bearing beds of Wayne County.

Oil sands.-Most of the oil in this district is found in a cherty geode-bearing limestone (No. 15 of the Parnell section) called by drillers the Beaver Creek "sand." In well records the Beaver Creek "sand" is shown to vary considerably in distance above the top of the Chattanooga ("Black") shale. In many wells it is as much as 60 feet above the Chattanooga shale, but in most places where productive it appears to be only a few feet above that shale, from which it is separated by light-green and blue clay shales. The writer suspects that in many places where the Beaver Creek "sand" is reported by producers to be "high" above the Chattanooga shale, the true Beaver Creek "sand" (No. 15 of the Parnell section) may be absent, as in the Beaver Creek mill section, and that the limestones Nos. 9 to 11, inclusive, of the Parnell section or No. 4 of the Beaver Creek mill section may have been mistaken for it. This mistake could easily occur, for the character of the shale in which these limestones are embedded is identical, and the differences in the character of the limestones would be very difficult to distinguish in drilling. It is equally probable that the varying interval and local absence of the sand are due to deposition on an irregular and slowly subsiding surface having low land barriers and islands. It is obvious that in such a slowly sinking area each successive stratum would have a wider extent than the preceding one, that it would be absent where land areas existed at the time of its deposition, and that its distance above the surface existing prior to the beginning of submergence (in this case the Chattanooga shale) would vary from place to place. The name Beaver Creek "sand" appears to have been somewhat indiscriminately applied to any single limestone bed near the base of the "Waverly" formation, especially if it contained oil. Plates I and II show the appearance of the porous portion of the Beaver Creek "sand" where it is oil bearing. 

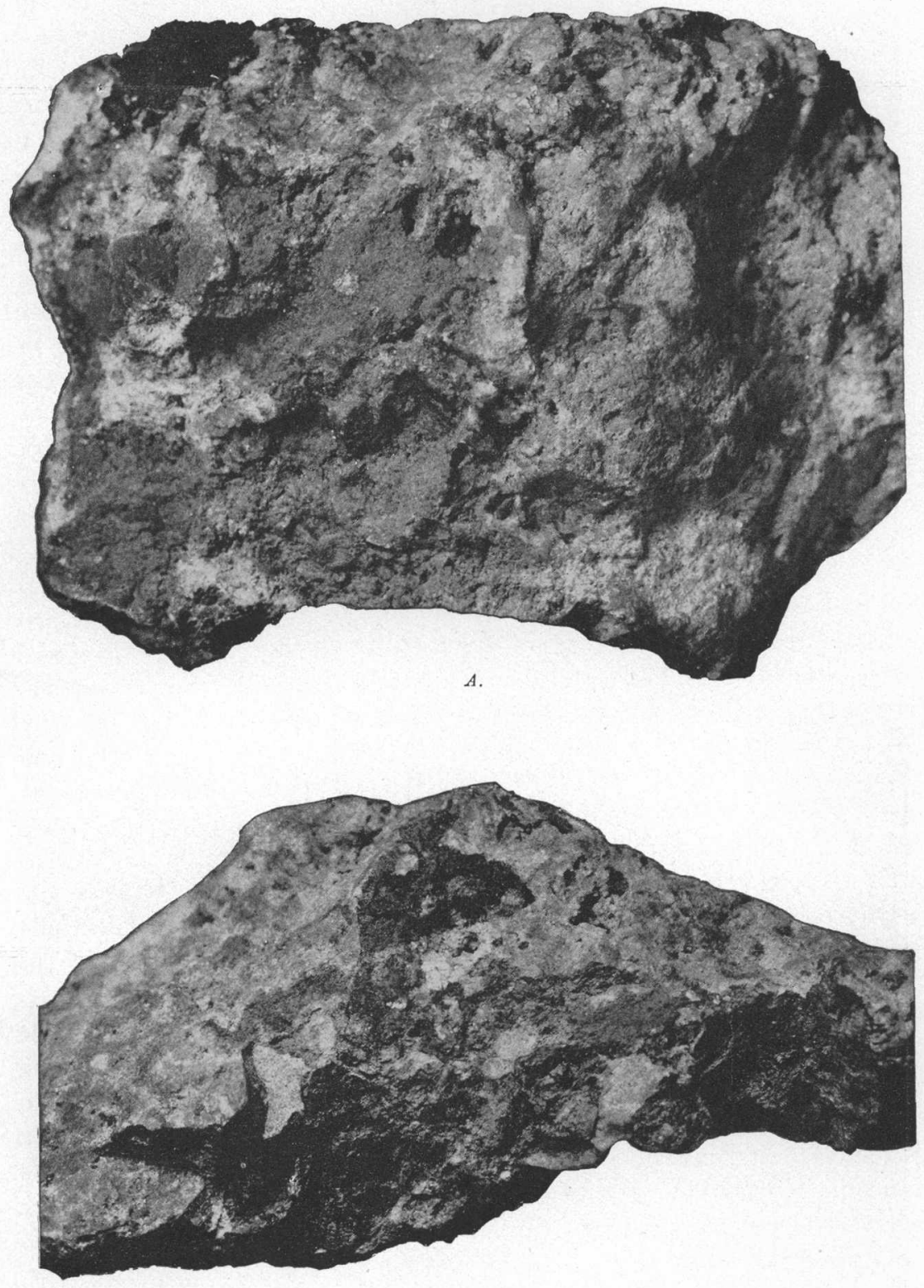

B.

SPECIMENS OF BEAVER CREEK OIL "SAND" FROM WAYNE COUNTY, KY.

$A$, From the Griffin field; $B$, From the Mount Pisgah field 


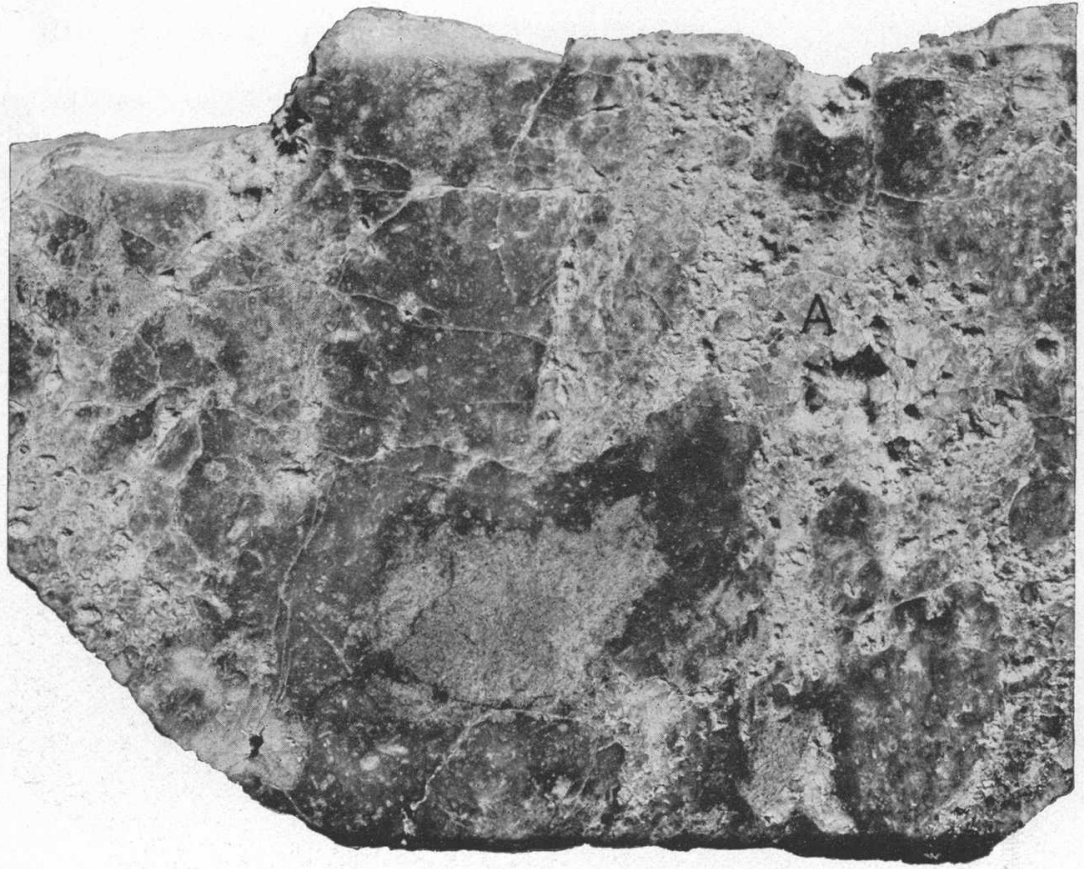

$A$.

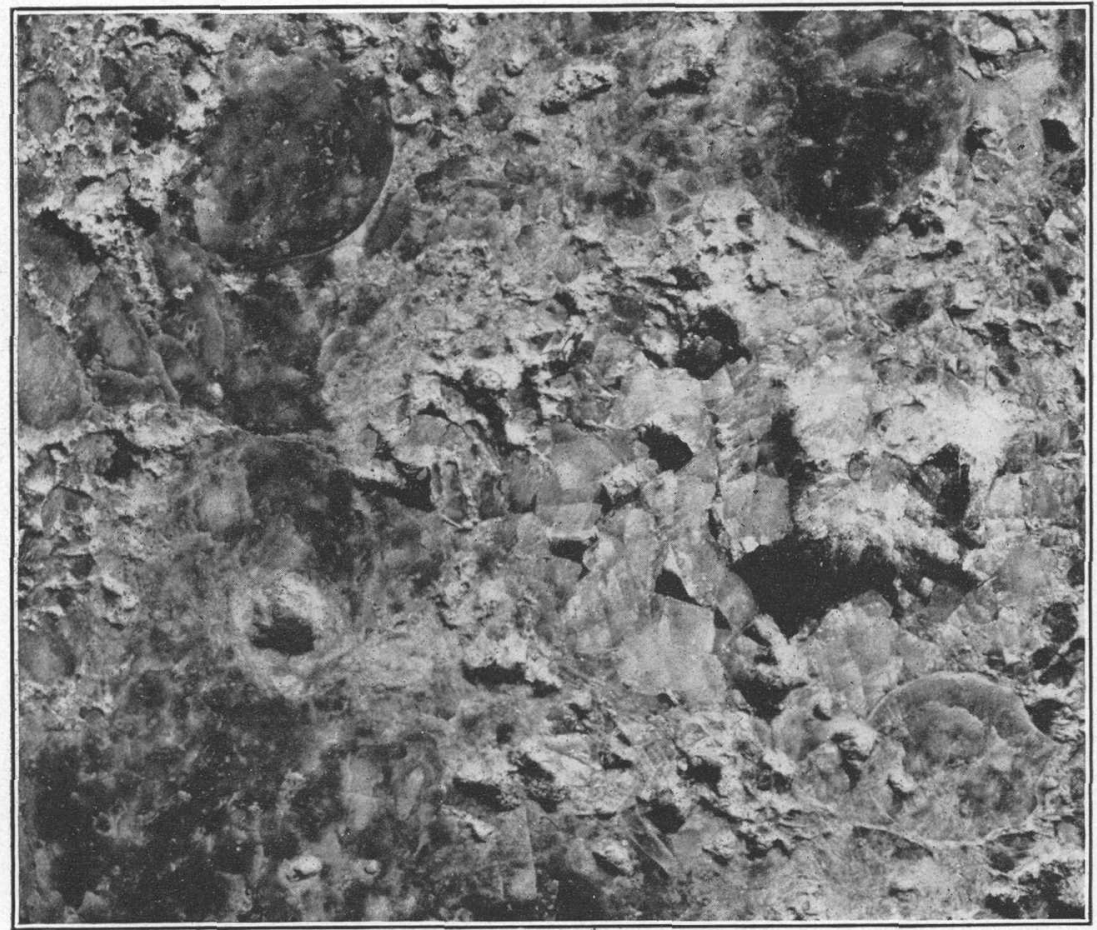

$B$.

SPECIMENS OF BEAVER CREEK OIL "SAND" FROM WAYNE COUNTY, KY 
Near the top of the "Waverly "formation occurs a cherty geodebearing limestone, ranging from 10 to probably 30 feet in thickness, in which oil and gas have been found at a number of places in Wayne County. This is usually identified by drillers as the Corder or "Stray sand." More detailed descriptions of these beds will be given in the discussion of the oil fields.

\section{NEWMAN LIMESTONE.}

The rocks grouped as the Newman limestone in figure 4 (p. 25) consist of 450 to 550 feet of massive to thin-bedded limestone, in which occur a few thin beds of soft, green, blue, and red clay shales, and one thin persistent bed of shaly calcareous sandstone. The following sections are fairly typical of this formation:

Section of the Newman limestone and underlying beds on the north side of. the canyon of Elk Spring Creek at the falls and water mill, $1 \frac{1}{2}$ miles west of Monticello.

[The top of the section begins on the road 30 feet below the top of the terrace on the north side of the creek near the waiting trough.]

Lower part of Newman limestone; probably of Keokuk age:

1. Limestone, massive, dove-colored, very brittle, fractures Feet. "crinkly" ......................... 8

2. Limestone, rotten, whitish; very argillaceous............ 3

3. Shale, light bluish-green, soft, very argillaceous......... 3

4. Limestone, very dark blue, hard, coarse grained. ....... 2

5. Concealed................................. 2

6. Limestone, dark steel-gray, coarse, crystalline, very fossiliferous, thin, irregular bedded, cliff making.......... 11

7: Limestone, crystalline, almost black to dark steel-gray, growing lighter toward top. ......................

8. Limestone, steel-gray, very hard, weathers reddish to yel-

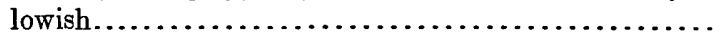

9. Shale, dark blue (when wet), coarse, compact, calcareous, containing a few 1 to 4 inch layers of dark-blue shaly limestone.

10. Limestone, very massive, hard, compact, brownish blue, cherty, forms top of falls..................... 9 .

11. Concealed

12. Limestone, massive, steel-gray, very hard, compact, noncrystalline................................... 3

13. Limestone, gray, thin bedded, soft, shaly .......... 2

"Waverly" formation (?):

14. Limestone, dark gray, compact, thin, irregular bedded,

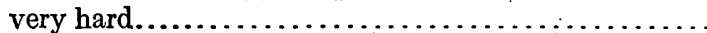

15. Limestone, reddish gray or brown, massive, cherty, con-

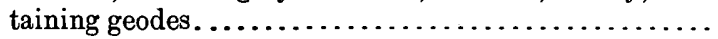

16. Shale, dark, bituminous, very soft. .................. $3-4$

17. Shale, dark, coarse, calcareous, and arenaceous........ 5 To creek bed below falls. 
Limestone No. 15 of this section is thought to be equivalent to limestone No. 1 of the Parnell section, but this correlation is by no means certain. The rocks of this section have been tentatively identified by George H. Girty from insufficient fossil evidence as being probably of Keokuk age.

Section of the Newman limestone from Elk Spring Creek up Monticello Hill 1 mile west of Monticello.

Top of section.

Feet.

1. Limestone, light colored, brittle, argillaceous........... 12

2. Limestone, massive, yellowish and brownish blue........... 12

3. Limestone, poorly exposed in reddish clay.............. 10

4. Limestone, reddish and flesh-colored layers from 1 to 3 feet in thickness.......................................

5. Limestone, one layer dark, steel-gray, very hard and tough, the remainder brown, very hard. .....................

6. 'Clay (probably residual) with thin layers of limestone.......

7. Limestone, reddish, hard, tough, crystalline, weathers brown.

8. Limestone, dark brown to gray, containing brown and black particles; cliff making

9. Limestone, flesh-colored, fossiliferous layers from 2 to 4 feet

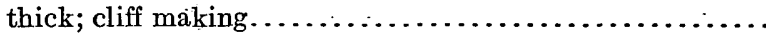

10. Limestone, crystalline, flesh-colored and very fossiliferous...

11. Limestone; massive, flesh-colored, crystalline, containing many large crinoids; cliff making. ....................

12. Concealed.

13. Limestone, massive, light colored; middle portion weathers greenish, remaining portion blue; fossiliferous; cliff making.

14. Limestone, light-colored, weathers blue, crystalline, shows mass of fossils on weathered surface....................

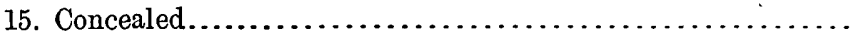

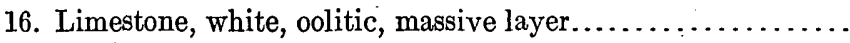

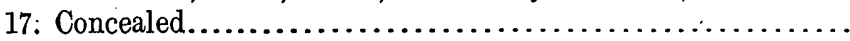

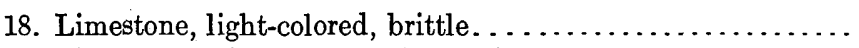

19. Limestone, with small geodes, flesh-colored...............

20. Limestone, dark bluish, filled with minute calcite crystals....

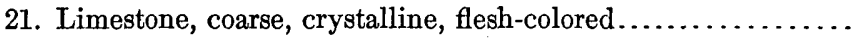

22. Limestone, dark and bluish, breaks in cubical blocks........

23. Limestone, very light gray to whitish, coarse grained, showing distinct joints.

24. Limestone, dark, crystalline, close grained, 'fossiliferous, numerous crinoids.

25. Limestone, peculiar bluish brown, very hard and brittle, fractures easily; irregular, somewhat cubical blocks.......

26. Limestone, tough, light gray to flesh-colored................

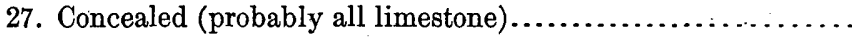

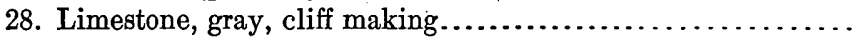

29. Limestone, thin bedded, cherty, pinkish, crystalline, cliff

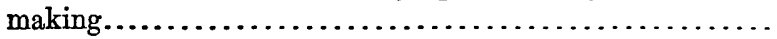

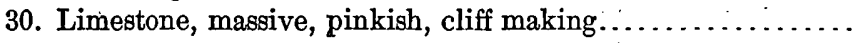

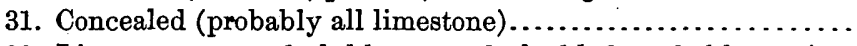

32. Limestone, very dark blue, evenly bedded, probably equivalent to No. 4 of the Monticello section. 
33. Limestone, partly concealed, dark, steel-gray, thin bedded;

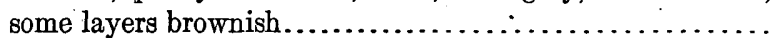

Feet.

7

34. Limestone, weathering rusty yellow, very massive..........

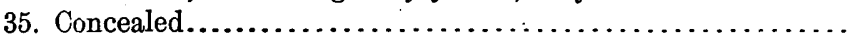

36. Limestone, greenish, very thin bedded, looks almost like coarse shale in places..............................

37. Concealed below by bed of Elk Creek.

No. 34 of the above section appears to be equivalent to No. 1 of the Elk Spring Creek section given above.

\section{Section of the Newman limestone near Parmleysville. ${ }^{1}$}

42. Limestone; flesh-colored to dark blue

43. Limestone, hard, dun-colored, banded

44. Limestone, dense blue bands interbedded with fine shaly limestone.

45. Limestone, shaly, pale bluish gray, abundant fucoids........

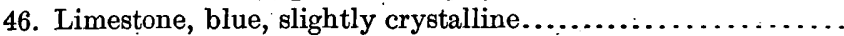

47. Limestone, grayish blue, slightly crystalline...............

48. Limestone, blue-gray, pink, in places bituminous.............

49. Limestone, very hard, dark blue, fossiliferous, shaly toward

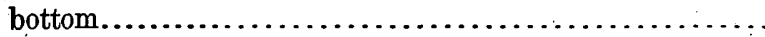

50. Limestones, mostly hard, thin bedded, bluish to gray........

51. Limestone, shaly, greenish clay pebble-like inclusions........

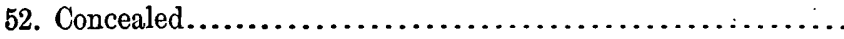

53. Limestones, bluish, somewhat thick bedded................

54. Sandstone, thin bedded, impure, curly ripple marked, fossiliferous: ........................................

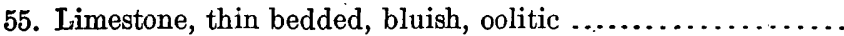

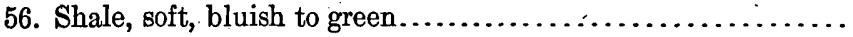

57. Limestone, slightly oolitic, gray to pale blue, calcitic .......

58. Limestone, rough, subgranular, slightly fossiliferous, pale blue,

reddish toward base............................... 7

$(0$

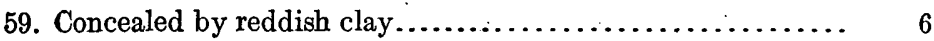

60. Limestone; suboalitic layers 12 to 14 inches, crystalline at top.. $\quad 15$

61. Limestone, coarse, dark blue to reddish, hard, very fossiliferous $\quad 6$

62. Shale, soft, olive-green, partly concealed at bottom........ 6

63. Limestone, massive, buff with reddish streaks, containing

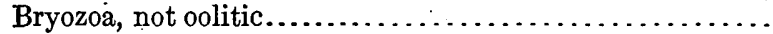

64. Limestone, bluish gray, oolitic, top foot fossiliferous..........

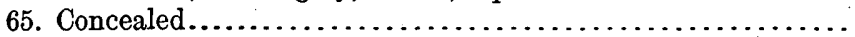

66. Limestone, massive layer, calcitic inclusions:.............

67. Limestone, fine grained, noncrystalline, bluish, layers about

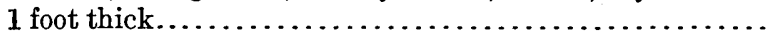

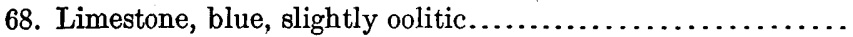

69. Limestone, creamy gray, weathers in thin shaly layers, slightly

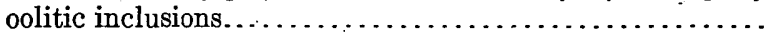

70. Limestone, massive, light gray, oolitic................

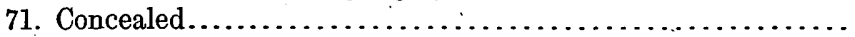

72. Limestone, light gray, oolitic, fossiliferous, lower blue layers

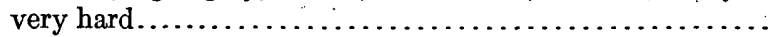

To water below dam at Parmleysville.

1 This section includes the exposed portion of the Newman limestone on the Parmleysville-Monticello county road from below the dam at Parmleysville to the top of the hill above the power house on the Bell property. (The upper part of this section is given on p. 32.)

$29755^{\circ}-$ Bull. $579-14-3$ 
A comparison of this part of the Parmleysville section with that of the Monticello Hill section suggests strongly that limestone No. 64 of the Parmleysville section is equivalent to limestone No. 16 of the Monticello Hill section. The fossils obtained from this part of the Newman limestone suggest to G. H. Girty that beds 55 to 64 , inclusive, belong within the Ste. Genevieve limestone. On the stratigraphic evidence No. 54 appears to be the same as the Hartselle sandstone member of the Bangor limestone of Alabama and Tennessee, and the Hartselle sandstone member in turn may be equivalent to the Cypress sandstone of the Ohio River section. The balance of this section overlying the sandstone, forming bed 54, appears to Girty to be equivalent to the upper part of the Chester group farther to the west, but the Tribune and Birdsville formations of that group can not at present be differentiated here. All these correlations, being based on slight fossil evidence, are more or less tentative. Detailed work in this district will doubtless supply sufficient data for a much closer correlation of these rocks with those of western Kentucky and adjacent portions of Illinois and Indiana.

PENNINGTON SHALE.

Lithologic character.-The Newman limestone is overlain by red and green clay shales ranging in thickness from a feather edge to 250 feet, in which are included a few thin beds of limestone and sandstone. The top of this formation is marked by the unconformity already described as separating the Mississippian from the Pennsylvanian rocks. To this unconformity is due the great variation in thickness of the Pennington in Wayne County.

The following section of the Pennington shale is a continuation of the section given above (p. 31) of the Newman limestone near Parmleysville:

Section of the Pennington shale near Parmleysville.

Pennsylvanian:

1. Sandstone, thin bedded, gray ................. $\quad 17$

Pennington shale:

2. Shale, soft red clay........................... í

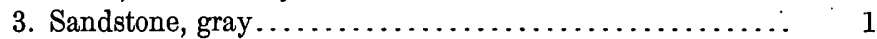

4. Shale, soft, red............................. 10

5. Concealed................................... 7

6. Shale, soft, red.................................. 6

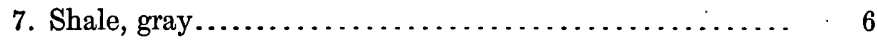

8. Shale, soft, red............................ 17

9. Concealed................................. 22

10. Shale, soft, red........................... 20

11. Shale, soft, light blue.......................... $\quad 6$

12. Shale, red, soft.............................. 5

13. Shale, coarse, reddish, micaceous.................. 6

14. Shale, thin, curly, stiff, micaceous................. 4

15. Sandstone, thin bedded to heavy, gray............... 15 
16. Concealed..................................... 3

17. Shales, soft, green and blue clay $\ldots \ldots \ldots \ldots \ldots \ldots \ldots \ldots . .7$

18. Shale, soft, green, calcareous...................... 6

19. Concealed.................................. 1

20. Sandstone, thin-plated, greenish, probably calcareous.... 3

21. Concealed (probably green shale) $\ldots \ldots \ldots \ldots \ldots \ldots \ldots \ldots . \quad 10$

22. Shale, soft, green........................ 10

23. Shale, soft, bluish, calcareous, weathers like shaly sandstone.................................. 3

24. Limestone, thin bedded, blue, very fossiliferous........ 2

25. Concealed.................................. 3

26. Shale, soft, greenish.......................... $\quad 15$

27. Shale, marly, greenish........................ 2

28. Chert and calcareous shale and thin sandstones......... 1

29. Shale, black............................... 6

30. Shale, green, soft.............................

31. Limestone, buff to blue........................ 3

32. Shale, soft, greenish, with 1-inch calcite veins........ 10

33. Limestone, calcitic........................... 3

34. Shale, soft, green........................... 2

35. Limestone, Spann member, two layers dark, rusty, massive, finely crystalline, containing chert and numerous quartz geodes................................ 11

36. Shale, green, soft............................ 3

37. Limestone, bluish........................... 2

38. Shale, soft, yellow........................... 3

39. Shale, soft, green ................................ 3

40. Limestone, badly weathered, yellowish, impure......... 2

41. Shale, soft, olive-green, clay..................... 8 Top of Newman limestone.

Thickness.-The Pennington shale is generally thickest in the southern part of Wayne County, along Little South Fork, and probably toward the south and west. It appears to be thinnest and in places is entirely absent in the vicinity of Oil Valley and northeast of that place. The average thickness of the formation is probably less than 90 feet and in many places the top of the Newman limestone is separated from the Pennsylvania sandstone above by less than 50 feet of thin layers of limestone in green shale. The Pennington shale seems to be equivalent in age to the upper portion of the Chester group. Its exact time equivalent in' western Kentucky and southern Illinois and Indiana is not known, but both fossil and stratigraphic evidence suggest that it may belong largely if not wholly within the Birdsville formation, the uppermost formation of the Chester group.

Spann. limestone member.-Aside from the green shale in the lower portion of the Pennington and the red shale toward the top, the most characteristic bed is the limestone to which the name Spann limestone member is given in this report, from typical exposures at the town of that name in Wayne County. This bed is a massive 
geode-bearing cherty limestone, ranging from 3 to 15 feet in thickness, the top of which lies from 20 to 35 feet above the base of the formation. This limestone is very persistent throughout Wayne County; and is easily recognized wherever exposed by the numerous quartz geodes which protrude from the exposed edges of the limestone. The limestone resists weathering much better than the soft red and green shales in which it is embedded and is in many places exposed as a low cliff around the sides of the hills. This bed has been used as the key stratum for determining the dip of the rocks in the southeastern part of the Monticello quadrangle, as shown on Plate III.

\section{PENNSYLVANIAN SERIES.}

Pottsville group.

LEE FORMATION.

Lithologic character.-Above the Pennington shale and at the surface of the higher hills lie from a thin film to 400 feet or more of Pottsville rocks, known as the Lee formation. These rocks are sandy shales, weathering brown to reddish; massive sandstones; a few coal beds; and, at the top from 20 to perhaps 60 feet of conglomerate. These rocks are generally poorly exposed because of the accumulation of sandstone bowlders and débris upon the hillsides. In the field work for this report very little attention was given to these beds because, as they cap the higher hills, they have no geologic value in the study of the oil and gas fields. The measurements obtained of them were few and very incomplete: The generalized section of these rocks as shown in figure 4 ( $p .25$ ) is therefore largely hypothetical and will doubtless be greatly modified by future detailed work in this region.

Rockcastle conglomerate member.-The conglomerate which caps a few of the highest hills appears to be equivalent to the Rockcastle conglomerate of the Standingstone quadrangle of Tennessee and the London quadrangle of Kentucky. It is generally composed of 5 feet or more of white quartz pebbles and coarse sand at the base and a similar layer about 30 to 35 feet above the base, the remainder of the bed being composed of very coarse brownish sandstone without bedding planes. This conglomerate is exposed as a vertical cliff on the tops of the highest hills, only a few acres being present at any one spot. It forms the cap rock of Pilot Knob, 3 miles west of Monticello, where it reaches an altitude of over 1,600 feet and is probably as much as 100 feet in thickness.

\section{STRUCTURE.}

\section{GENERAL FEATURES.}

Wayne County is situated on the western edge of the Appalachian coal field, which in Kentucky lies between the Cincinnati anticline and Cumberland (Pine) Mountain. The geologic structure of this 


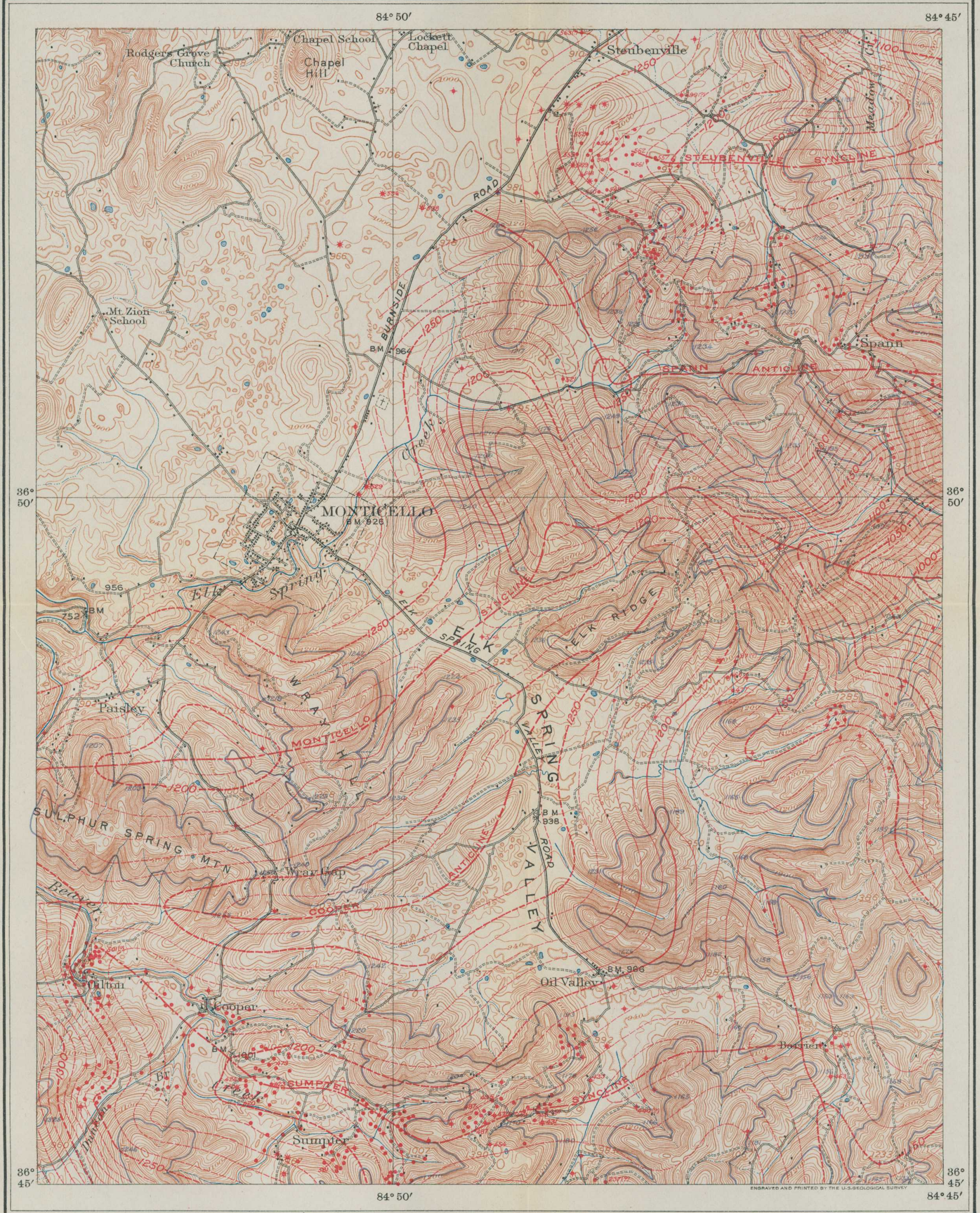

TOPOGRAPHIC MAP OF THE SOUTHEASTERN PART OF THE MONTICELLO QUADRANGLE, KENTUCKY SHOWING LOCATION OF OIL AND GAS' POOLS, DEEP WELLS, AND OUTOROP OF AND STRUOTURE CONTOURS
ON THE SPANN LIMESTONE MEMBER OF THE PENNINGTON SHALE

Seale $\frac{1}{62,500}$ 3 Miles

Outcrop of the Spann limestone member Numbers represent altitude of limestone at
Contours on the top of the Spann limestone member Datum is mean sea level

\section{WELL SYMBOLS}

Oil well

Gas well

Show of oil

Show of oil and ga Show of gas Dry hole 
region is that of a broad, comparatively shallow trough in which occur many minor anticlines and synclines. The axis of this great trough or synclinorium passes through Knox, Whitley, and McCreary counties, east of Wayne County and a short distance west of Pine Mountain, with a trend generally northeast and southwest. The axis of the Cincinnati anticline lies west of Wayne County in Clinton and Russell counties and has a trend of about N. $20^{\circ} \mathrm{E}$. The general dip of the rocks in Wayne County is therefore toward the southeast. This dip amounts to about 20 feet to the mile between Monticello and Griffin, which is probably about the average dip of the beds across the entire county. There is, however, considerable difference in the degree and direction of dip from place to place, due partly perhaps to unconformities in the rocks of the different series and systems and to unequal deposition of sediments, but mainly to warping in the process of folding, which caused the minor folds and wrinkles that are delineated on the structure maps accompanying this report and that seem to be so intimately associated with the origin of the oil pools.

In this report on the structure of the oil sands the discussion of the dip of the beds will be confined to that of the Mississippian series, which contains most of the oil and gas pools, in order better to show the possible effect of folds on the accumulation of the oil in pools. Under the circumstances controlling the field examination time could not be given to the determination of the dip of the Mississippian rocks over the entire area, the work being necessarily confined to the areas in and immediately surrounding the more important oil fields, especially in that part of Wayne County included in the Monticello quadrangle of the United States Geological Survey.

Spirit-level lines were run to many wells in the Mount Pisgah, Parmleysville, and Griffin fielci, ;, which lie along the valley of Little South Fork River in the southern part of the county. With the time available, even the area including these fields could not be completely covered, and no attempt was made to work out the structure in the Slickford and Sunnybrook districts, in the southwestern portion of the county.

\section{METHOD OF MAPPING STRUCTURE.}

In regions where the strata are but slightly disturbed the folds can best be represented on a map by structure contour lines drawn on the top of some persistent bed that can be certainly identified over a large area, and that is hence called a key rock. Each of these contour lines is supposed to be drawn through all points on the upper surface of the key rock which are at a uniform height above some horizontal datum plane, usually sea level. In this report two key. rocks were used. The structure contour lines for the southeastern part of the Monticello quadrangle (see Pl. III) are drawn or 
the top of the Spann limestone member. Those for the map of the Cooper, Mount Pisgah, Parmleysville, and Griffin fields are drawn on the top of the Beaver Creek "sand." The datum plane for each is sea level, and the contour interval, or vertical distance between contours, is 10 feet. The contour lines are numbered to show the height in feet above sea level of the top of the key rock at the points through which the line passes on the map.

In order to draw these contour lines on Plate III, the altitude of the Spann limestone member above sea level was obtained at a great many points in the area represented by the map, and the dip of the beds was noted at other points where this limestone is not present in outcrop. These altitudes were plotted on the field map, and points of equal altitude were connected by lines conformable to the shape of the reference surface, as shown by all the other altitudes obtained. The result is a structure map which shows the altitude of the Spann limestone member or the Beaver Creek "sand" at all points in their respective areas.

\section{ACCURACY OF STRUCTURE CONTOURS.}

From the preceding paragraph it is plain that the accuracy of the structure contours depends on the number and distribution of correct altitudes on the key rock. All degrees of accuracy are therefore possible. In the present work time and funds did not permit extreme accuracy in the structural mapping. The object sought was to determine whether or not the oil pools of Wayne County have any definite relation to folds in the rocks. For this work altitudes were obtained by hand leveling from bench marks on spirit-level lines run by the United States Geological Survey. The altitudes thus obtained probably have a maximum error of less than 5 feet. The altitudes of the Beaver Creek "sand" along Little South Fork, shown on Plate VI'(p. 56), were obtained by running spirit-level lines to the mouths of many oil and gas wells and then adding the steel-line measurement made by the driller to the top of the Beaver Creek "sand." This system of levels was started from a bench mark of the United States Geological Survey on the Monticello-Parmleysville road about half a mile south of Burfield, and run to Parmleysville, thence to Mount Pisgah and Griffin. The instruments used were a telescopic alidade and plane table. The total error in this line may be as much as 10 or 15 feet, but in any field the error in the altitudes of the mouths of the wells is probably less than 2 feet.

STRUOTURE OF THE MONTICELLO DISTRICT.

MONTICELLO SYNCLINE.

The most prominent structural feature in that portion of the Monticello quadrangle shown on the structure map ( $\mathrm{Pl}$. III) is the Monticello syncline. This broad trough extends from a point on 
Beaver Creek about 3 miles below Cooper in a general easterly direction to a point on the Elk Spring Valley pike about 2 miles from Monticello; thence northeastward to a point about half a mile north of the Coffey coal bank, where the trend of the fold changes to a little south of east and leaves the quadrangle on Little Sinking Creek near the Rhoda Dodson farm. This structural trough is variable in width and depth. Along its axis the top of the Spann limestone member varies in elevation above sea level from 980 feet at the eastern edge of the quadrangle to about 1,180 feet northwest of the Coffey coal bank. For about 1 mile westward from this point the limestone dips slightly along the trough to the central part of a small oval-shaped basin and then rises about 60 feet to the Elk Spring Valley pike, where it has an altitude of about 1,225 feet. To the west the bottom of the syncline again pitches slightly to another long basin, which extends from the point where this fold crosses the Monticello-Cooper pike to a point within half a mile of Beaver Creek, where the axis of the fold again appears to rise slowly toward the west.

\section{SPANN ANTICLINE.}

Northward from the axis of the Monticello syncline and west of the Monticello-Oil Valley pike the rocks rise at a fairly uniform rate as far as structural work has been done in that direction. East of this area the rocks north of the Monticello syncline rise to the crest of a secondary fold called the Spann anticline, which has a general southeast trend from a point on the Monticello-Burnside pike about 4 miles from Monticello. The Spann limestone member is highest on this fold where it crosses the pike. It pitches about 50 feet for the first mile, then rises slightly to a small dome located on the MonticelloSpann road $2 \frac{1}{2}$ miles west of Spann. From this dome the fold makes a sharp bend to the east and continues in that direction to the edge of the quadrangle. The dip in the first half mile of this distance is negligible; in the last mile and a half it amounts to about 50 feet.

STEUBENVILLE SYNCLINE.

North of the Spann anticline the Spann limestone has a general dip east and north to the axis of the broad Steubenville syncline, which extends from the vicinity of the Sue Jones farm almost due east to the edge of the quadrangle. This small trough has a pitch to the east of about 100 feet in the first 2 miles. Beyond that point it appears to be almost level.

North of this syncline there appears to be a small secondary fold which pitches steeply from the vicinity of Steubenville in a direction a little south of east to the edge of the quadrangle. The total difference in height of the Spann limestone member between Steubenville and the eastern edge of the quadrangle along this fold is about 140 feet. North of Steubenville no attempt was made to determine the dip of the rocks. 
COOPER ANTICLINE,

South of the Monticello syncline a well-defined arch, the Cooper anticline, is shown by the contours on the structure map to cross Beaver Creek about $1 \frac{1}{2}$ miles below Cooper in a general east-west direction and extend to a point about 4 miles southeast of Monticello where the fold disappears. This anticline forms a broad, elongated dome, the center of which is about 2 miles northwest of Oil Valley. The location of the axis of this fold in the western part of the quadrangle is not known. The meager data at hand suggest that a low place on this axis occurs near the point where it crosses Beaver Creek, from which the rocks rise westward as far as they were traced. The doming of this anticline as suggested by the structure contours at the west end should not be considered as definitely established.

\section{SUMPTER SYNCLINE.}

South of the Cooper anticline the rocks dip uniformly to the axis of a broad flat syncline which extends westward from Barrier post office to a short distance west of Cooper, where it seems to disappear against the Cooper anticline. The pitch of this fold is quite pronounced at its western end, but from the vicinity of Sumpter to Barrier the axis of the trough is almost level. At Barrier this fold connects with another small trough trending about S. $15^{\circ} \mathrm{E}$., the pitch of the trough being slightly to the south. Between this part of the Sumpter syncline and the Monticello syncline to the north a broad irregular anticlinal nose juts out from the dome of the Cooper anticline in a general southeasterly direction. From the top of this fold northward along the eastern edge of the quadrangle the beds dip about 190 feet. From the same point southwestward to the axis of the Sumpter syncline at Barrier the dip is not more than 30 feet. Very little is known of the structure between the Sumpter syncline and the small area in which the structure was studied along Little South Fork from Mount Pisgah to Griffin.

\section{STRUCTURE OF THE PARMLEYSVILLE DISTRICT.}

The general attitude of the Spann limestone member was not determined in the Parmleysville district. The upper surface of the Beaver Creek "sand" was used for such structural mapping as could be done in the very short time at the writer's disposal. Contours on the top of this bed are shown on Plate VI (p. 56) in red. These contours show in part the dip of the sand in the producing portions of the Griffin and Mount Pisgah pools, and in the northern part of the Parmleysville pool. From these scanty data some general structural features can be deduced which may be of economic value to producers.

From a study of this material it seems probable that the Mount Pisgah pool is near the head of a broad shallow trough, the axis of 


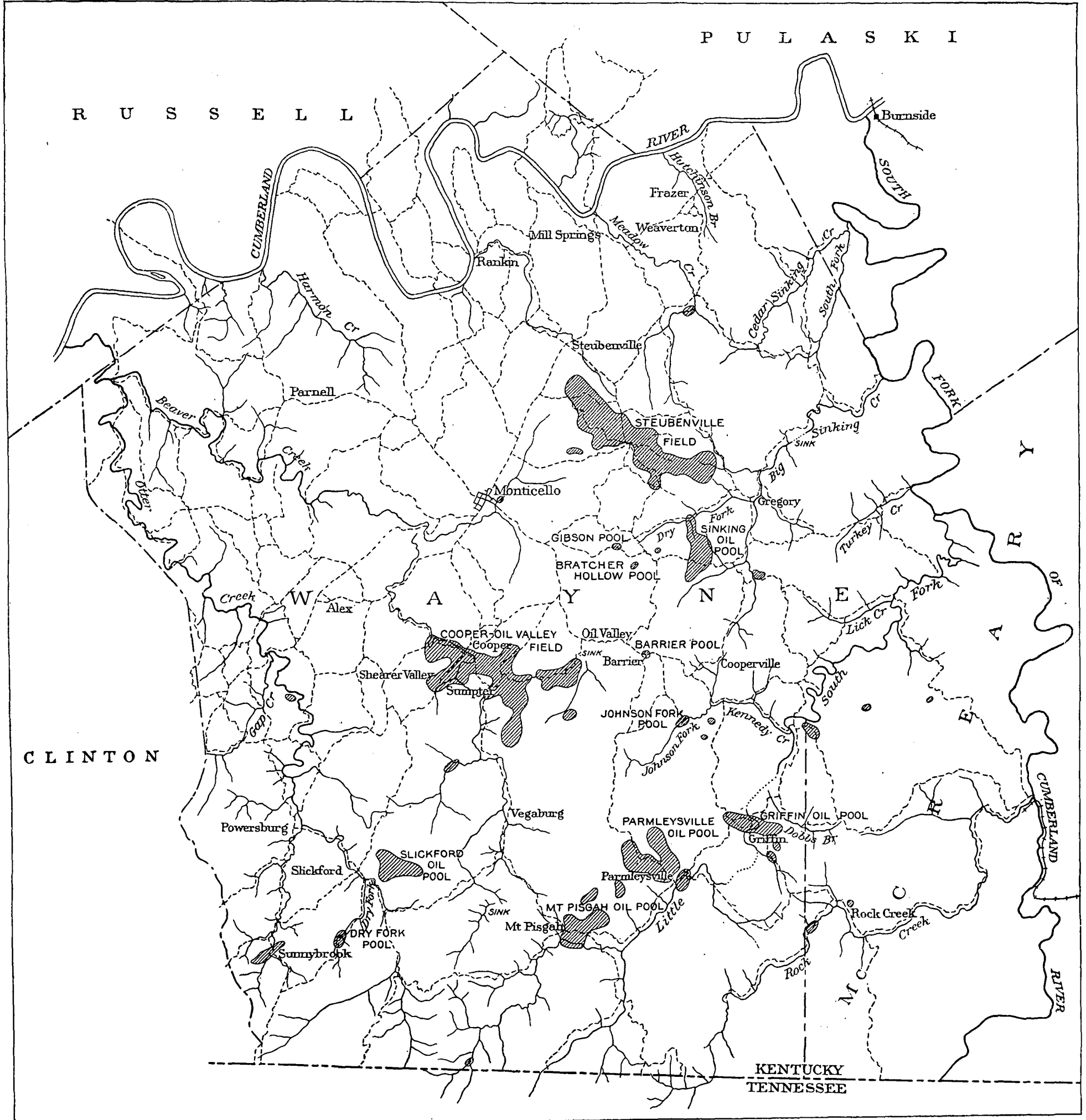


which lies probably a mile south of Parmleysville and at a somewhat greater distance south of Griffin. This trough probably deepens somewhat from Mount Pisgah to Griffin. A similar syncline appears to lie to the north of the Griffin and Parmleysville field, as is evidenced by the trend of the structure contours in these pools. The writer suspects the existence between these two synclines of a broad irregular somewhat flattened anticline, though the position of its axis in the Parmleysville pool is by no means clear. This fold very probably pitches toward the east. A more detailed analysis of the structure as shown on Plate VI (p. 56) will be made later in the discussion of these oil pools.

\section{OIL AND GAS FIELDS.}

NATURE OF EXAMINATION.

In work for this report only a few of the oil and gas fields of Wayne County were studied in detail, the object being to determine whether or not these pools show a definite relation to geologic structure, and to determine also, if possible, the value of geologic work in the location of undiscovered pools in this part of Kentucky. This work was therefore in the nature of an experiment, only such pools being selected for study as seemed to offer the best opportunities for quickly mapping the dip of the Beaver Creek "sand" and Spann limestone member. The following facts regarding these pools are not intended, therefore, to constitute a detailed report. No attempt is made to discuss the pools either in the order of their size or of their discovery. The general distribution of the oil pools of Wayne County and western McCreary County is shown on Plate IV.

\section{STEUBENVILLE OIL FIELD AND ADJACENT TERRITORY.}

- History.-The first well in the Steubenville field was drilied by the Kentucky Colonel Oil Co. on the William or Sue Jones farm, about $1 \frac{1}{2}$ miles south of Steubenville. :This well found oil in the Beaver Creek "sand" at a depth of a little over 400 feet. The date of completion of this well is not at hand, but the development of the Steubenville field, which quickly followed, appears to have been most rapid between 1904 and 1906. The field was found to be very "spotted," because of changes in porosity of the Beaver Creek "sand," considerable areas proving to be barren at places which seemed to be especially favorable on account of the general trend of the pool and the location of surrounding oil-bearing territory. The initial production of the better wells in this field ranged from 100 to probably 500 barrels a day, but most of them at their best furnished less than 100 barrels a day. The field as developed to November, 1909, extends from the Sue Jones farm south of Steubenville in a direction a little south of east for a distance of $5 \frac{1}{2}$ or 6 miles, the oil-bearing belt ranging 
from about one-half mile to $1 \frac{1}{2}$ miles in width. Very little drilling, if any, is now being done in the field. The wells decreased rapidly in daily production as soon as they were put to pumping, and many of them have been exhausted and abandoned. Those that still produce yield only a few barrols a day and their output is steadily decreasing from year to year. In 1909 the total production from this field, as reported in the Wayne County Outlook, was as follows:

Production of the Steubenville field in 1909.

\begin{tabular}{|c|c|c|c|}
\hline January....... & $\begin{array}{c}\text { Barrels. } \\
5,489\end{array}$ & August... & $\begin{array}{r}\text { Barrels. } \\
4,292\end{array}$ \\
\hline February...$\ldots \ldots \ldots$ & 4,713 & September. & 4,588 \\
\hline March........... & 4,927 & October..... & 5,784 \\
\hline April............ & 5,031 & November.: & 4,167 \\
\hline 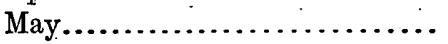 & 6,116 & December. . & 4,715 \\
\hline June.......................... & 5,144 & & \\
\hline 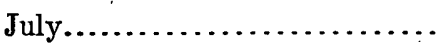 & 5,959 & & \\
\hline
\end{tabular}

This production is equal to a daily average of 167 barrels. This pool produced 757 barrels for the week ending March 9, 1912.

Oil sard.-The Beaver Creek "sand" has furnished practically all the oil found in the Steubenville field. On the Sue Jones farm this "sand" (really a limestone) varies, where productive, from 10 to 18 feet in thickness, the pay streak ranging from 2 to 10 feet below the top of the "sand." In wells Nos. 2, 3, and 13 in the middle portion of the field the Beaver Creak "sand" is 10, 20, and 14 feet thick, respectively. The average thickness of the "sand" on the Mike Boyles farm and eastward is probably between 10 and 18 feet. No measurements are at hand of the Beaver Creek "sand" in the area immediately surrounding the oil-producing portion, but it is reported to have been thin or absent in a number of places. - Little was noted regarding the average thickness of the pay streak, but it probably does not exceed 6 or 8 feet. The depth of wells to the top of the Beaver Creek "sand" in the Steubenvillo field ranges from about 400 to 700 feet, depending largely on the altitude of the surface. The Chattanooga ("Black") shale is mentioned in but few well records. In the Sue Jones well No. 58 it lies immediately below the Beaver Creek "sand" and was penetrated 20 feet. It is 30 feet thick in the Boston \& Jones heirs well No. 10 and in well No. 8 on that farm it lies 9 feet below the Beaver Creek "sand." In the H. McBeath well it is 50 feet below the Beaver Creek "sand" and is 35 feet thick.

Structure.-From the general structure contour lines on the map (Pl. III) it appears that the Spann limestone member on which they are drawn has a dip toward the east of about 40 feet across the productive belt, but this is not certain. It is important to note that the productive part of the Beaver Creek "sand" on the samo farm is at a height of 548 to about 569 feet above sea level. Eastward the pro- 
ductive belt roughly parallels the trend of the structure contours on the Spann limestone member to the edge of the quadrangle, at which point the pool appears to occupy the axis of the Spann anticline. Beyond the eastern boundary of the area shown on Plate III (p. 34) the Spann limestone member has not been traced, and the structural position of the pool has therefore not been determined.

At Spann post office the Jack Hughes wells Nos. 1 and 2 show the Beaver Creek "sand" at a height of 506 and 523 feet, respectively. On the Boston \& Jones heirs farm wells Nos. 1, 2, 4, 6, and 8 show the oil sand at 526,527,520, 538, and 518 feet, respectively, above sea level. East of Spann, near the edge of the quadrangle, the John Boston wells Nos. 2 and 13 reach the "sand" at 502, 475, and 484 feet above sea level. Between the Michael Boyles wells Nos. 8 and 17 the Beaver Creek "sand" dips from an altitude of 436 feet to 419 feet. Half a mile from the eastern end of the field the T. C. Morrow woll No. 8 found the Beaver Creek "sand" at an altitude of 376 feet. In well No. 6 of this farm it is 305 feet, and in well No. 5 it is 299 feet above sea levei. Well No. 5 is on the extreme eastern end of the Steubenville oil fieid. Less than 1 mile to the south a well drilled on the Elizabeth Dodson farm found 10 feet of hard close Beaver Creek "sand," without oil or gas, at an altitude of 389 feet. The above altitudes on the Beaver Creek "sand" show that the oil pool in it west of Spann lies along the north slope of the Spann anticline, the upper edge of the oil-bearing belt in the "sand" being almost on a level. East of Spann the upper edge of the productive part of the "sand" dips irregularly about 200 feet in about $2 \frac{1}{2}$ miles. In this part of the field the available data are too meager to more than 'merely suggest that the oil-bearing belt appears to lie on or near the north side of the pitching axis of the Spann anticline. It seems certain that the productive area on and adjacent to the James Alexander and O. Smith farms south of Spann is south of the axis of the Spann anticline. More detailed study may show a close structural connection between this part of the field and othat to the east, but this is not evident from the material in hand.

Water.-So far as the evidence goes, the Beaver Creek "sand" has furnished little' or no water in and adjacent to the Steubenville pool. Records of wells drilled below this "sand" are few, but such as are available report no water, except in the McBeath well (a log and section of which has been given under the heading "Stratigraphy"), where slightly saline water in considerable quantity was found in the St. Peter (?) sandstone at 1,660 feet below the Beaver Creek "sand."

At an interval of about 270 to 320 feet above the Beaver Creek "sand" on the Steubenville field and adjacent territory is a very persistent water-bearing bed or zone which supplies Blue Lick or sulphur water under considerable head. This water is believed to come 
from a limestone bed at or near the top of the "Waverly" formation. In the T. C. Morrow well No. 5, at the extreme eastern end of the field, salt water is reported at 110 feet above the Beaver Creek. "sand." This is the only salt water reported in the available records of this field. It appears to come from one of the thin limestone beds within the "Waverly" formation. This horizon may furnish salt water in other wells of which the writer has no record.

Gas.-Gas in considerable quantity was found in many oil wells in the Steubenville pool, and several wells on the south and west edges of the pool have supplied gas alone. Probably the best wells were on the John Bohon farm, half a mile south of Steubenville, some of which are reported to have had initial daily capacities between $1,000,000$ and 3,000,000 cubic feet. This gas is now being utilized for power by the Cumberland Pipe Line Co. Sufficient gas is still being procured from the oil wells to furnish most of the power for pumping the wells.

Test wells adjacent to the Steubenville field.-No attempt has been made in this report to locate all the wells that have been drilled in and adjacent to the Steubenville field, because many of them have long since been abandoned and their locations could not be readily found. The more significant test wells have been plotted on the map.

North of the Steubenville field two wells were drilled on the J. $\mathrm{H}$. Duncan farm by the New Domain Oil \& Gas Co. Well No. 1 is located one-fourth mile north of Steubenville; it reached a depth of about 879 feet below the Chattanooga shale, which is 30 feet thick.

A 15-foot "shell" was reported at the horizon of the Beaver Creek "sand" at an elevation of 563 feet above sea level. Well No. 2, located about 1 mile southeast of Steubenville, reports no Beaver Creek "sand" and 34 feet of black Chattanooga shale at an altitude of 477 feet. This well reached a depth of 1,150 feet, passing through the horizon of the Sunnybrook "sands." A well on the Eli Corrall farm, less than 1 mile east of Steubenville, is reported to have found 18 feet of Beaver Creek "sand," but a record of the well could not be found. The well mouth stands at an elevation of about 917 feet. A well drilled on the Dr. Joseph Jones farm, about $1 \frac{1}{2}$ miles northeast of Steubenville, is said to have found 18 feet of Beaver Creek "sand," but the record of the well was not obtained.

At the time of the writer's visit in July, 1910, two wells had already been drilled along Meadow Creek, near the eastern edge of the Monticello quadrangle. The locations of these wells are shown near the upper right-hand corner of the map (Pl: III, p. 34). Just outside the quadrangle, on Meadow Creek, eight or more wells have been drilled on or adjacent to the George Duncan farm. In two or more of these some oil was found. Another is said to be a moderately productive gas well. 
West of the Steubenville oil field, in the area shown on the map (Pl. III), a number of test wells have been drilled of which no records are at hand. These include one well on the farm of J. H. Duncan, one on that of Charles Bock, two on that of Amaziah Kelley, and the deep well on that of $\mathrm{H}$. McBeath, already discussed. A well on the Michael Castillo farm found the top of 16 feet of Beaver Creek "sand" at 381 feet and the top of the Chattanooga shale at 422 feet, the height of the Beaver Creek "sand" above sea level being 596 feet. This was a small gas well and was without indications of salt water in the Beaver Creek "sand." Wells Nos. 1 and 2 on the J. H. Gregory farm found the Beaver Creek "sand" 12 and 15 feet thick at altitudes above sea level of 598 and 591 feet, respectively. Both of these wells produced a little gas and No. 1 a showing of oil from the Beaver Creek "sand," which contained no salt water. The top of the Chattanooga shale in well No. 2 is 26 feet below the bottom of the Beaver Creek "sand."

South of the Steubenville field several unproductive wells have been drilled along the valley of Elk Spring Creek, among them being the T. J. Frogge well No. 1, the Brent Crawford well No. 1, and the R. Kendrick well No. 1 .

Two "freak" gas wells were drilled in the eastern edge of Monticello during 1908. The first well found gas in limestone at 233 feet and on down to 273 feet, the strongest flow coming from the depth of 253 feet. The top of the limestone is 176 feet above the Chattanooga shale. The well was completed to a depth of 273 feet on June 2, 1908, and shut in until August 31, 1908, when it was opened to drill deeper. On September 4 it was gaged and is said to have shown a closed pressure of 340 pounds to the square inch and a volume of about 900,000 cubic feet a day. In this well black sulphur water was found at a depth of 57 feet, gas at 92 feet, and gas and salt water at 155 feet. Later the well was drilled to the Chattanooga shale, at a depth of 400 feet, finding at 387 feet 1 foot of Beaver Creek "sand," which has an altitude of 529 feet above sea level. No water is reported below the gas-bearing strata. In the second well gas was struck at about the same depth as in No. 1. This well is reported to have had an initial production of $8,500,000$ cubic feet a day, with a closed pressure of 525 pounds to the square inch. The town of Monticello was piped to utilize this gas, but when it was turned into the lines the pressure and volume decreased rapidly, and the wells became practically exhausted within a few weeks.

South of the Steubenville field comparatively few test wells have been drilled for the first few miles. Two wells on the Isaac Draughon and Nancy Alexander farms are located near the axis of the Monticello syncline, about $1 \frac{1}{2}$ miles from the eastern edge of the quadrangle. At a depth of 516 feet the Draughon well reached the 
Chattanooga shale, which was found to be 31 feet thick. The Beaver Creek sand is absent in both of these wells. About a mile southeast of the Draughon well four more wells have been drilled on the A. R. Humble farm, near the head of Dry Fork of Sinking Creek. Humble well No. 1, drilled by E. T. Coffey \& Co., is reported to have unexpectedly flowed 25 or 30 barrels of oil from shale at a depth of 302 feet while the well was being drilled. Humble well No. 1, drilled by the Union Oil \& Development Co., found 14 feet of Beaver Creek sand at a depth of 605 feet. This sand here has an altitude of 387 feet above the sea and is 8 feet above the Chattanooga shale. Two wells were producing a small amount of oil from this farm at the time of the writer's visit in July, 1911.

On another branch of Little Sinking Creek, about three-fourths of a mile south of the Humble wells, five or more wells have been drilled on the Foster or Moore property, one of which was a small oil well and another appears to be a moderately productive gas well. The others are reported as being unproductive. The mouth of the oil well is about 1,162 feet and that of the gas well 1,193 feet above sea level. No records of the wells were obtained.

The locations of all the test wells east and southeast of the Steubenville oil field are not known. One well, drilled by Clay B. Steel on the Isaac Baker farm, is reported to have flowed 1,000,000 cubic feet of gas from the "Stray sand" at a depth of 385 feet. The closed gas pressure and the length of time this well produced are not known. Other wells on the R. B. Walker and Rhoda Dodson farms are reported to have been unproductive.

\section{SINKING OIL FIELD.}

The Sinking oil field is situated about 2 -miles south of the eastern end of the Steubenville field and less than a mile beyond the eastern edge of the Monticello quadrangle. It is about $2 \frac{1}{4}$ miles long by one-half to three-fourths of a mile in width. The sketch map (fig. 5) shows only some of the productive. wells in it.

The Sinking field was discovered in 1905 and was not fully developed in 1909. Most of the wells were small, their initial production being. below 25 barrels. The best well in the pool was Chrisman No. 7, which produced 435 barrels the first day and at the end of four months was making 200 barrels a day. The other wells rarely exceeded 200 barrels a day and decreased rapidly. The best closed. pressures in the gas wells were from about 180 to 200 pounds to the square inch. The Cyrus Brown well No. 5, drilled by the New Domain Oil \& Gas Co. and finished October 6, 1906, had a closed pressure of 105 pounds and an initial capacity of $1,344,000$ cubic feet a day. The gas came from both the "Stray" and Beaver Creek 
"sands." This well produced for about three years. An the oil in this field comes from the Beaver Creek "sand."

Salt water is reported in considerable quantities in the "Stray sand" over parts of this field. A few wells toward the southern

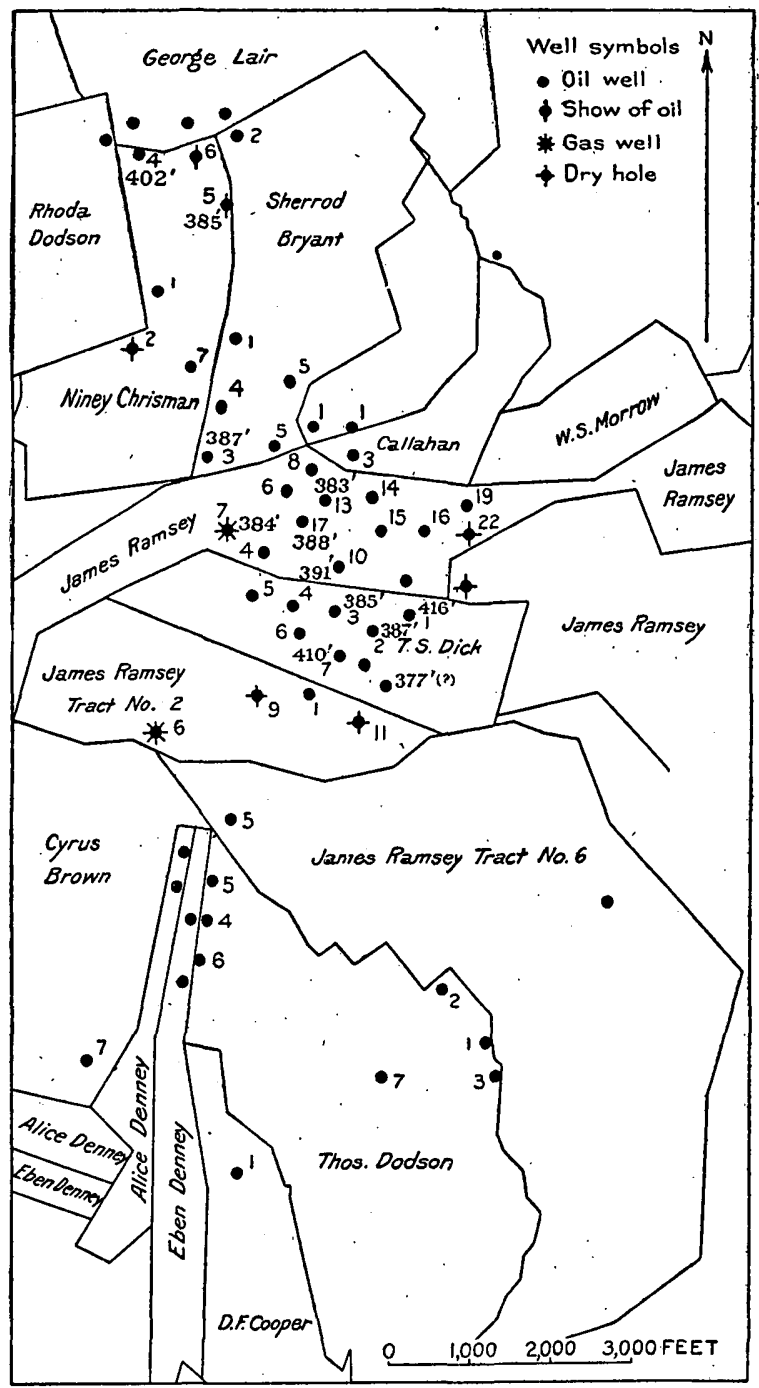

Figure 5.-Sketch map of the Sinking oil field, Wayne County, Ky., from data furnished by the Wood Oil Co. Scale 1 inch $=2,000$ feet. Numbers of wells correspond to those given in tables showing well records, pages 64-101. Figures followed by prime mark (') show elevation of well mouth above the Beaver Creek "sand."

end of the field on the T. S. Dick farm report some salt water in the Beaver Creek "sand," but its approximate volume and head are not given in the brief records.

Very little geologic data of importance are available relative to this field. A single line of spirit levels was run from the northern 
end of the Nancy Chrisman farm to the southern part of the T. S. Dick farm and the elevation of a few wells obtained. The numbers ranging from 377 to 416 on the map show the altitude of the Beaver Creek "sand" in the adjacent wells. From these few altitudes contour lines on the oil "sand" can not be drawn with accuracy. It should be noted, however; that the altitude of these wells is practically the same as those in the eastern part of the Steubenville field.

\section{BRATCHER HOLLOW OIL POOL.}

About 2 miles. west of the Sinking oil field several wells have been drilled on the Coffey and Oats property in Bratcher Hollow. The best of these wells is reported to have furnished a few barrels of oil a day when first drilled, but the total production from them has been very small. In well No. 10 on this property gas is reported to have been found in a stray "sand" about 46 feet above the Beaver Creek "sand" and at a depth of 606 feet. Some oil was found in a 10-foot pay streak of the Beaver Creek "sand." No altitudes above sea level of wells in this field were obtained and very little information is available regarding them

\section{GIBSON OIL POOL.}

Six or more wells have been drilled on the Travis Gibson farm, about $4 \frac{1}{2}$ miles southeast of Monticello. Some of these wells found considerable gas in the "stray sand," which is about 213 feet above the Beaver Creek "sand." In the Gibson well No. 1, drilled by Backer \& Co., the Beaver Creek "sand" is reported to have furnished some gas with a closed pressure of 110 pounds to the square inch. In wells Nos. 2 and 3, drilled by Wm. Gearing.\& Co., some oil and salt water are said to have been found in the Beaver Creek "sand." No salt water is reported from this "sand" in the other wèlls. Gibson well No. 5, drilled by Gearing, found the top of the Beaver Creek "sand" at a depth of 544 feet, where it is 466 feet above sea level. This well is said to have produced as much as 8 barrels a day and slowly settled to a steady production of 5 barrels a day. No good records of these wells were obtained.

Between the Gibson pool and Monticello four or more wells have been drilled in Elk Spring Valley, on the Oats and Coffey farms, all of which were unproductive. In one of these, drilled by the Wood Oil Co. on the John F. Oats farm, located about 2 miles from Monticello, 6 feet of Beaver Creek "sand" was encountered at a depth of 415 feet, where it has an altitude of 51.4 feet. The Chattanooga shale in this well is 9 feet below the Beaver Creek "sand" and is 40 feet thick. This well reached a depth of 1,254 feet and is reported to have passed through the "Pencil cave" (see fig. 2, p. 16) at 1,200 feet. No water was found below 155 feet in this well. 


\section{BARRIER OIL FIELD.}

At Barrier post office less than a dozen wells have been drilled for oil on the E. Miller and Henry Thompson farms, and possibly on adjacent property. In a few of these wells oil was found in small quantities in the Beaver Creek "sand," sufficient to justify pumping them for a short time. In 1909 all these wells had been abandoned. Level lines were run to the mouth of the E. Williams wells No. 2 and No. 9, and to the Henry Thompson well No. 1, their altitudes being 930, 924, and 1,078 feet, respectively. The record of the Henry Thompson well shows the Beaver Creek "sand" to be 463 feet above sea level at this point. It is 12 feet thick, and lies 23 feet above the Chattanooga shale. Some gas was found here in a limestone 240 feet above the Beaver Creek "sand" and salt water at 205 feet above it. This well was unproductive.

On the map a few unproductive wells are shown to have been drilled in the southeastern part of the Monticello quadrangle, surrounding the Barrier pool and southeast of Oil Valley.

\section{COOPER-OIL VALLEY OIL FLELD AND THE WESTERN PART OF WAYNE COUNTY.}

Location.-The term "Cooper-Oil Valley field" in this report is meant to include all the oil-producing areas in and south of the Monticello quadrangle from $1 \frac{1}{4}$ miles west of Cooper to Oil Valley, a distance of about $4 \frac{1}{2}$ miles. The geologic work done in this field was fragmentary and insufficient for drawing accurate structure contours on the Beaver Creek "sand." The same is true of the contours on the Spann limestone, member. It seems very probable that the contours on the Spann limestone member may prove to be quite inaccurate over the area southwest and west of Sumpter and Cooper where no elevations were obtained upon it.

History.-One of the first wells drilled for oil in Wayne County was put down in 1895 at the forks of Beaver Creek, about 2 miles south of Sumpter post office. This well furnished about 15 barrels. a day from a porous limestone, named by the drillers the Beaver Creek sand, at a depth of about 480 feet. Salt water is said to have been found in limestone 95 feet from the surface, and, at about 180 feet a considerable amount of Blue Lick or sulphur water. The well showed little loss in daily production for 10 or 12 years and is said to have been drowned out by an invasion of water, presumably from the overlying water-bearing bed. The next well drilled in this vicinity was on the Miller farm, but no facts are at hand regarding i.t. The third well was drilled on the Sandusky property, near Sumpter, in 1896 or 1897. It began flowing at the rate of about 100 barrels a day, and is said to have maintained this rate for 19 days. This strike led the Cumberland Pipe Line Co. to lay a pipe $29755^{\circ}-$ Bull. $579-14-4$ 
line to the well from Somerset. . With a market for the oil, drilling was rapid, a large portion of the Cooper-Oil Valley district being developed within the three years following.

Structure.-The general structure of the Spann limestone member in the Cooper-Oil Valley field is shown by red contour lines on the map (PI. III, p. 34) to be that of a broad, flat trough, called the Sumpter syncline, trending almost east and west, roughly parallel to the longer axis of the oil-producing belt. Near the eastern end of the field the oil is found at or near the axis of the syncline. Westward from the middle of the field the productive area rises higher and higher along this trough, northwest of Cooper, to a point where it appears to reach well up toward the axis of the Cooper anticline on the William Hurt, T.S. Oats, and R. E. Vickery farms. The greatest difference in altitude of the Spann limestone member within the field is about 100 feet. The variation in altitude of the Beaver Creek "sand" within the oil-bearing portion of this field is not known, but it is probably over 100 feet. At the extreme eastern end of the field, on the A. J. Roberts property, the Beaver Creek "sand" has an elevation between 430 and 440 feet above sea level. On the. B. E. Roberts farm, farther west, the altitude of this sand ranges from about 430 to 470 feet, the highest being in wells farthest west. On the Coffey farm, along the dividing ridge between Elk Spring Valley and Beaver Creek, the oil sand has an altitude of about 485 to 495 feet. Farther south along this ridge, on the Miller property, in what is locally called the Stillhouse Hollow pool, the oil "sand" lies at a height of 500 to 516 feet in the wells to which levels were run and of which records were obtained.

Spirit levels were run to a number of wells on the B. S. Huffaker farm, north of Sumpter post office, and the records procured. From these data it appears that the structure of the Beaver Creek "sand" in this part of the Cooper-Oil Valley field is that shown on the accompanying map (fig. 6 ).

From the map (fig. 6) it is seen that the exact position of the axis of the Sumpter syncline is not known, though it appears to lie north of the Huffaker farm. The position of this fold in the Spann limestone member has not been definitely determined over a considerable area around Cooper and Sumpter. It will require much more time than could be allotted to this, work to map in detail the structure of the rocks in this vicinity. The Beaver Creek "sand" has an altitude of 480 to 554 feet across the area nver which structure contours are drawn.

Water.-Special attention should be called to the underground water in wells on the Huffaker farm as shown in figure 6. An examination of the records of these wells as given in the table at the end of this bulletin shows that wells Nos. 5, 6, 7, 8, 9, 10, and 12, which 
found the oil "sand" at points structurally lowest, furnished no water of any kind, except Blue Lick, in beds from 200 to 300 feet above the Beaver Creek "sand." On the contrary, in some wells

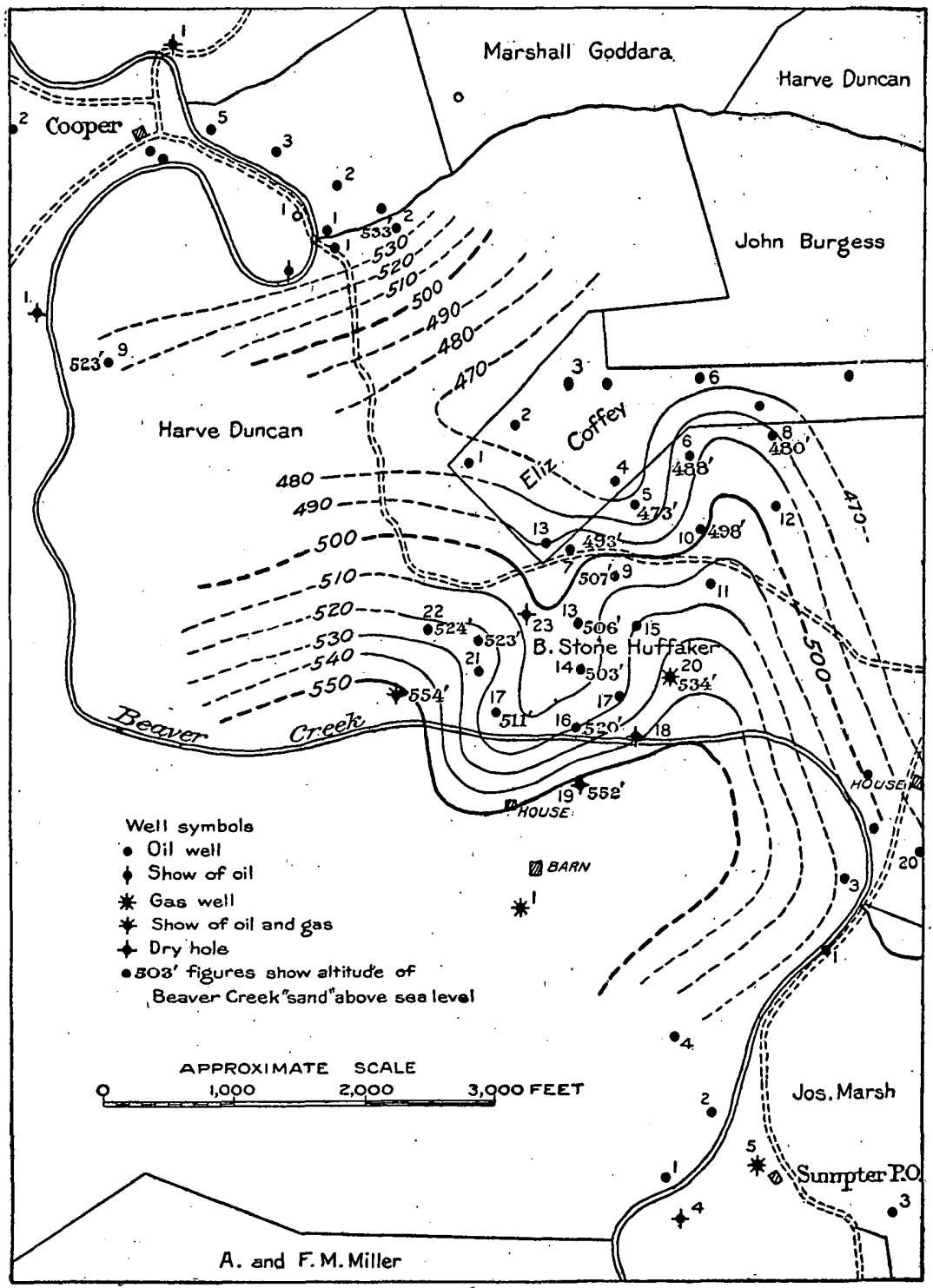

FIGURE 6.-Sketch map of that part of the Cooper-Oil Valley field situated just north of Sumpter post office, showing structure of the Beaver Creek oil "sand." Numbers of wells correspond to those given in tables showing well records, pages 64-101. Contour lines show height of Beaver Creek "sand" above sea level.

near the southern side of the field, where the sand has a higher altitude, more or less salt water was found. In this connection it should be noted that probably 200 to 350 feet above the Beaver Creek 
"sand" the "Waverly" formation contains only a few thin beds of limestone. (See fig. 4, p. 25.) In Huffaker well No. 22 salt water occurs in two places, at 128 and 30 feet, respectively, above the Beaver Creek "sand." The upper salt water entered in sufficient quantities to require casing off; the lower supply was exhausted by pumping. In well No. 24 the salt water was found at 71 feet above the Beaver Creek "sand" in such quantities as to require casing. In well No. 16 very strong salt water was encountered 180 to 170 feet above the. Beaver Creek "sand." In well No. 20 the salt water was found 99 feet above the oil "sand." This "sand" is reported absent in Huffaker well No. 18, and in No. 19 the bottom of the "sand" is 43 feet above the Chattanooga shale. Considerable salt water was found in well No. 3 at a level only 40 feet above the Beaver Creek "sand." This well was finally exhausted by pumping. The data presented show that (1) the salt water is not found in or below the Beaver Creek "sand"; (2) it is not found in wells at the lowest places structurally; (3) it occurs at very irregular heights above the oil "sand"; (4) it is seemingly most abundant where it is farthestabove the oil "sand"; and (5) where it occurs a short distance above the Beaver Creek "sand" the supply may be exhausted by pumping. These facts alone are far too incomplete and local in character to be used as a basis for theoretic conclusions, but if such material is carefully recorded by oil men in future work in this region it may eventually prove to be of special importance to geologists in settling the question of the origin and the causes of accumulation of oil and gas in this region.

Nothing was learned about the structure of the Beaver Creek "sand" in the oil field west of the area shown in figure 6. In fact, the exact outline of the area that has produced oil is not known. The altitudes of a few wells on the B. S. Huffaker farm, west of Beaver Creek, and on the William Gregory, William Duncan, and the W. E. Hurt farms were taken, but no records of them were procured. In the extreme northwest end of the field 5 wells drilled on the R. E. Vickerey farm by the New Domain Oil \& Gas Co. found the Beaver Creek "sand" at a depth of 403 to 417 feet, the average height of this "sand" above sea level being about 501 feet.

The western portion of this field is practically exhausted, and fow producing wells now remain. A knowledge of the structure of this part of the field would be of considerable theoretic interest if determined very accurately, but it was thought very doubtful if sufficient data had been preserved by the oil men to justify the time and expense of attempting such a study. The general dip of the strata indicated by the altitudes of the Spann limestone member, as shown on the map, suggests that the Sumpter syncline ends a short distance west of the oil field. The strata rise steeply westward from that point to 
the vicinity of Shearer Valley, beyond which they have not been traced.

This field shows the same "spotted" characteristics as the Steubenville and the Sinking fields. There appear to have been a number of very productive patches of the Beaver Creek "sand," separated by areas in which the wells were either small or dry. This condition is largely due to the character of the "sand" (limestone), which changes in porosity very greatly within short distances. It is probably also due in a less degree to the variation in the structure of the oil "sand."

Production.-The greatest daily production of the largest well in the Cooper-Oil Valley field is not known. Many wells exceeded 100 barrels a day, and it is believed that the best well yielded less than 500 barrels. The field has been fully developed for 10 or 12 years, and has shown more than ordinary lasting qualities in comparison with other oil-bearing areas in the Beaver Creek "sand." The pipeline reports show that this pool produced about 1,100 barrels a week in 1909. In March, 1912, it probably did not exceed 100 barrels a day, many of the wells having been exhausted and abandoned within the previous two years.

Test wells in the western part of Wayne County.-At the time of the development of the Cooper field a number of dry holes were drilled along. its western margin in an endeavor to find a further extension to the field. These were not noted in the field work for this report.

Near the head of Shearer Valley a well was drilled on the Andrew Young farm, where a good gas flow is reported to have come from the Beaver Creek "sand." About half a mile farther north a well drilled by the Wood Oil Co. on the J. B. Huffaker tract is also reported to have furnished some gas. In the same valley, about $1 \frac{1}{2}$ miles southwest of Bethesda, a well on the R. B. Hubbard farm is reported to have reached the Beaver Creek "sand" at a depth of 475 feet, which, if the report is true, found this "sand" at an altitude of about 590 feet. The well supplied some gas from the "Stray sand" at a depth of about 300 feet. A small gas well was also drilled on the W. IK. Gillespie farm, about one-half mile south of Bethesda. This well lies at an altitude between 930 and 945 feet above sea level. Another test well was drilled on the E. H. Wray farm, about threefourths mile northwest of Bethesda. The mouth of this well is about 1,010 feet above sea level. At Flat Rock Springs a dry hole was drilled on the Levi Ferrel farm, just across Beaver Creek from the springs. About half a mile farther downstream sulphur water flows copiously from another "dry" hole on the M. F. Sexton farm. The deep well drilled to a depth of 2,003 feet at Murl post office found the Beaver Creek "sand" at an estimated height between 570 and 590 feet above sea level. A record of this well is given on page 13 and in figure 2 (p. 16). 
A number of wells were drilled several years ago on Otter Creek about $1 \frac{1}{2}$ miles southeast of Zola. In one or two of these wells, on the T. B. Kennedy farm, small quantities of oil were found in the Beaver Creek "sand." One well was drilled on the Frank Upchurch farm and one or more on the R. N. Hicks farm by Ross, Wetzel \& Co. The Upchurch well is said to have furnished a small quantity of oil from the Beaver Creek "sand." Hicks well No. 1 is reported to yield a small quantity of oil with flowing salt water, presumably from the "Stray sand." None of these wells have produced in commercial quantities, and at the time of the writer's visit no development work was being done in this vicinity. It is probable that other wells have been drilled still farther down Otter Creek and in the extreme northwestern portion of Wayne County on Cumberland River and near the mouth of Beaver Creek. This part of the county was not visited by the writer.

\section{NORTHERN AND EASTERN PARTS OF WAYNE COUNTY.}

Parnell pool.-A well was drilled in 1900 by P. M. Berwald on the Polly Lair. farm, about 1 mile from Parnell. This well supplied about 7 barrels of oil a day from two pay streaks at depths of 595 and 692 feet, which are, respectively, 391 and 478 feet below the Chattanooga shale. This oil has a light-green color, contains much gas, and is highly charged with hydrogen sulphide. The greatest daily capacity, noted above, has been maintained with but little loss for the last nine years. Other wells were drilled within 300 feet of Lair well No. 1 on all sides without finding either oil or gas.

Scattered wells.-About a mile north of Parnell a well drilled on the Butler farm by Vogler Bros., found the Chattanooga shale at a depth of 212 feet. This well reached a total depth of 2,050 feet and stopped in hard white sand, probably the St. Peter sandstone, which contained considerable quantities of Blue Lick water. In 1904 or 1905 two wells were drilled in the valley of Cumberland River, a short distance north of Mill Springs, on the Shelby Brown and McBeath farms. In the Brown well the Beaver Creek "sand" was found at a depth of about 96 feet and the Chattanooga shale 40 feet below it. Some salt water was found in this well at a depth of 60 to 80 feet. The McBeath well reached a depth of about 900 feet, the Beaver Creek "sand" being found at 160 feet. A slight show of gas was found in this well but no salt water. Other wells have been drilled in the vicinity of Mill Springs and Frazier and farther to the west along Cumberland River, all of which were unproductive. On the Riley Correll farm near Correll post office, an unproductive well, drilled by the New Domain Oil \& Gas Co., found the Beaver Creek "sand" at a depth of 413 feet, the "sand" being 25 feet thick and of good quality. The Chattanooga shale in this well was 48 feet thick, the top being 20 
feet below the "sand." At Pueblo a dry well was drilled by the New Domain Oil \& Gas Co. to a depth of about 1,500 feet, on the Greenville Dick farm. A well drilled by this company on the Eli Walker farm, about $1 \frac{1}{2}$ miles southwest of Denny, was also drilled to a depth of about 1,500 feet and found a show of oil in the Beaver Creek "sand." Another dry hole was drilled on this farm by the New Domain Oil \& Gas Co., about 1,200 feet north of the first. Four wells have since been drilled on this farm by Porter Bros., in one of which about 1 barrel of oil a day was found in the Beaver Creek "sand." The other wells were said to have been dry. In this part of the county a small pool was developed on the Brown \& Nixon farm by about six wells, drilled by the New Domain Oil \& Gas Co. The first well reached a depth of 1,500 feet and was dry. The second had an initial daily production of 200 to 400 barrels. Two other wells near this one produced from 5 to 10 barrels a day and two others were small gas wells. The production of this pool ran down rapidly and the field was exhausted in less than two years. All the oil came from the Beaver Creek "sand."

On Fannys Creek a small pool has been developed by a number of wells on and adjacent to the J. T. Tompkins farm. No information in regard to this pool is available.

\section{SCATTERED WELLS AND SMALL POOLS IN THE SOUTHERN PART OF WAYNE COUNTY.}

The general position of test wells and the producing areas in the southern part of Wayne County is shown on Plate V.

CORDER POOL.

In the southeastern portion of Wayne County, or just across the line in McCreary County, on Middle South Fork River, oil was found a number of years ago on the James Corder property. This pool is said to have furnished a well with a capacity of more than 2,000 barrels a day from the "Stray sand," about 200 feet above the Beaver Creek "sand" and at a depth of less than 300 feet. This oil is reported to have come entirely from crevices in a gray limestone. The wells were very short lived, the oil giving way to water. This field was not visited by the writer and no detailed information is available regarding it.

\section{JOHNSON FORK POOL.}

In 1908 a small oil pool was developed on Johnson Fork, about 4 miles north of Parmleysville, by the Demsey Oil Co. In November, 1.909, this pool consisted of 17 producing wells on the Aaron Barrier and Miles Gregory farms. These wells found oil in the "Stray sand" at a depth of 200 to 250 feet. This oil is said to come entirely from 
crevices in a grayish limestone within a zone of about 50 feet. The wells had an initial production from a few barrels up to as much as 200 barrels a day, the average being over 50 barrels. Two or more gas wells have been drilled on the western side of this pool, on the Preston Miller farm, which have furnished closed pressures of 40 to 50 pounds, and initial capacities up to probably more than $1,000,000$ feet a day for a short period. This pool is located at a point where the height of the Beaver Creek "sand" is from 400 to about 420 feet above sea level.

In the Johnson Fork pool salt water has been reported in three wells, into one of which it entered in sufficient quantities to shut off the flow of oil. No water was reported from the Beaver Creek "sand" in this.field. All of the four wells drilled to the Beaver Creek "sand" in this pool were unproductive. The "sand" is reported to range from 5 to less than 10 feet in thickness and as a rule to be hard and close.

ROCKY BRANCH POOL.

During the fall of 1909 four wells were drilled on Rocky Branch, about $1 \frac{1}{2}$ miles southeast of the Johnson Fork pool. In well No. 2 on the Grant Roberts farm, at a depth of 187 feet, oil was found which rose to a height of 125 feet above the "Stray sand." In wells Nos. 1 and 2 on the R. G. Bell farm the Beaver Creek "sand" was reached at depths of 501 and 598 feet, respectively, the "sand" being 15 feet thick in well No. 1 and 12 feet thick in well No. 2 . In well No. 2 oil was found in the "Stray sand" at a depth of 380 feet. Along Rock Creek, in the southeastern part of Wayne County, and the southwestern part of McCreary County, a number of wells have been drilled, in some of which small quantities of oil were found in the Beaver Creek "sand," but no pools of commercial size have yet been developed. Also a small pool of oil has been developed by probably half a dozen wells on South Fork River, on the Cockrill \& Keeney property, but, no information in regard to this territory has been collected.

\section{SUNNYBROOK POOL.}

A well was drilled in 1901 on the J. S. Bertram farm, near Sunnybrook, in the extreme southwestern portion of Wayne County. "This well found oil in what came to be known as the Sunnybrook "sand" and began producing at the rate of about 200 barrels a day. "Between 1901 and 1903 this pool was fully developed; its length was about $1 \frac{1}{2}$ miles and its average width about 1,000 feet. Most of the oil was found at a depth of about 550 feet below the Chattanooga shale. It is said to have come mainly from crevices in the porous limestone, which is of Ordovician age. The productive area was on the farms of J. S. Bertram, J. C. Bertram, R. S. Bertram, C. T. Dalton, Geary \& 
Waddell, Lizzie Lester, and B. E. Peercy. Many of the wells produced as much as 100 barrels a day, but few of them exceeded 200 barrels a day. The pool was very short lived. Within a few months after the first well was drilled water appeared in this well and slowly encroached on the oil-producing territory until the entire area was flooded and the wells produced water exclusively. Wells threatened by the encroachment of this water doubled their capacities for a short time preceding the appearance of water in them, after which the change was very rapid from oil to water. The J. S. Bertram well No. 11 was pumping 75 to 80 barrels a day and increased to 150 barrels within one week, but then within 24 hours changed entirely to water. In 1909 this pool had been entirely exhausted and the wells abandoned.

\section{DRY FORK POOL.}

In 1902 to 1904 the Mayfield Oil Co. opened up a small oil pool on Dry Fork, about $2 \frac{1}{2}$ miles south of Slickford. This pool had a maximum production of about 275 barrels a day from about 20 wells in the Beaver Creek "sand." In 1909 it had an estimated production of about 25 barrels a day from 14 wells. No other details regarding this field were obtained.

\section{SIICKFORD OIL FIELD.}

The first well drilled in this field, and probably one of the first wells in Wayne County, was put down on the Morgan farm near Slickford. Oil from this well was hauled by wagon to Rowena on Kentucky River and shipped by boat to Nashville. No detailed records of these old wells are at hand. They are reported to have been from 200 to 400 feet in depth. It is estimated that the Beaver Creek "sand" in this vicinity is about 400 feet from the surface in the valleys, and it is possible that this old well procured oil from that stratum. On the Cyrus Brown farm a small well produced about 150 barrels of oil from this shallow "sand" at a depth of about 200 feet.

A well drilled on the Ruth Upchurch farm in 1905 by the Turkey Rock Oil \& Gas Co. began producing about 150 barrels a day from the Beaver Creek "sand." This well led to the development of what is locally called the Turkey Rock pool of the Slickford field, which covers all or a portion of the following farms: Ruth Upchurch, C. A. Williams, A. M. Williams, William Marsh, State National Bank, T. T. Davis, G. W. Morris, J. F. Young, W. A. Young, M. E. Hall, Davidson, Hicks, James Coope, and J. A. Brown. In 1909 about 150 producing wells had been drilled in this pool. At that time the total production of the field was about 200 barrels a day. Salt water was found at a number of places in the "Stray sand" in this field. Very salty water has been reported from the Beaver Creek "sand" at 
places along the northern edge of the field, where it is said to increase in amount with pumping and to seriously retard production. No spirit-level lines were run in this field, and only a portion of it is shown on the farm line map (Pl. V).

\section{YOUNG POOL.}

A small oil pool was developed a number of years ago on the left fork of Beaver Creek, about $3 \frac{1}{2}$ miles southwest of Sumpter, by about 10 or 15 wells on the W. A. Young and J. H. Edwards farms. This pool lies in the "Stray sand" at a depth of about 150 feet. The largest wells produce about 200 barrels a day but were pumped out within one or two months. No water is said to have been found with the oil in this.pool.

\section{PARMLEYSVILLE DISTRICT.}

In this report the Parmleysville district includes the Mount Pisgah, Parmleysville, and Griffin oil fields, as shown on Plate VI. Spiritlevel lines were run to many of the wells in this district, and the dip of the Beaver Creek "sand" was ascertained in more or less detail over a considerable part of the producing areas. The object of this work was to determine the approximate structural relationship of these three fields, so that their structure might be compared with that of the Steubenville and the Cooper-Oil Valley fields. The work was reconnaissance in nature, and therefore the structure which is shown by the red contours on Plate VI may be more or less in error, especially where the contours are dotted.

\section{MOUNT PISGAH FIELD.}

History.-Gas was found several years ago in considerable quantities in the "Stray sand" in four or five wells drilled on the K. T. Turner farm, about $1 \frac{1}{2}$ miles east of Mount Pisgah. Some of these wells are reported to have had an initial daily capacity of more than $1,000,000$ cubic feet. One or two of them found good shows of oil in the "Stray sand." The gas wells were short lived and have long been abandoned.

A number of other wells were drilled northwest of Mount Pisgah on what is now the Alfred Cooper farm, in two or three of which a small production of oil was obtained from the Beaver Creek "sand." Gas wells were also found in this "sand" on the Keeton farm, west of Mount Pisgah. In 1908 the Wood Oil Co. drilled a well on the H. T. Hurt farm, which began flowing at a rate of several hundred barrels a day from the Beaver Creek "sand." Other wells on this farm and on the S. C. Dobbs, T. B. Dobbs, and Alfred Cooper farms have developed a pool covering less than 1 square mile, which in March, 1912, was being slowly extended. Practically all the oil in this pool comes 


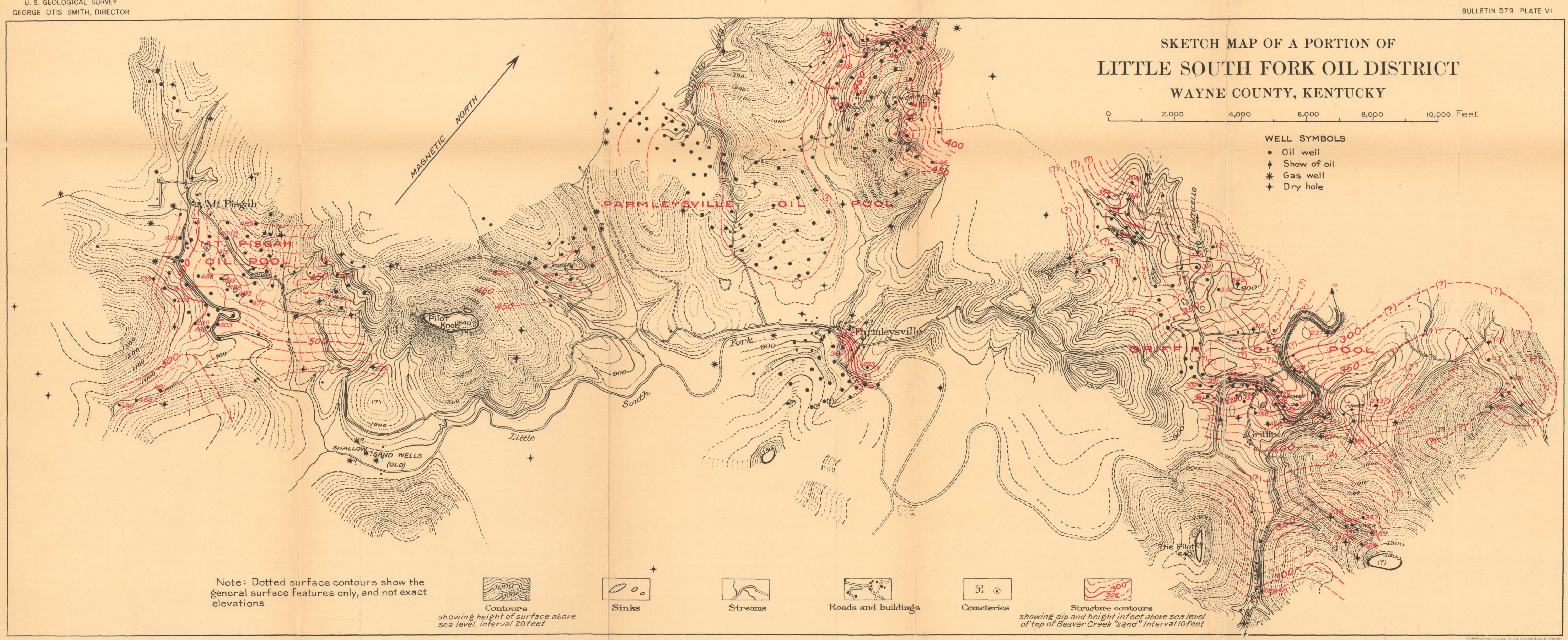


from the Beaver Creek "sand," though small quantities were found in the "Stray sand" in a few wells: In most of the wells the initial daily capacity was less than 50 barrels, but in a few of them it was as much as 150 to 200 barrels. Gas which had an initial closed pressure of about 145 pounds, was obtained in the Beaver Creek "sand" on the S. C. Dobbs farm, at the western end of the field. The capacities of these wells are not known. In this pool the Beaver Creek "sand" ranges from a thin film to probably 30 feet in thickness, and, as elsewhere in this county, it is a gray to brown calcitic cherty limestone, lying between 4 and 20 feet above the Chattanooga shale.

Structure.-The Mount Pisgah field appears to occupy the western end of a broad flat-bottomed trough which extends almost due east from the field. The structure is very similar to that of the western ends of both the Steubenville and the Cooper-Oil Valley fields described above. At the western side of the field the top of the Beaver Creek "sand" ranges from about 500 to 530 feet above sea level. It is probably as low as 440 feet above sea level at the eastern end of the field. These altitudes are almost identical with those given above for both the Steubenville and the Cooper-Oil Valley fields, showing a remarkable uniformity in the height of the Beaver Creek "sand" where it is oil producing in this county. The dip of the Beaver Creek "sand" in the Mount Pisgah field is shown by contour on Plate VI.

Water.-No salt water is found in or below the Beaver Creek "sand" in the Mount Pisgah field. It is found, however, in considerable quantities over most of the field in the "Stray sand" at'150 to 200 feet above the Beaver Creek. ' In the Alfred Cooper well No. 1, which is one of the three producing wells at the extreme south end of the field, salt water flowed from a limestone 166 feet above the Beaver Creek "sand." In the Cooper wells Nos. 3, 6, and 7, on the same farm, very salty water was found 120 to 129 feet above the Beaver Creek "sand."

\section{PARMLEYSVILLE FIELD.}

History.-Parmleysville field, as developed up to November, 1909, covers a roughly triangular area, each side of which is about $2 \frac{1}{2}$ miles in length. The oil in this field comes entirely from the Beaver Creek "sand," which lies at an altitude between 400 and 500 feet above sea level. The largest well in the field is not known. The John Keeton well No. 3, at the extreme west end, began producing about 100 barrels a day, and maintained a daily production of more than 40 barrels for the first year. Other good wells were obtained on the James Burnett farm at the northern end of the field. The initial production of most of the wells in this field ranged from 2 to 40 barrels a day. The development began in the southwestern portion of the field, where a small pool was found on the John Keeton farm, and another on the Alvis Hurt, Cullen Koger, and adjoining farms. 
At about this time another small pool was developed on the M. W. Powers property, just south of Parmleysville post office. In 1907 or 1908 the Parmleysville field was extended to the northeast by the development of a very productive pool on the James Burnett, W. M. Powers, Foster, Davis, and Faust farms.

The Beaver Creek "sand" in this region varies greatly in thickness and character. The gas pressure in it appears to have not exceeded 150 pounds to the square inch. The rate of decrease of production in the field is much less rapid than that of most of the fields of Wayne County. The field is now down to a settled production, which is slowly decreasing from year to year. Many of the wells have already been exhausted and abandoned.

Structure.-For lack of time the structure of the Parmleysville pool could not be mapped in detail. Levels were run to a few wells on the John Keeton, Alvis Hurt, and J. R. Bell farms in the southwestern part of the pool, and to most of the wells on the James Burnett farm, and to some on the M. W. Powers, F. Foster, Marcus Foster, and Davis farms in the northeastern part of the field. Records of nearly all these wells were supplied by the owners, and it is believed that the contour lines, as shown on Plate VI, depict the general structure of the Beaver Creek "sand" fairly accurately. From these contour lines it will be seen that the Beaver Creek "sand" dips steeply to the north around the northeast margin of the pool, and that the lower side of the productive area is bounded very closely. by the 400 -foot contour. The altitude suggests that the Parmleysville pool occupies a broad, flat terrace or a flat-topped anticline in the Beaver Creek "sand," where it lies at an altitude of about 400 to 475 feet above sea level.

Water.-Little water is reported in and below the Beaver Creek "sand" in the Parmleysville field. The "Stray sand" in this field, as in most other fields of Wayne County, carries water, which is reported in some wells to be salty., but no other details regarding the water in this "sand" are at hand. "The Parmleysville field is separated by about a mile of barren territory from the Mount Pisgah field on the west and by about the same distance from the Griffin field on the east. The character of the "sand" between these fields is not known, but in a few of the dry holes in these areas it is reported to be absent, and in others hard and close, without oil, gas, or water.

\section{GRIFFIN FIEIDD.}

History.-The Griffin field has been developed since the spring of 1909, at which time a few scattered wells had been drilled on the James Rice and J. W. Steel farms. In January, 1912, this field consisted of two or three more or less completely isolated areas, the territory between which had not been fully developed. One of these 
developed localities was on the William Gregory and James Gregory farms at the extreme western end of the field. This pool also included some wells on the Rice and Clark tracts. Another pool had been fairly well outlined by dry holes to the east on the J. W. Steel farm, just north of Griffin. A similar pool had also been partly developed farther to the east, on the Rock Creek Property. Co.'s farm. This pool was separated from another about $1 \frac{1}{2}$ miles northeast of Griffin on the Denny heirs' property. ' It seems probable that future development will connect some of these pools.

Gas and some oil have been found in a number of wells in the "Stray sand," but most of the oil comes from the Beaver Creek "sand," which lies at a depth of 400 to 500 feet. The best well in the field did not exceed 300 barrels a day. The average wells range from 5 to probably 30 barrels a day, though a few wells have a daily production of more than 100 barrels. The Beaver Creek "sand" ranges in thickness from a feather edge to about 30 feet, averaging between 15 and 20 feet. It shows its customary abrupt variation in porosity from well to well.

Structure.-The dip of the Beaver Creek "sand" in part of the Griffin field is shown by the red contours on Plate VI. At the time field work was done the pool had not reached a state of development that would enable a detailed structural map to be made of the Beaver Creek "sand" for all the productive territory. The contours show that the lower edge of the productive area in the Beaver Creek "sand" is closely outlined by the 320 -foot contour and that the highest point on the "sand" which has been found to contain oil is less than 400 feet above sea level. The pool appears to lie along the northern side of an anticline which crosses Little South Fork about one-fourth mile southwest of Griffin; except a small area on the Rock Creek Property Co.'s farm, about three-fourths of a mile southeast of Griffin, and the two small producing wells on the Cephas Rice farm. These areas appear to lie on the south side of this fold at about the same altitude. At the time field work was done a number of wells on the E. L. Foster and James Rice farms, which are shown on the map, had not been drilled. The dip of the Beaver Creek "sand" in this portion of the field is therefore somewhat in doubt. No records of the wells drilled by Rust \& Co. on the James Gregory farm could be secured. It seems probable, however, that in well No. 13 on this farm the Beaver Creek "sand" has an altitude of about 380 feet above sea level, and therefore is at approximately the highest point where oil has been found in the Beaver Creek "sand" in this field. The structure contours indicate that a broad syncline exists in the Beaver Creek "sand" somewhere to the northeast of the Griffin pool, but work was not extended over sufficient territory to permit the mapping of this trough. 
Water.-No salt water was found in the Beaver Creek "sand" in the Griffin field. In the J. W. Steel well No. 1 fresh water was reported at a depth of 40 feet and sulphur water with some gas at 140 feet. More gas was found at a depth of 220 to 260 feet and oil at 306 feet. In the J. W. Steel well No. 3 sulphur water was found at 145 to 148 feet. In the records at hand no salt water is reported as coming from the "Stray sand," which lies from 150 to 200 feet above the Beaver Creek "sand."

Future extensions of the Griffin field.-It seems probable that extensions to the Griffin field may be made along a belt where the Beaver Creek "sand" lies at an altitude between 320 and 380 feet above sea level. The direction of the contours, as shown on Plate VI, indicates that this belt will be found to include some undeveloped territory west of the new wells that have been drilled on the E. L. Foster and James Rice farms, west of the Griffin-Parmleysville Road. The extension of the pool in this direction appears to be made possible by the shallow trough which passes across the James Rice farm a short distance west of the crossroads 1 mile northeast of Griffin. No data are at hand, however, to show how far this trough extends to the west. It is known that the Beaver Creek "sand" rises toward the west, and it is therefore probable that the oil territory may extend to or beyond the top of the hill south of the Griffin-Parmleysville Road. This extension, of course, is dependent on the continuation of an open porous pay streak in the Beaver Creek "sand." Another possible extension to the Griffin field appears to be along a narrow belt passing east from the bend in Little South Fork, about half a mile northeast of Griffin. Wells located in this belt above the 320-foot contour, as shown on Plate VI, should have a good chance of getting oil if the Beaver Creek "sand" is of fair quality. In fact, there is no structural reason why the productive territory. may not extend in this direction to the small pool on the Denny heirs' property. Two wells on the Cephas Rice farm, south of Griffin, and the five producing wells on the Rock Creek Property Co. farm, southeast of Griffin, suggest strongly that a pool may be developed along the southern side of the anticline between these developments. The three dry holes on the J.W. Steel property between these developments may indicate a poor quality of sand in this area. As a purely wildcat undertaking, the territory in the vicinity of the Pilot Rock, south of Griffin, and as far west as Little South Fork, may prove worthy of a test. In the northwestern part of the Griffin field it seems probable that a further extension of the field may be made by wells drilled a little west or north from the William Gregory well No. 1 of Rust \& Co. All these suggestions are based on structural conditions alone and do not take into account the quality of the Beaver Creek "sand." 


\section{GENERAI, CONCLUSIONS.}

As shown by the foregoing data the productive areas in the Beaver Creek "sand," so far as they have been examined in Wayne County, show a structural relationship, which may be briefly summarized as follows: The height of the producing area in the Beaver Creek "sand" in the Steubenville field ranges from a maximum of about 560 feet at the western end of the field to about 300 feet at the eastern end, the pool being situated on the north slope of the Spann anticline and, at the western end, at the head of a canoe-shaped syncline which pitches toward the east.

In the western end of the Cooper-Oil Valley field the maximum altitude of the Beaver Creek "sand" in the producing area is between 520 and 570 feet, where the field occupies the western end of the Sumpter syncline, the productive part of the sand in this syncline dipping to the east with an altitude of about 430 feet at Oil Valley.

In the Parmleys ville district the highest portion of the Beaver Creek "sand" is in the western portion of the Mount Pisgah pool, where it is about 520 feet above sea level. Eastward from this point the productive area in this "sand" decreases in altitude to about 400 feet at the northeastern edge of the Parmleysville pool, and in the Griffin field the altitude of the oil-bearing portion of the Beaver Creek "sand" reaches a minimum of about 320 feet. The geologic similarities of these three districts are (1) the clearly marked tendency of the oil to occupy the sides and bottoms of structural troughs; (2) the definite decrease in altitude of the sand in the productive areas from west to east in each district; and (3) the approximately uniform altitude of pools in the Beaver Creek "sand:"

This tendency of the various fields toward a definite structural grouping seems more remarkable when the variability in porosity and the irregularity in distribution of the Beaver Creek "sand" is considered. The possibility of this tendency being due in part to the wider distribution of this limestone in structure troughs than on the adjacent anticlines, because of conditions of deposition or because it may mark the horizon of an unconformity, can not, for want of data, be discussed in this paper. That this relation does exist between the structure of the Beaver Creek "sand" and its oil-bearing areas is the fact of special importance to oil men. The fragmental and disconnected data presented above probably justify the assertion that good detailed geologic maps of Wayne County and of similar territory to the north and to the south should enable any practical oil man who will take the trouble to study and understand them to so place his test wells in undeveloped areas as to increase his chances of getting oil between 50 and 75 per cent over the ordinary wildcatting methods. There is every reason to suppose that many 
other profitable oil pools will be found eventually in districts in and adjacent to Wayne County. The structural conditions here seem to favor the practical application of geology in finding these pools.

\section{TECHNOLOGY.}

Most of the drilling to the Beaver Creek "sand" is done with drilling machines. The wells are shallow, ranging from about 400 to 1,000 feet in depth. A single string of $6 \frac{1}{4}$ casing is generally used to shut off all water, which usually occurs above the "Waverly" formation. The cost of drilling a well to the Beaver Creek "sand" and of putting it to pumping ranges from about $\$ 1,000$ to $\$ 2,000$. A large item of this cost is hauling. The oil fields, especially in the southern part of the county, are remote from railroads. Most of the oil-well supplies are brought in to the fields from Burnside, a station on the Queen \& Crescent Railroad; 20 to 40 miles distant.

A good macadamized pike connects Burnside and Monticello, and other roads extend from Monticello to Oil Valley and Cooper. In the mountainous region south of these places the roads are usually very bad, being both steep and rocky.

In some districts considerable difficulty is experienced during dry seasons in procuring a sufficient supply of water. Wood for fuel is plentiful and fairly cheap. Coal is in places available from local coal banks at a reasonable price. Gas engines, to which a number of wells are shackled, are generally used for pumping.

\section{ANALYSES OF OIL FROM WAYNE COUNTY POOLS.}

The following list of analyses of oil from Wayne County is reprinted from "The production of petroleum in 1909" by David T. Day: ${ }^{1}$ 
ANALYSES OF OIL FROM WAYNE COUNTY POOLS.

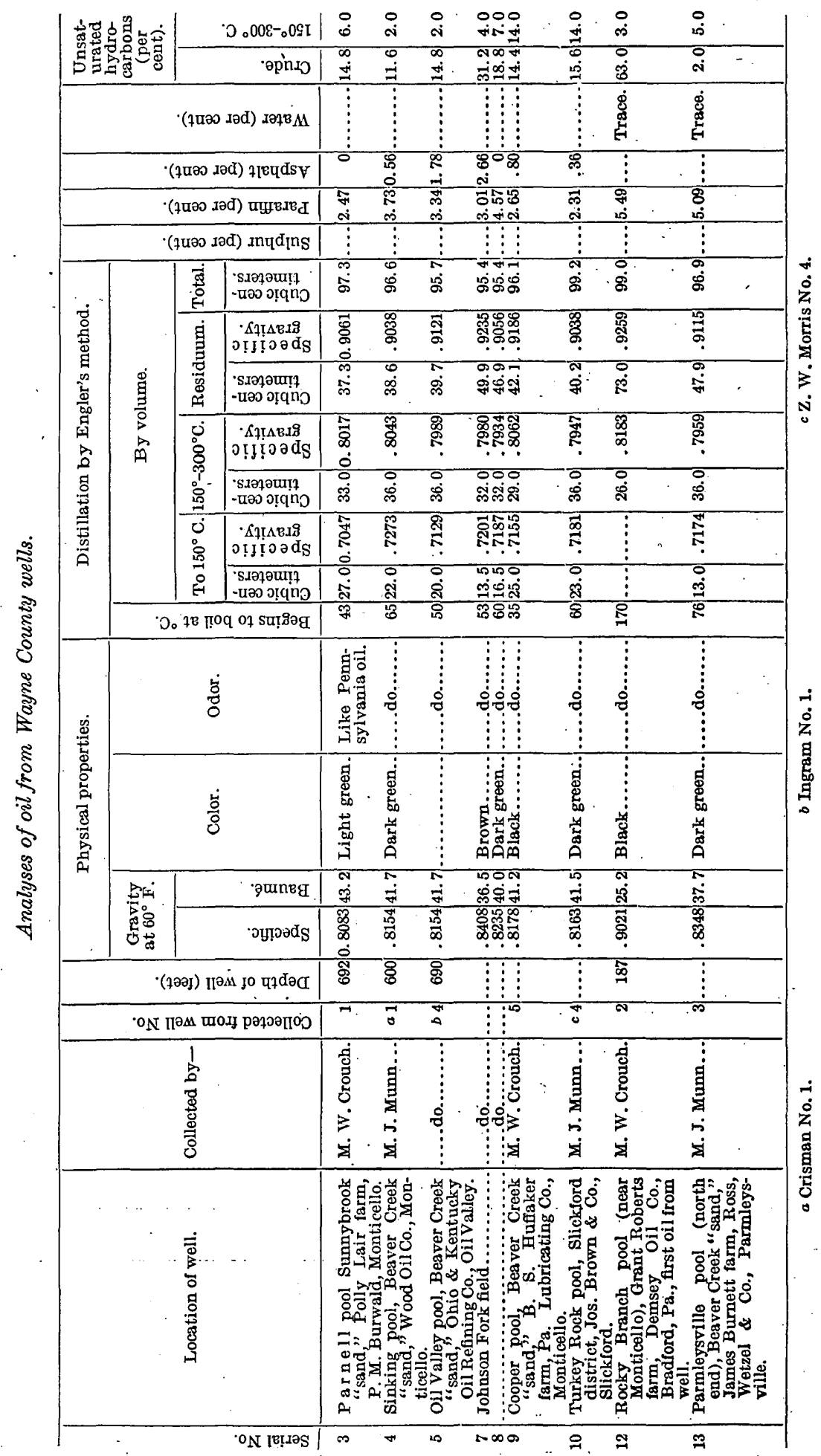

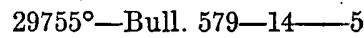




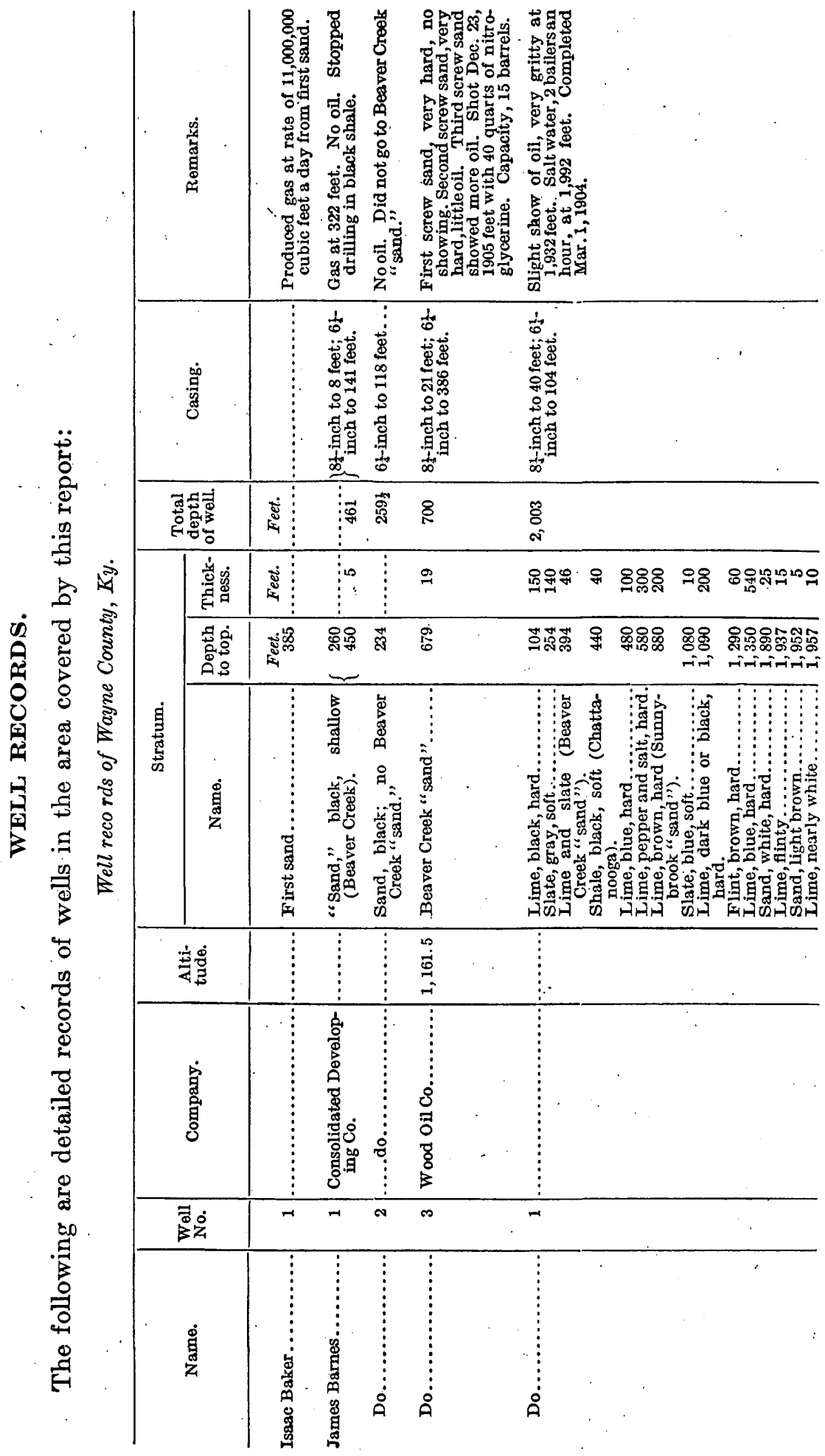


WELL RECORDS.

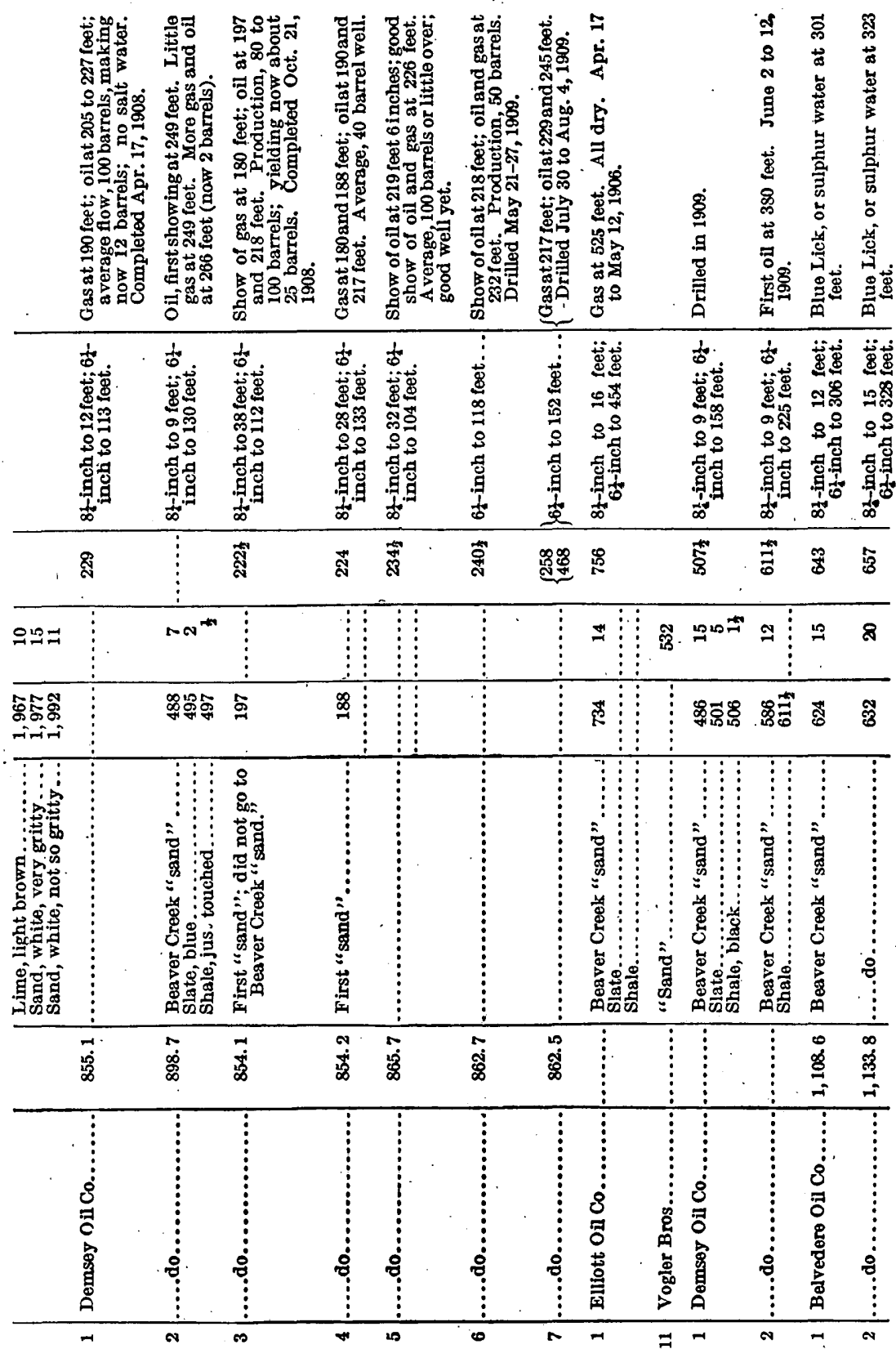

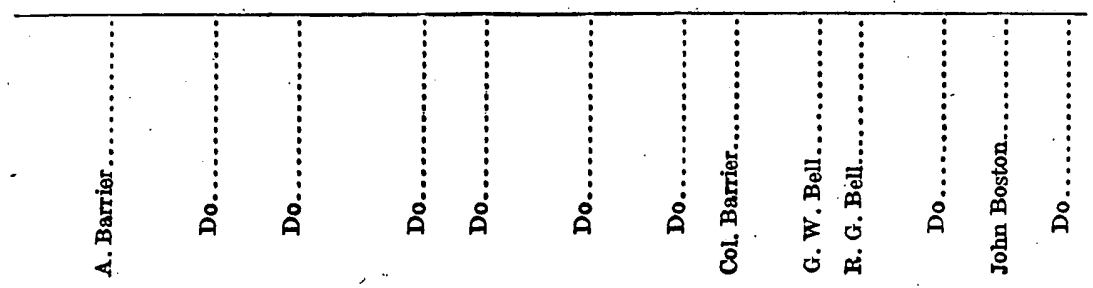




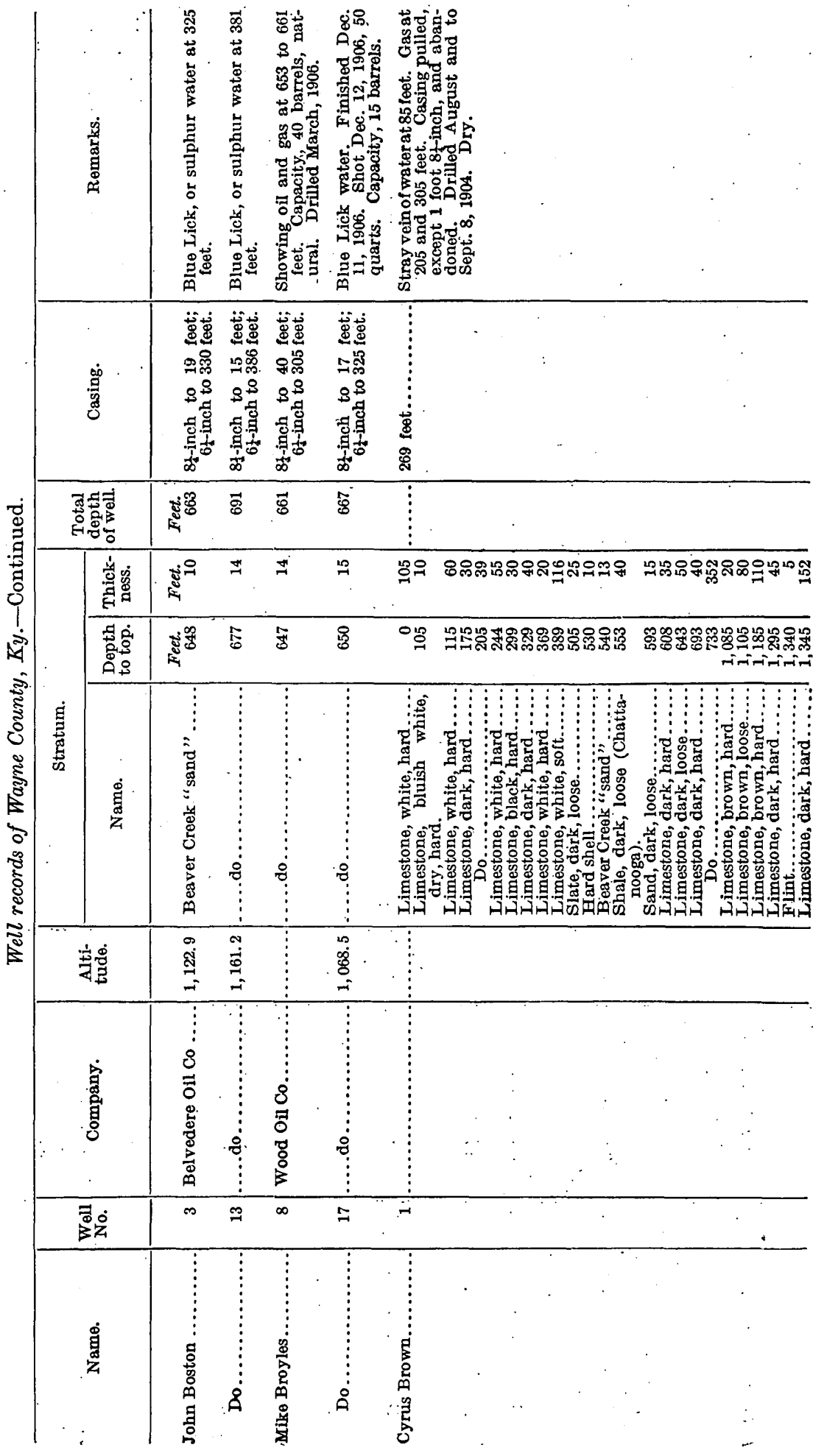


WELL RECORDS:

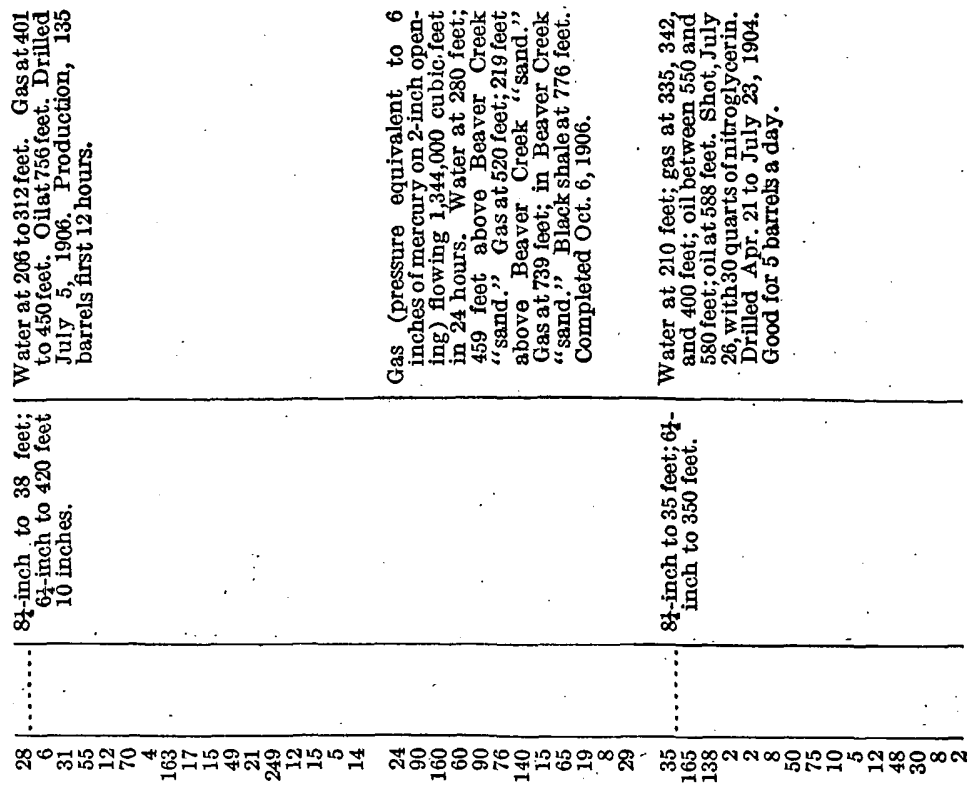

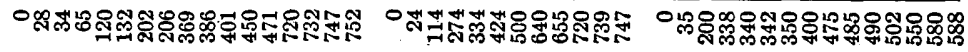

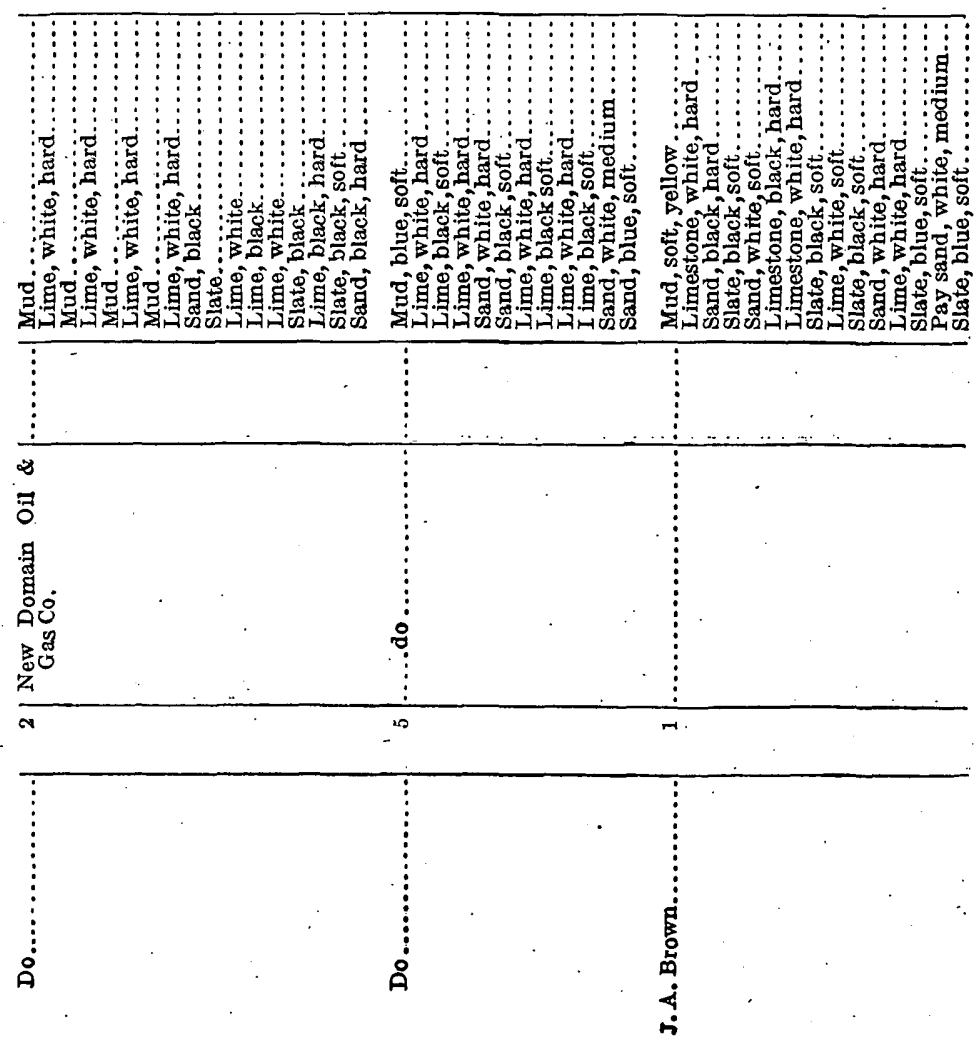


OIL AND GAS IN WAYNE AND MCCREARY COUNTIES, KY.

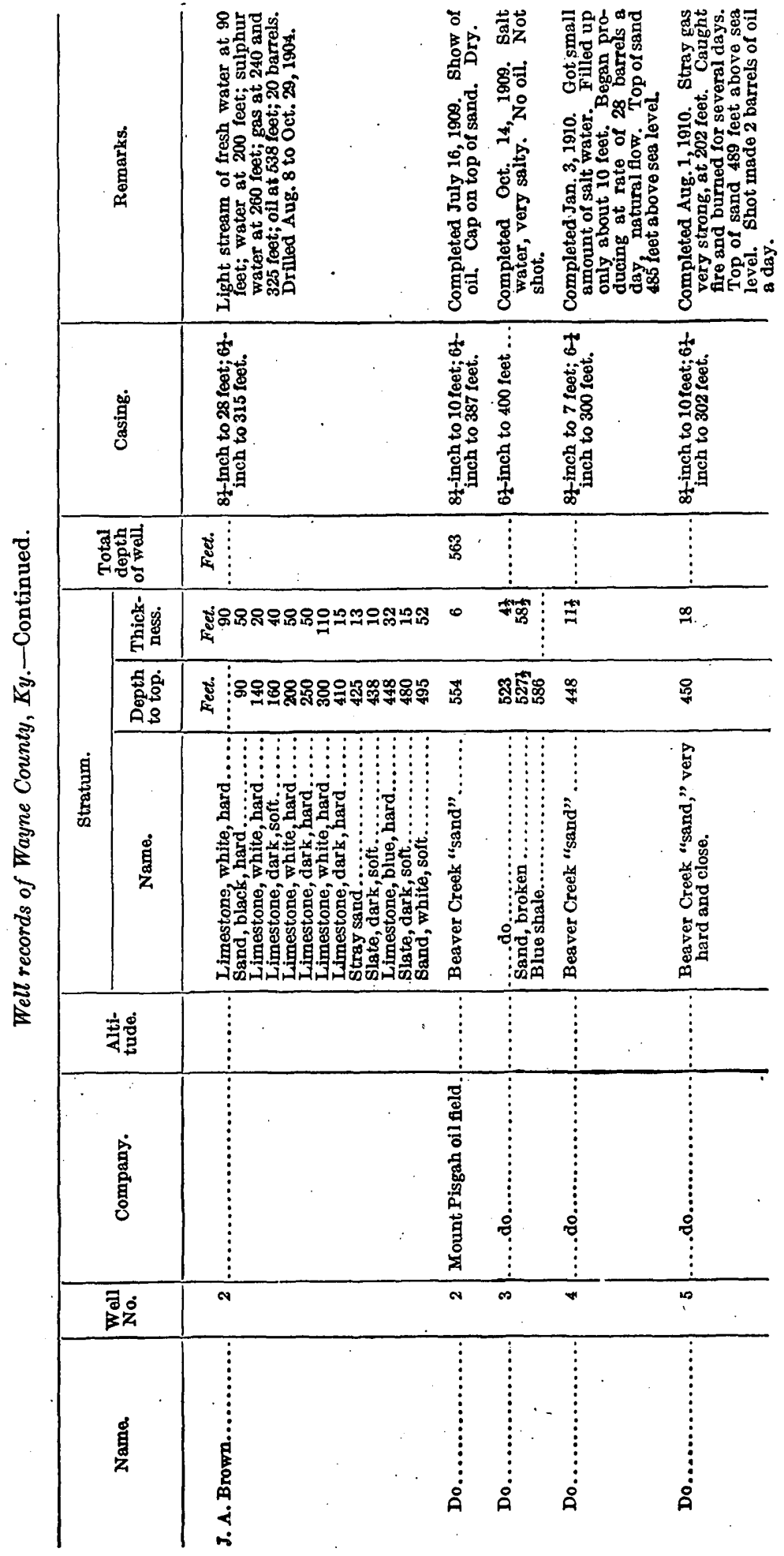


WELL RECORDS.

\begin{tabular}{|c|c|c|c|c|c|c|c|}
\hline 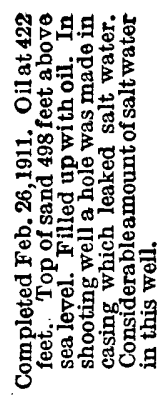 & 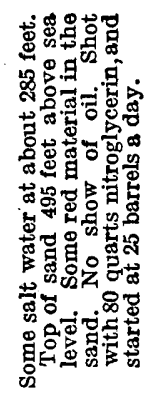 & 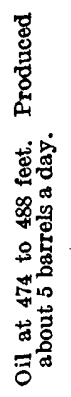 & 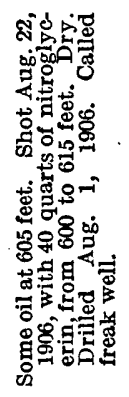 & 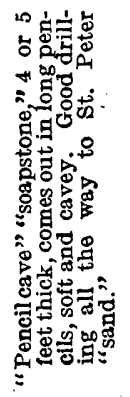 & 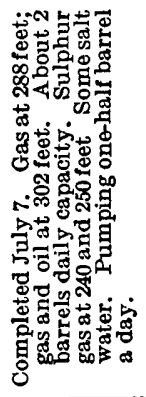 & 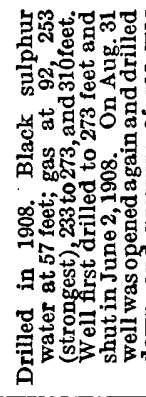 & 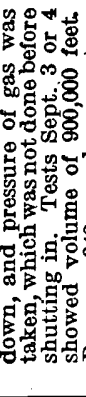 \\
\hline 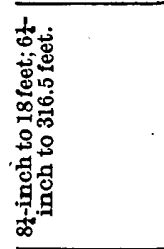 & 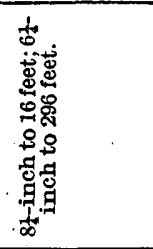 & 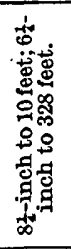 & 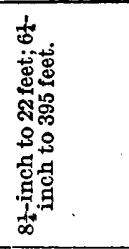 & $\begin{array}{c}\vdots \\
\vdots \\
\vdots \\
\vdots \\
\vdots\end{array}$ & 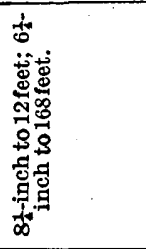 & $\begin{array}{c}\vdots \\
\vdots \\
\vdots \\
\vdots \\
\vdots\end{array}$ & \\
\hline$\tilde{\mathscr{F}}$ & & ஜ্హ & $\underset{\infty}{\infty}$ & 灾 & 蒡 & 茫 & \\
\hline 오고 & 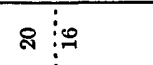 & & రిల్ల & ฟรง & & $8-4$ & \\
\hline 䑳 & 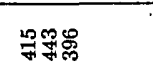 & 함워 & 禺: & 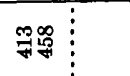 & & ణ్యార్లి & \\
\hline 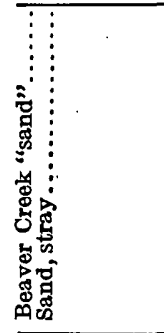 & 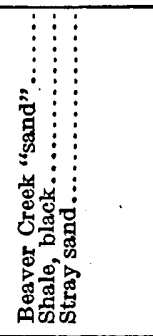 & 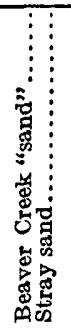 & 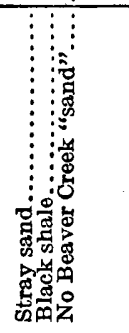 & 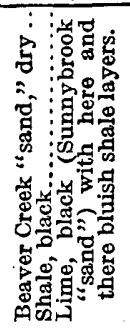 & 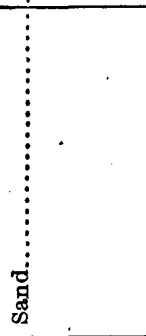 & 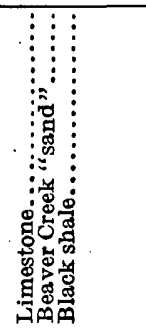 & \\
\hline $\bar{\vdots}$ & $\vdots$ & & & & है & & \\
\hline : ڤْْ & $\begin{array}{r}\vdots \\
\vdots \\
\vdots \\
\vdots \\
\vdots \\
\vdots \\
\vdots \\
\hdashline \\
\hdashline\end{array}$ & $\begin{array}{c}\vdots \\
\vdots \\
\vdots \\
\end{array}$ & $\begin{array}{l}\vdots \\
\vdots \\
8 \\
7 \\
0 \\
0 \\
8 \\
8\end{array}$ & $\begin{array}{c}\vdots \\
\vdots \\
\vdots \\
\vdots \\
\vdots \\
\vdots\end{array}$ & 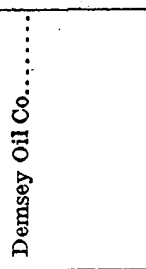 & 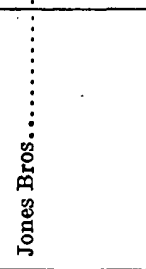 & \\
\hline & & & & & & & \\
\hline
\end{tabular}

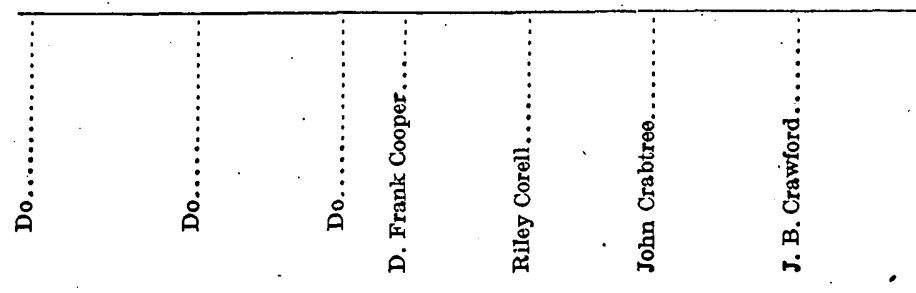


OIL AND GAS IN WAYNE AND MCCREARY COUNTIES, KY.

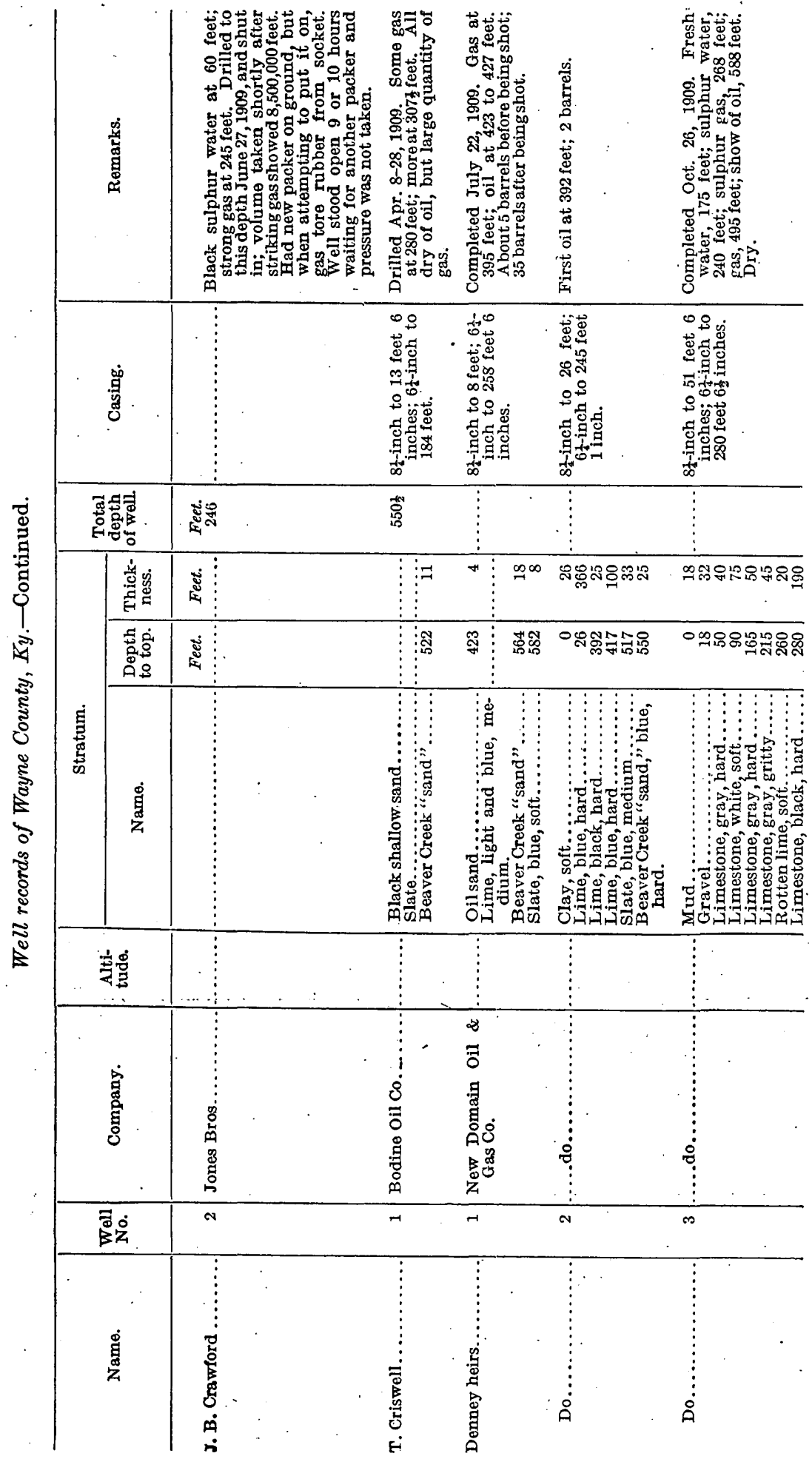




\begin{tabular}{|c|c|c|}
\hline 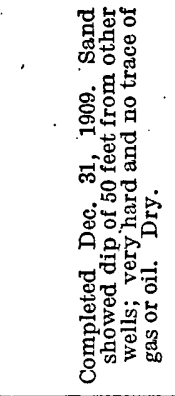 & 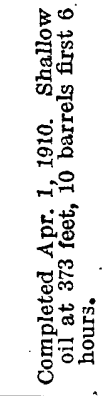 & 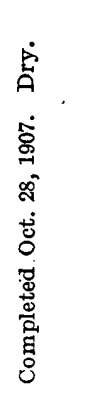 \\
\hline 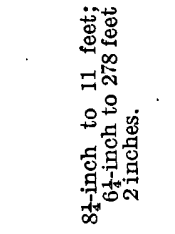 & 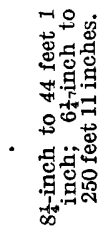 & 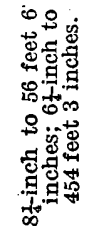 \\
\hline
\end{tabular}

\begin{tabular}{|c|c|c|c|}
\hline . & : & &. \\
\hline 요유묘 & 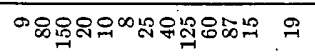 & 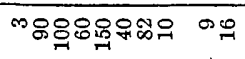 & 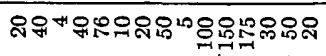 \\
\hline
\end{tabular}
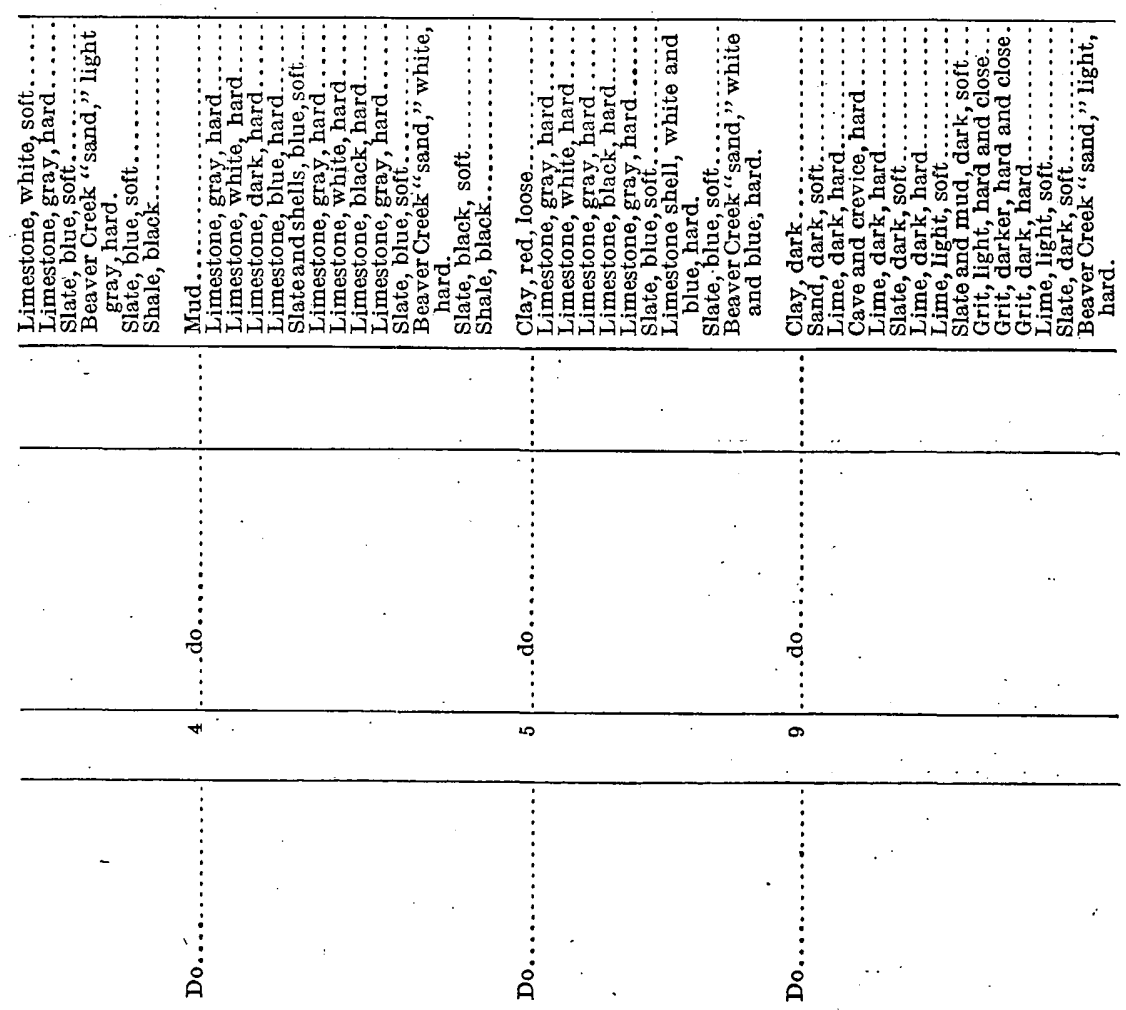

OIL AND GAS IN WAYNE AND MCCREARY COUNTIES, KY.

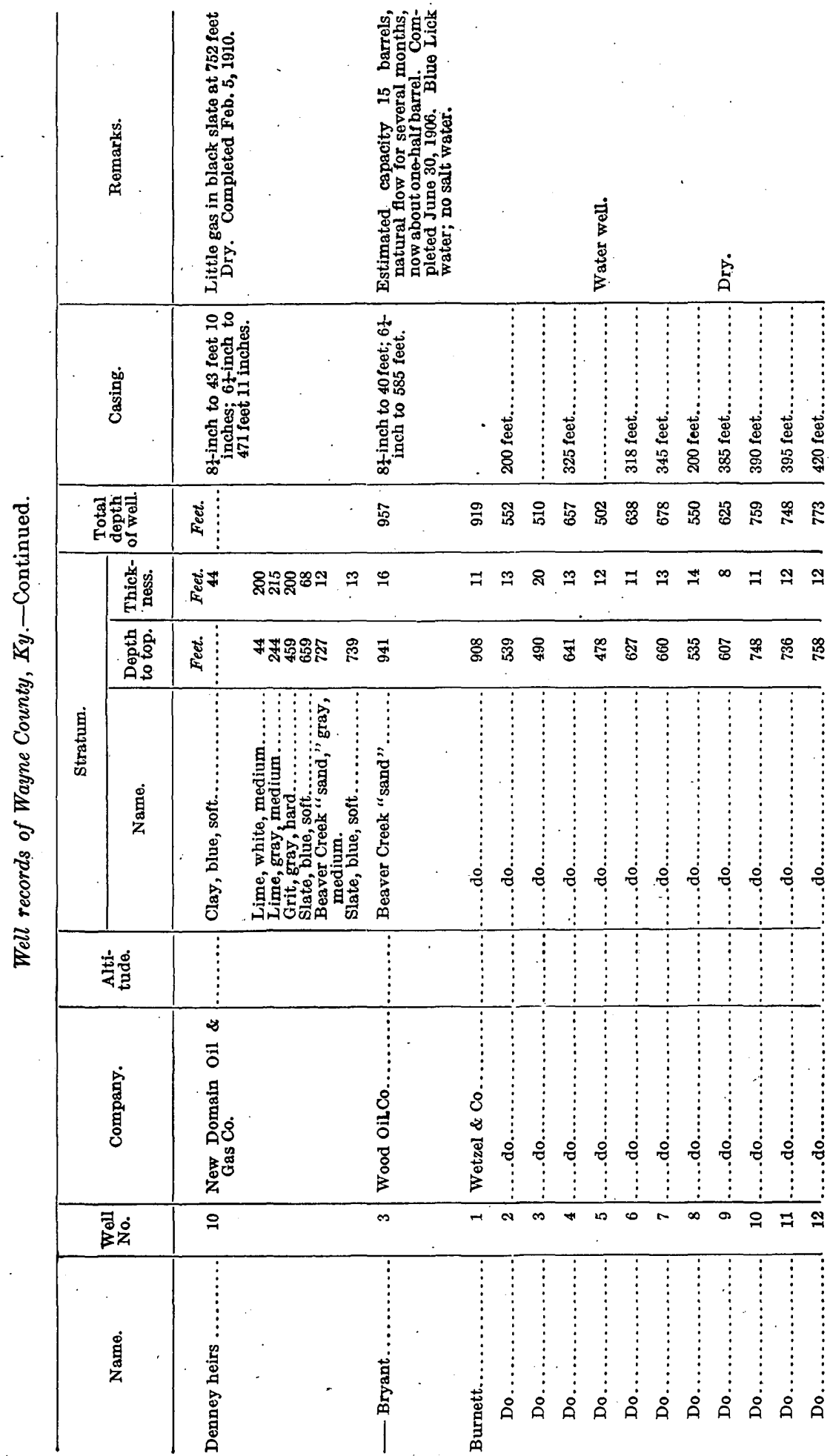



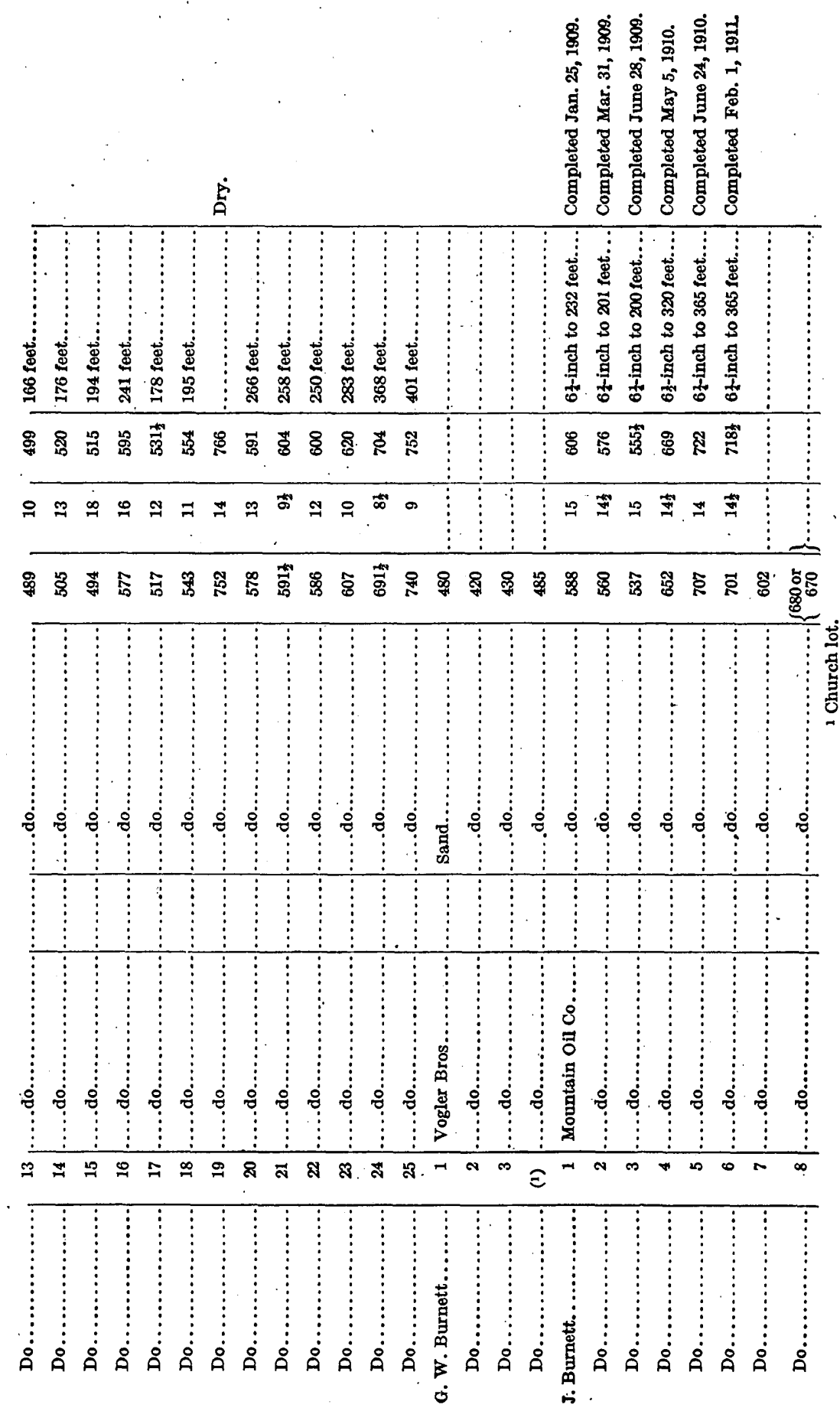
74 OIL AND GAS IN WAYNE AND MCCREARY COUNTIES, KY.

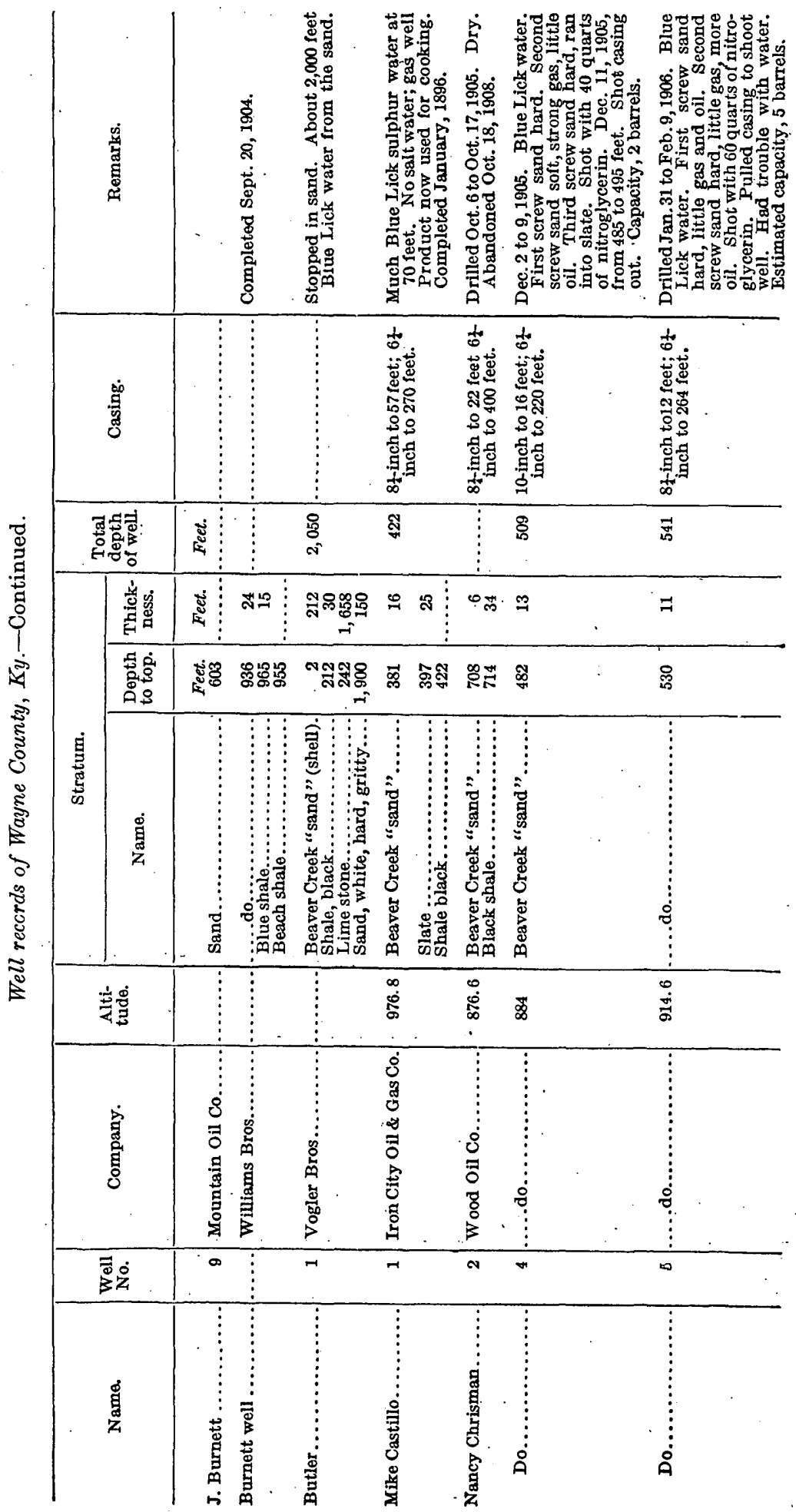


WELL RECORDS.
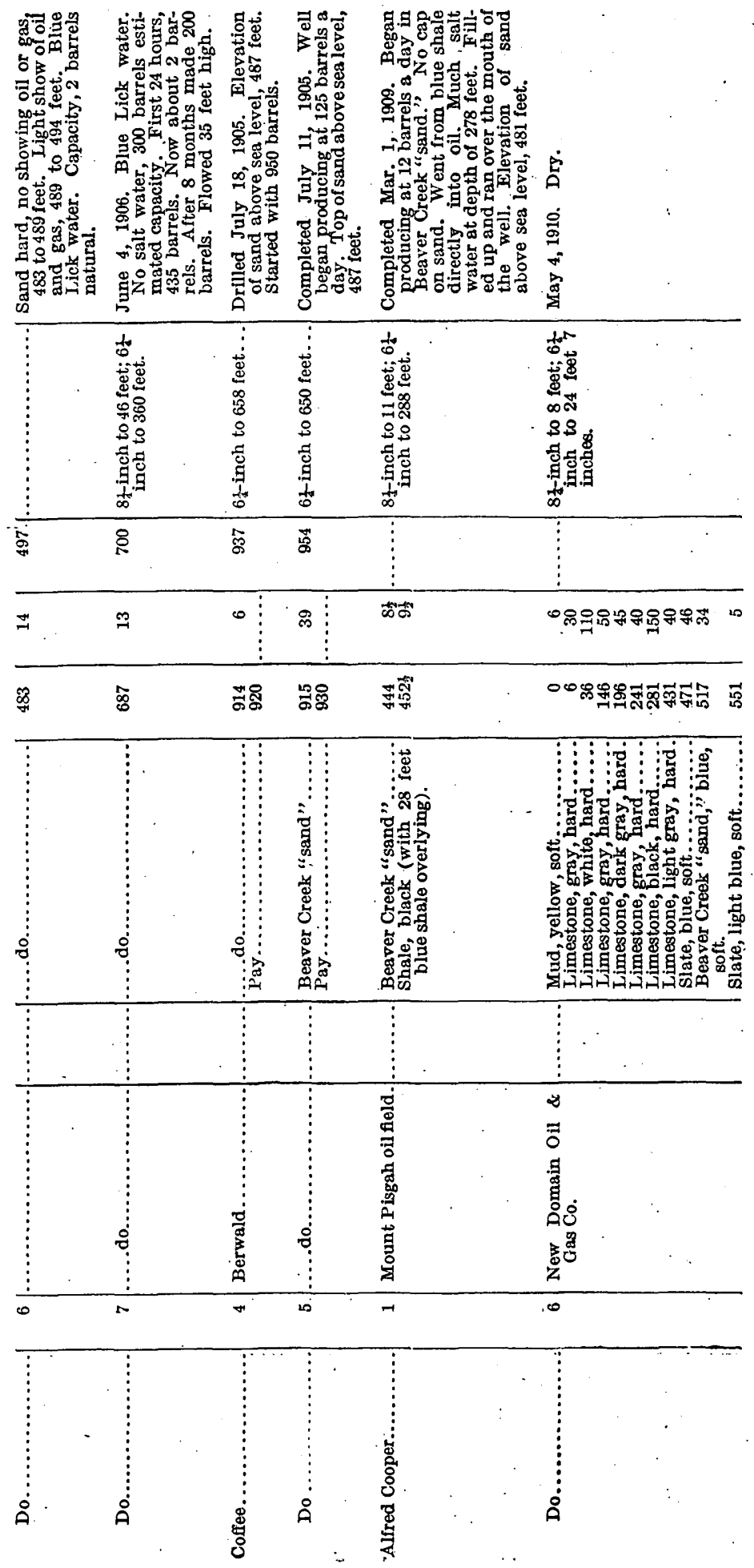


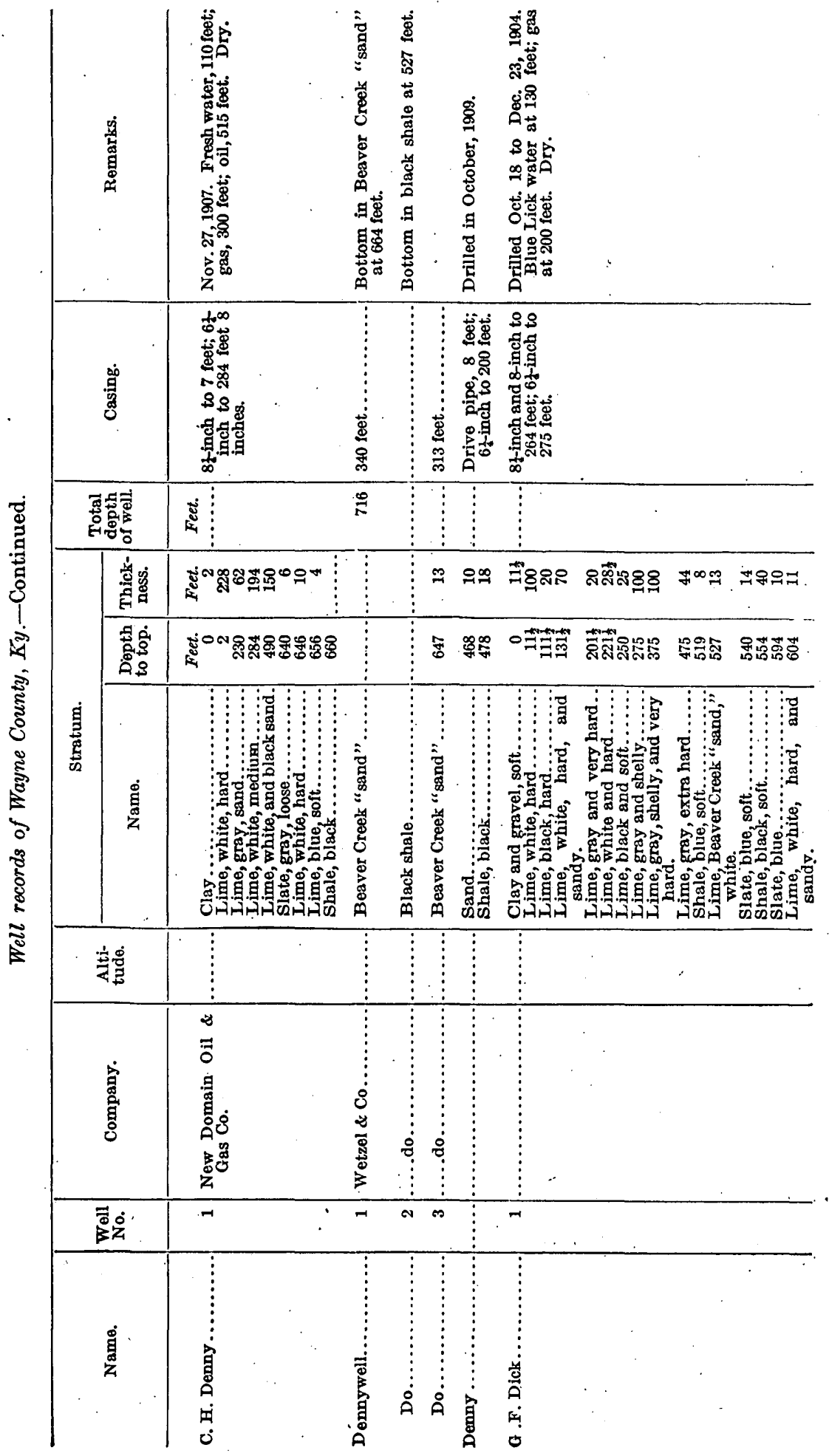


WELL RECORDS.

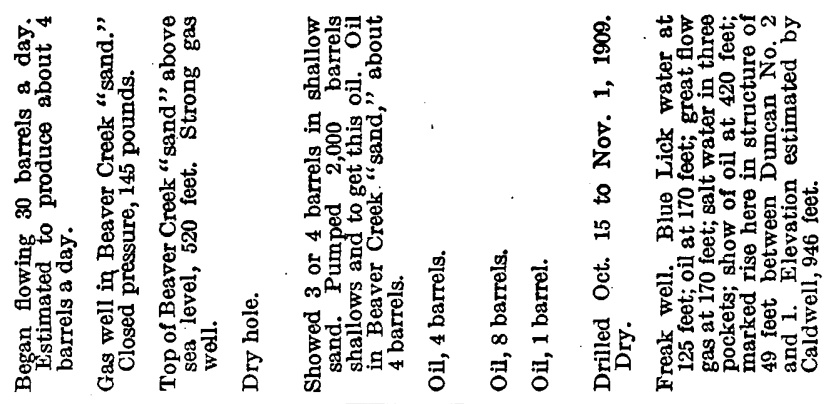

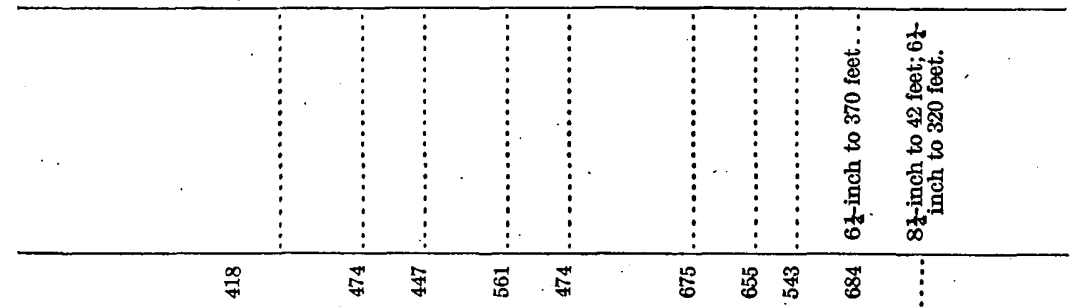

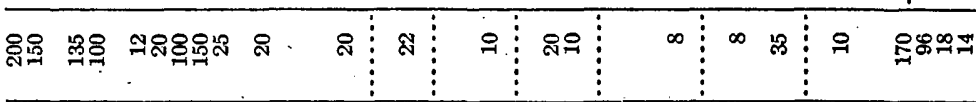

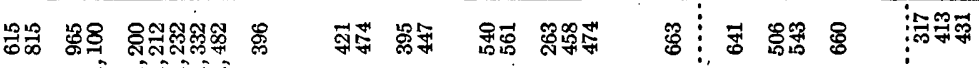
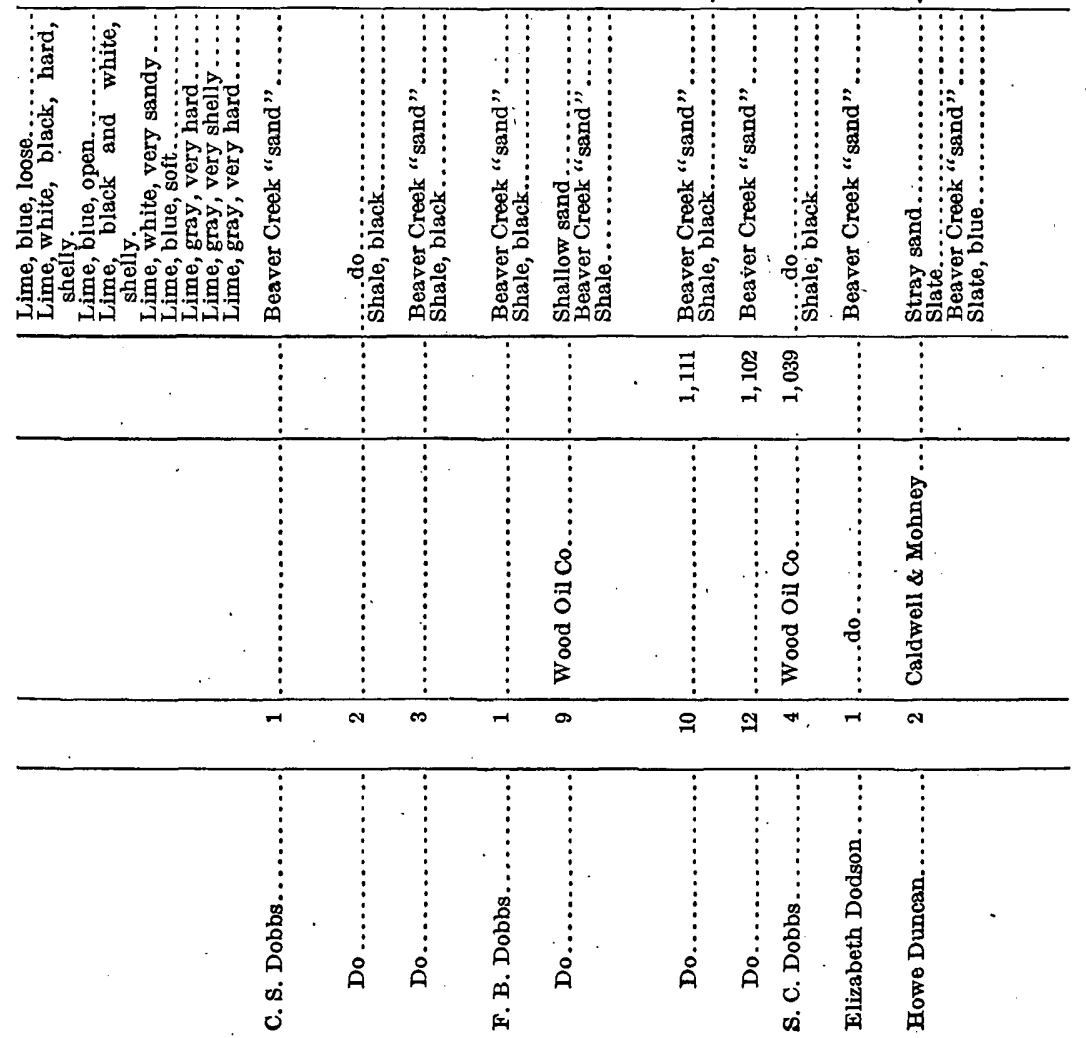
OIL AND GAS IN WAYNE AND MCCREARY COUNTIES, KY.

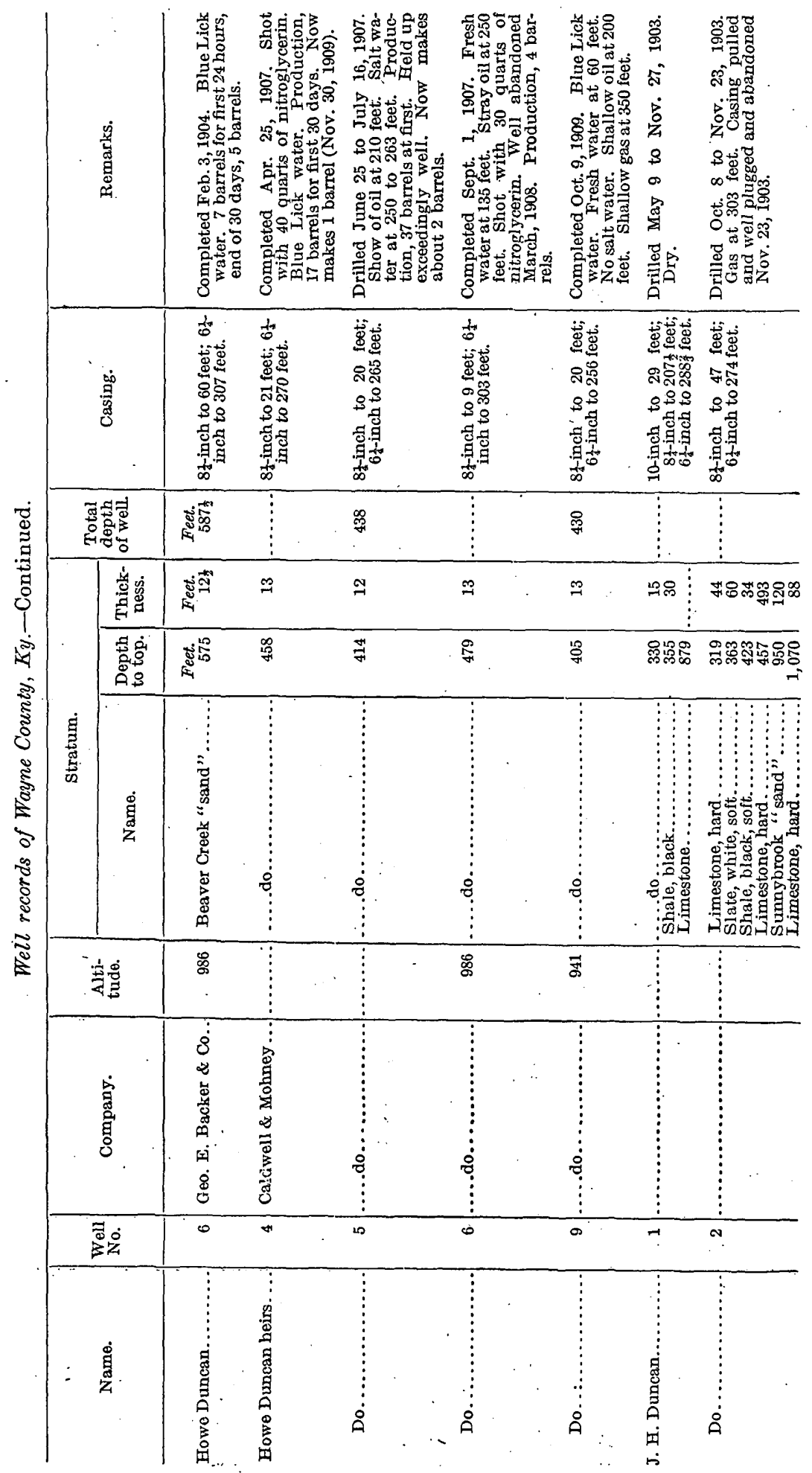




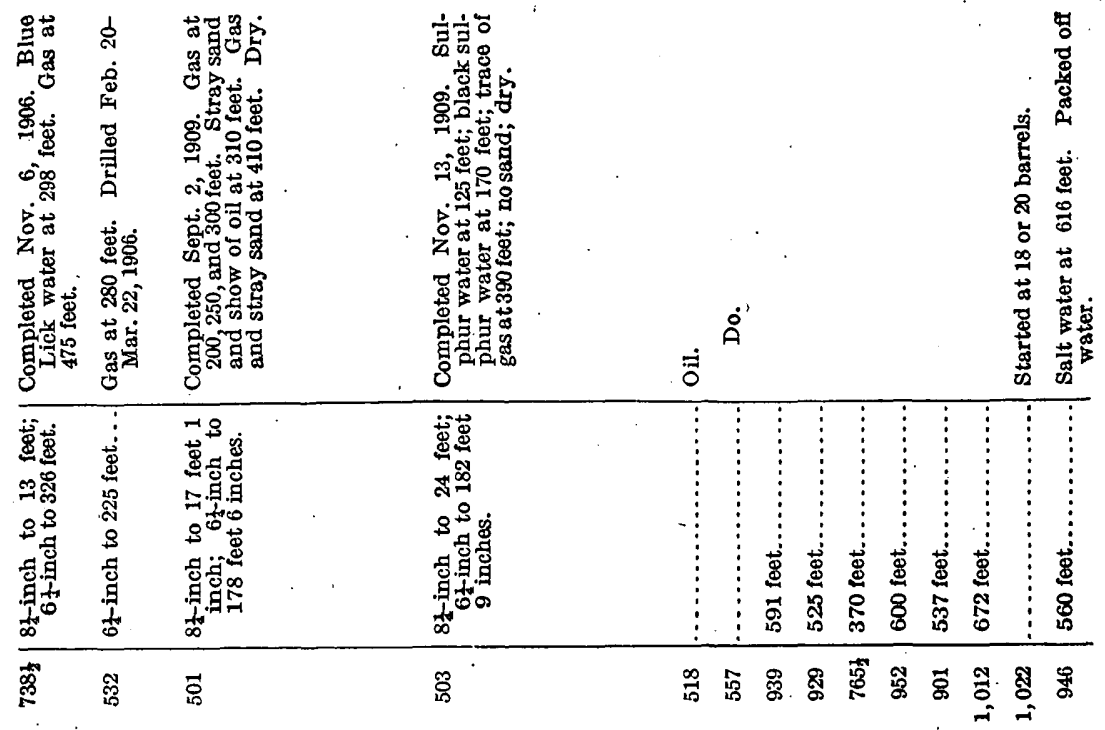

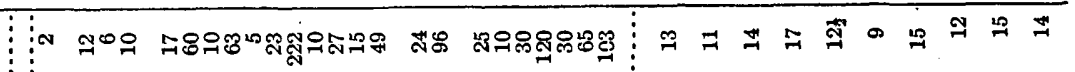

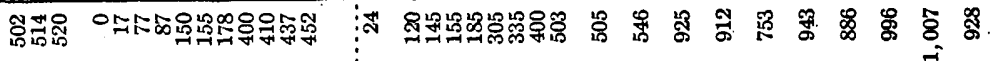

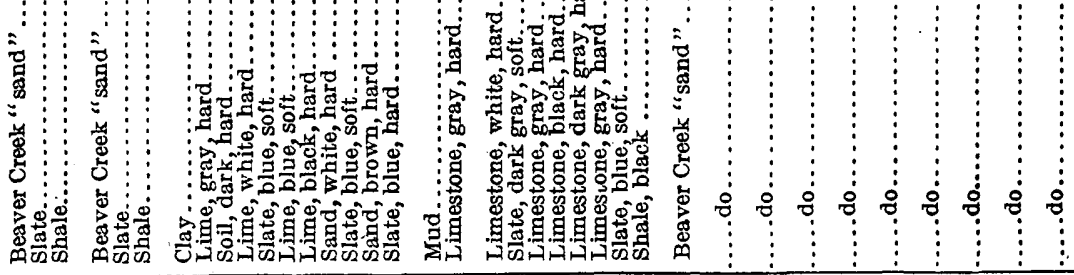
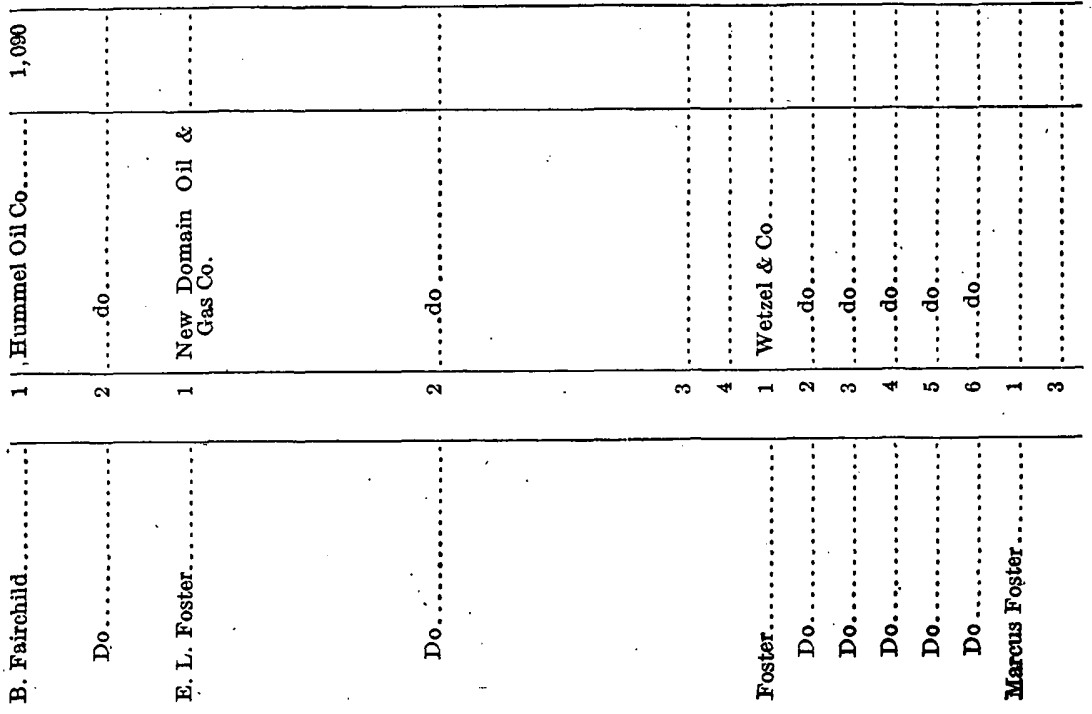


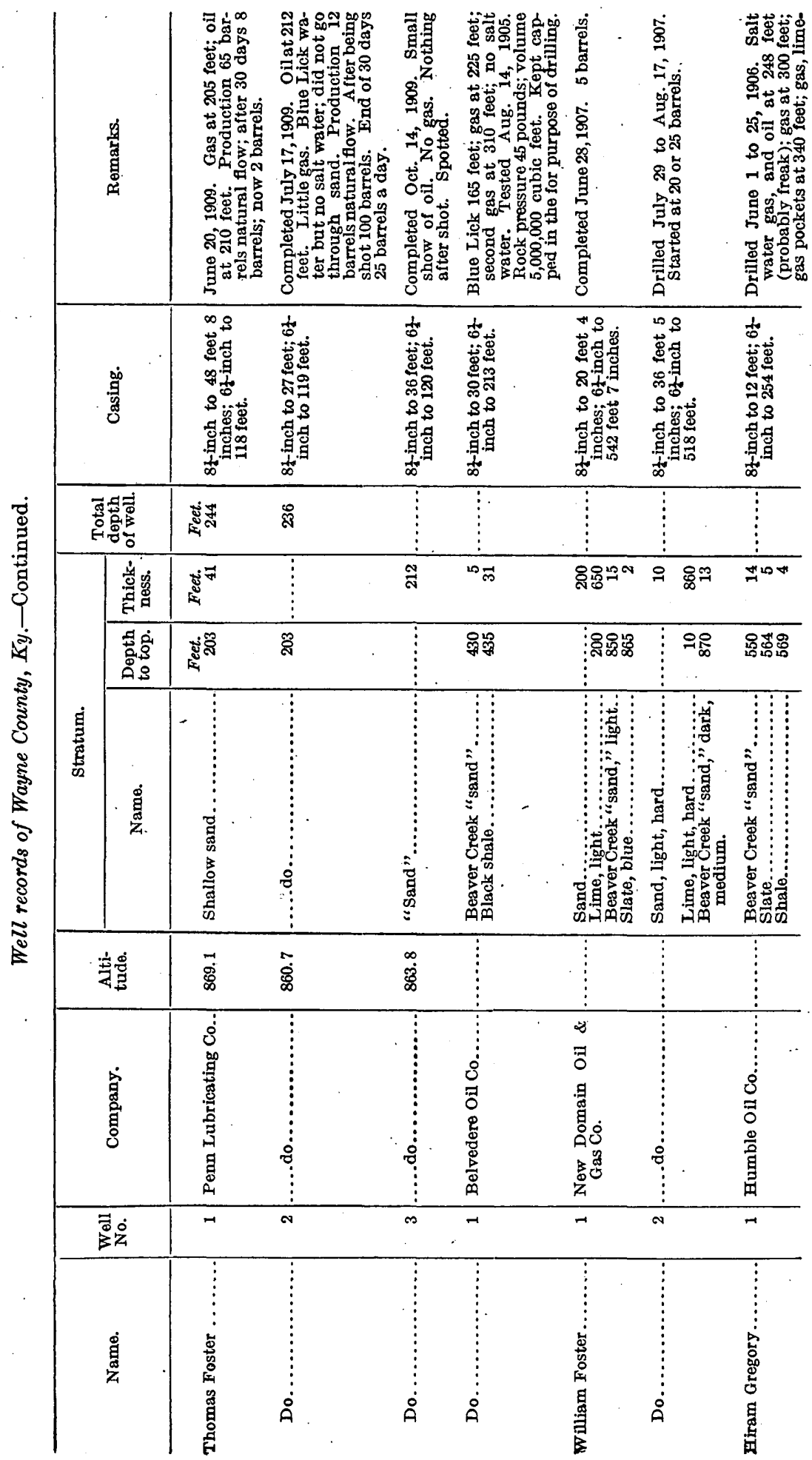




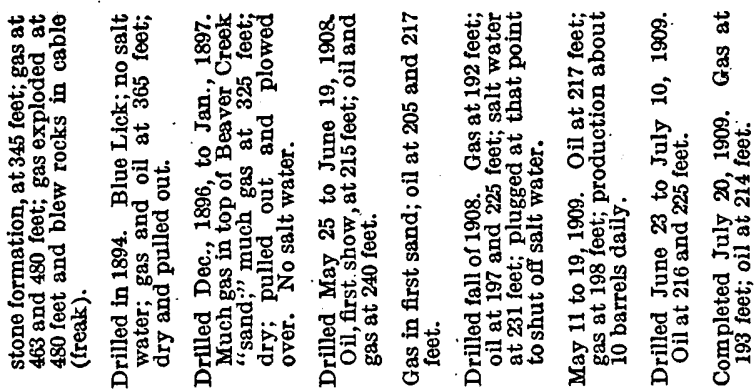

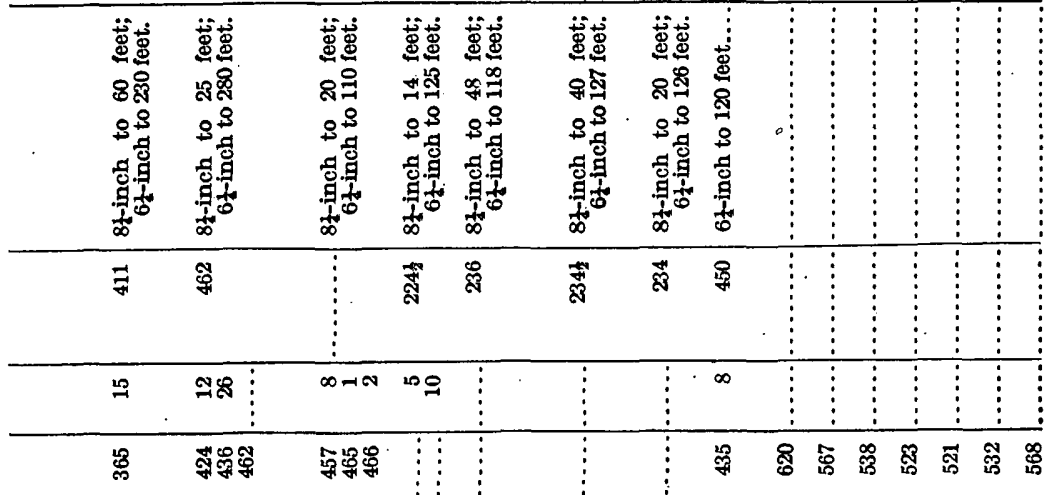

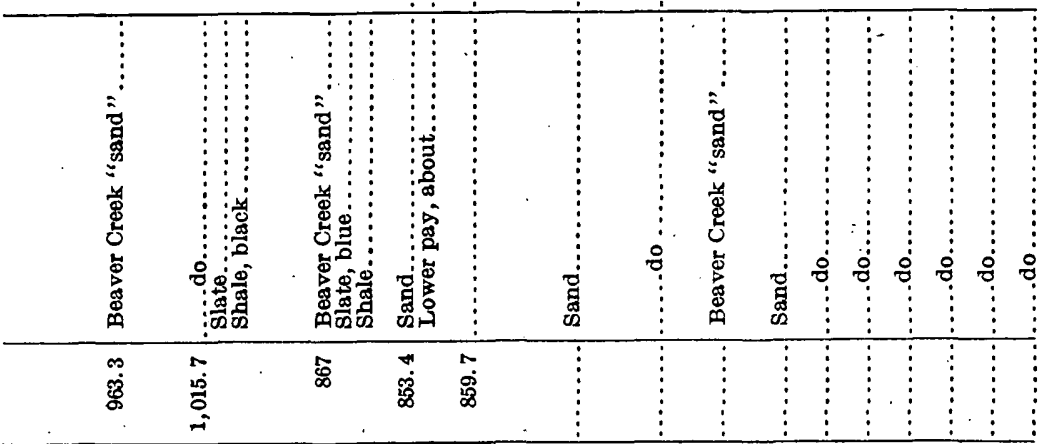

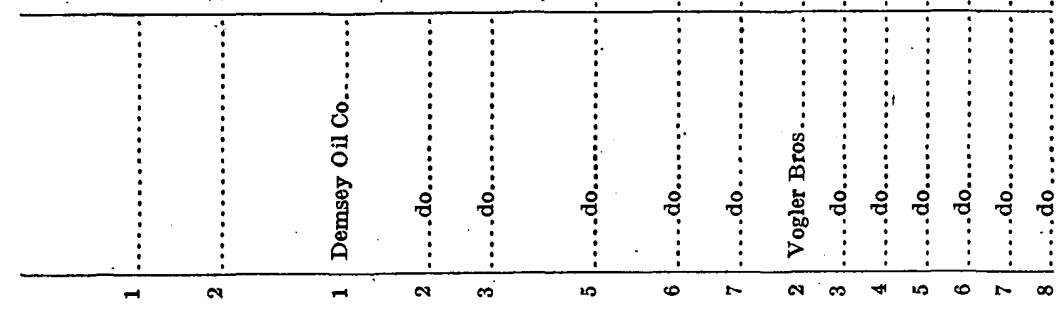

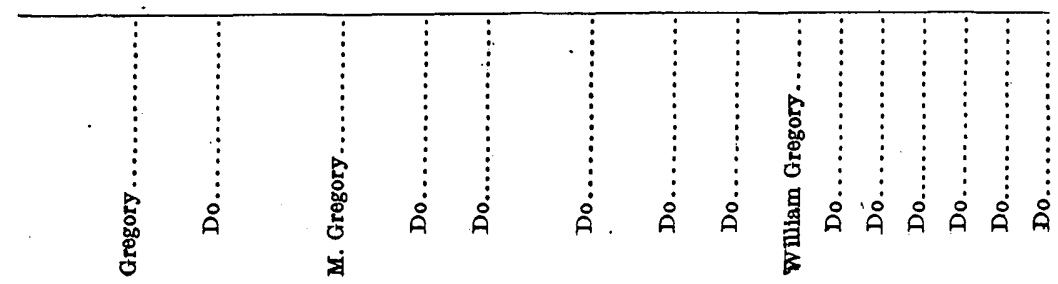


82 OIL AND GAS IN WAYNE AND MCCREARY COUNTIES, KY.

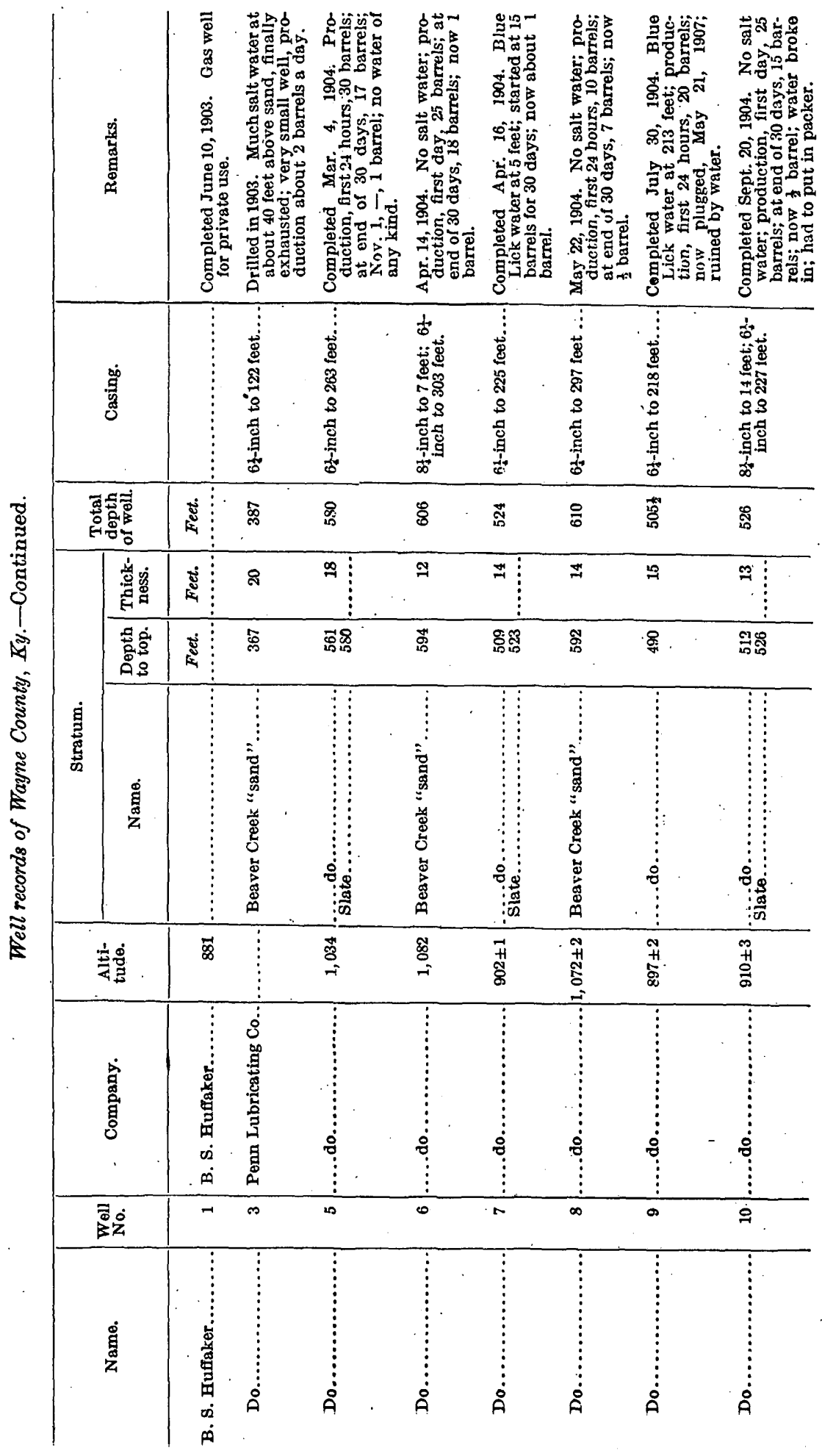


WELI RECORDS.

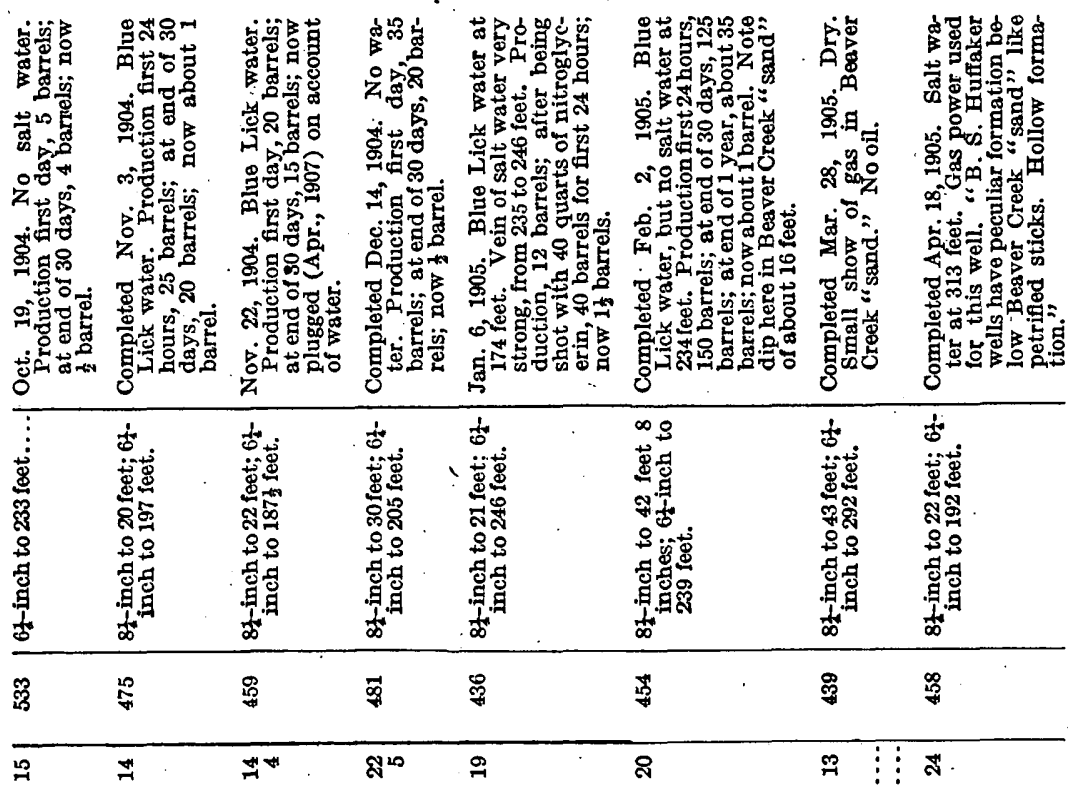

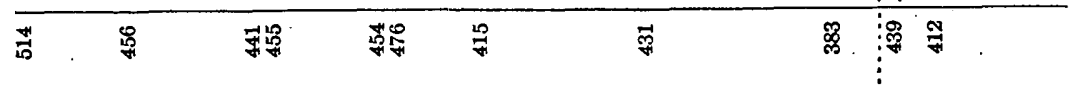

\begin{tabular}{|c|c|c|c|c|c|c|c|}
\hline 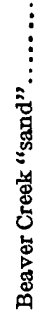 & $\begin{array}{c}\vdots \\
\vdots \\
\vdots \\
\vdots \\
\vdots \\
\vdots \\
\vdots \\
\vdots \\
\vdots\end{array}$ & 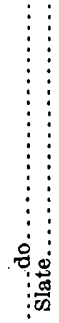 & 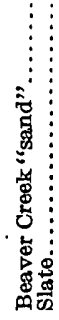 & 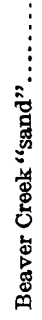 & $\begin{array}{c}\vdots \\
0 \\
0 \\
\vdots \\
\vdots \\
0 \\
0\end{array}$ & 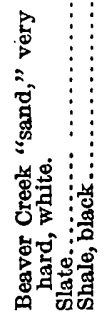 & 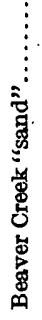 \\
\hline$\stackrel{8}{8}$ & $\begin{array}{l}\text { T్ } \\
\text { 芯 }\end{array}$ & 辛 & $\underset{\infty}{\stackrel{5}{*}}$ & $\stackrel{100}{\infty}$ & హี & \begin{tabular}{l} 
N \\
\# \\
\multirow{2}{*}{}
\end{tabular} & $\begin{array}{l}\text { an } \\
\text { s. } \\
\text { s. }\end{array}$ \\
\hline
\end{tabular}
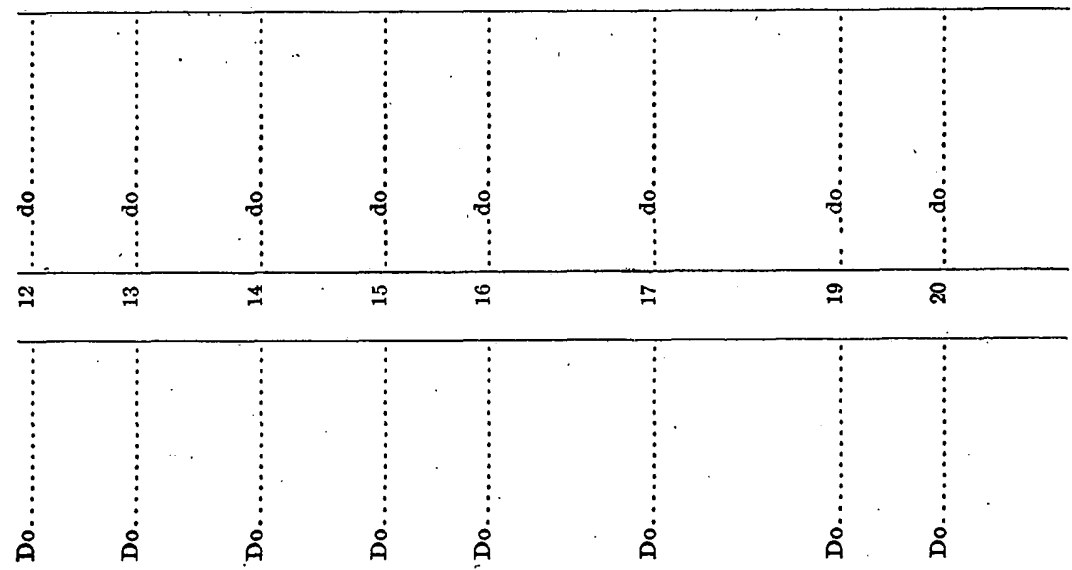
84 OIL AND GAS IN WAYNE AND MCCREARY COUNTIES, KY.

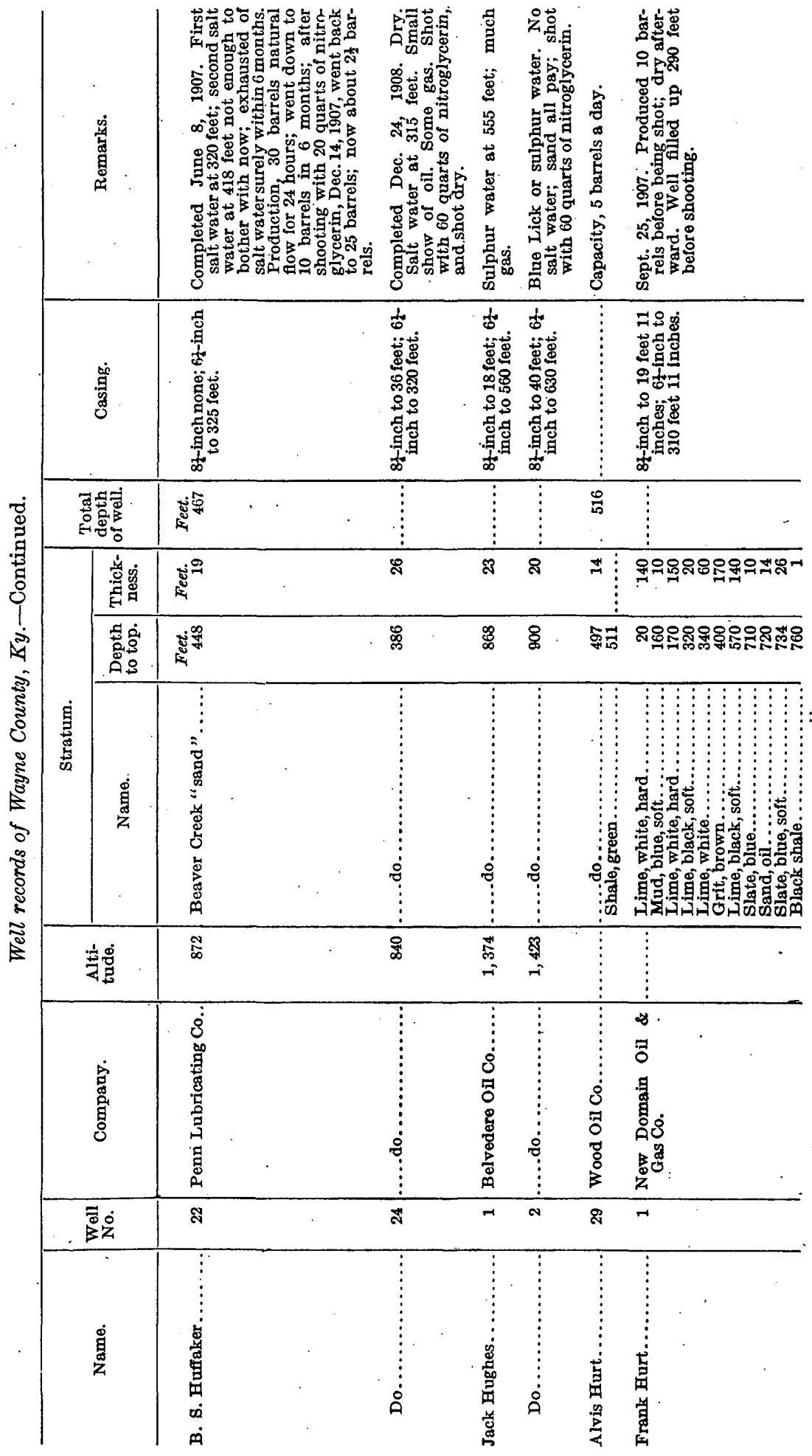


WELL RECORDS.

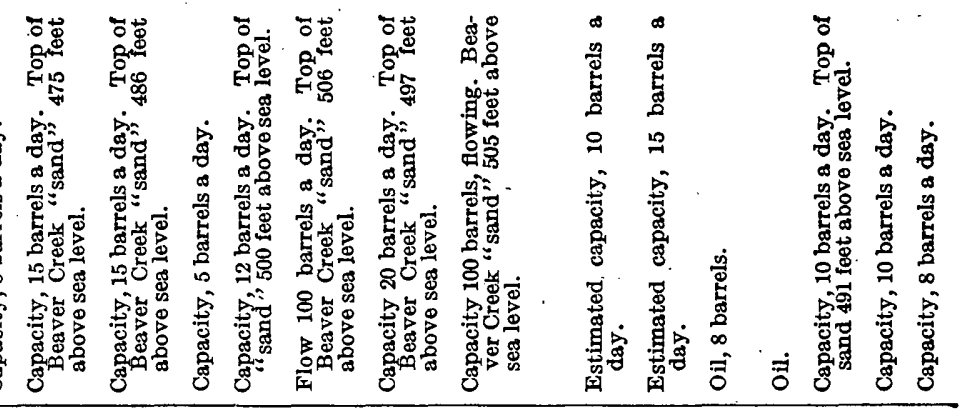

敢

잉 0 워

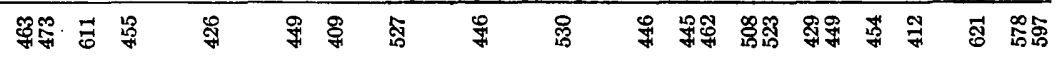
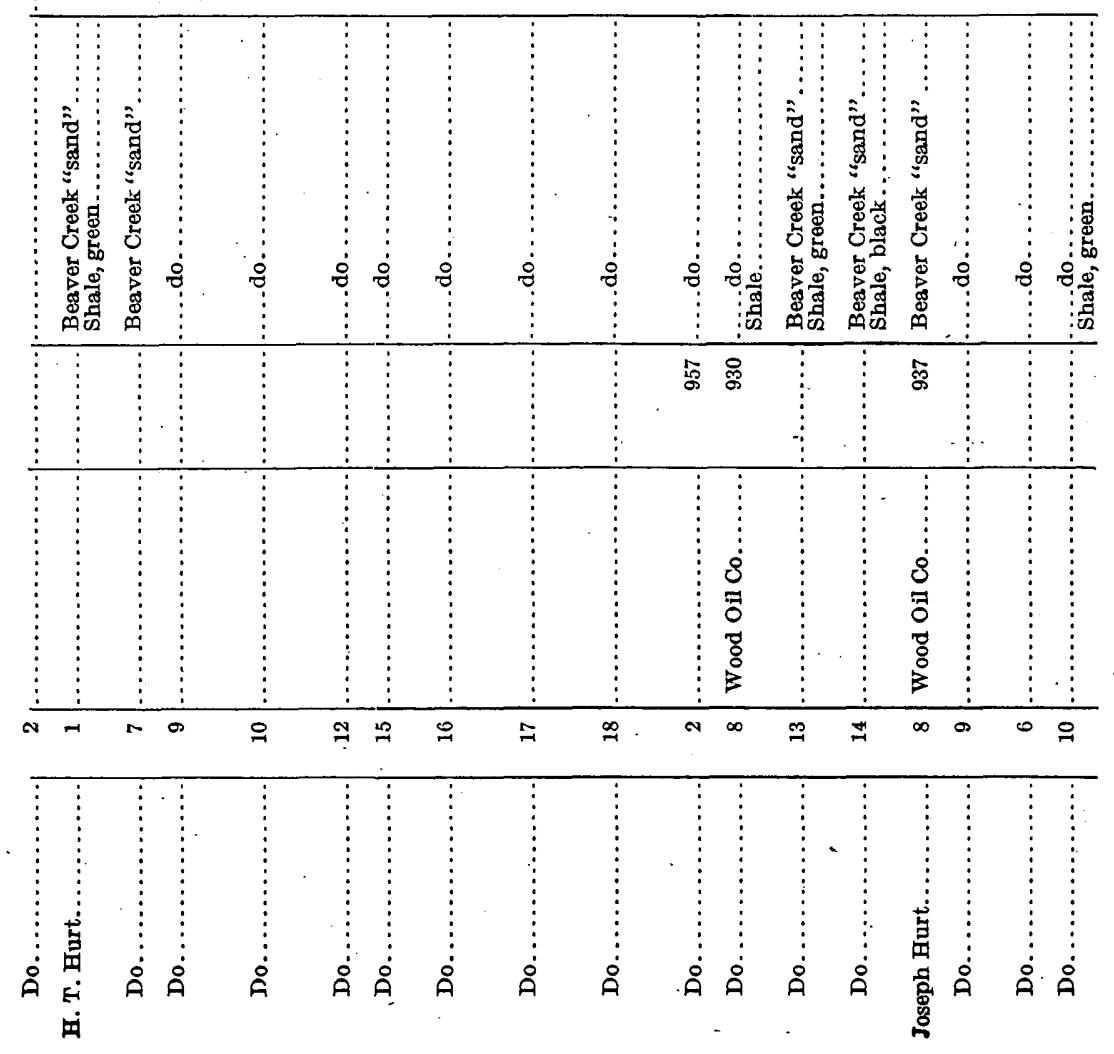


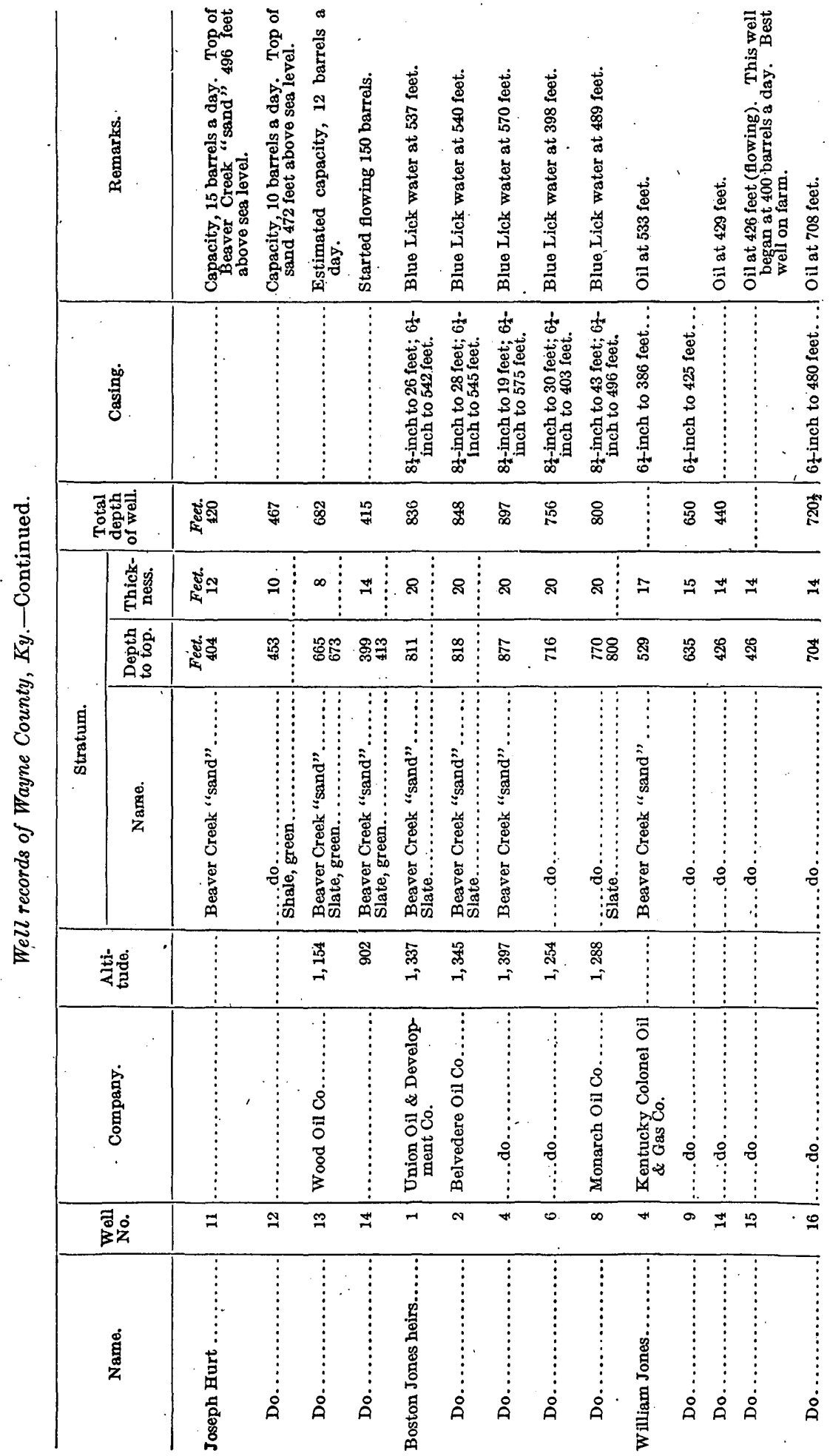




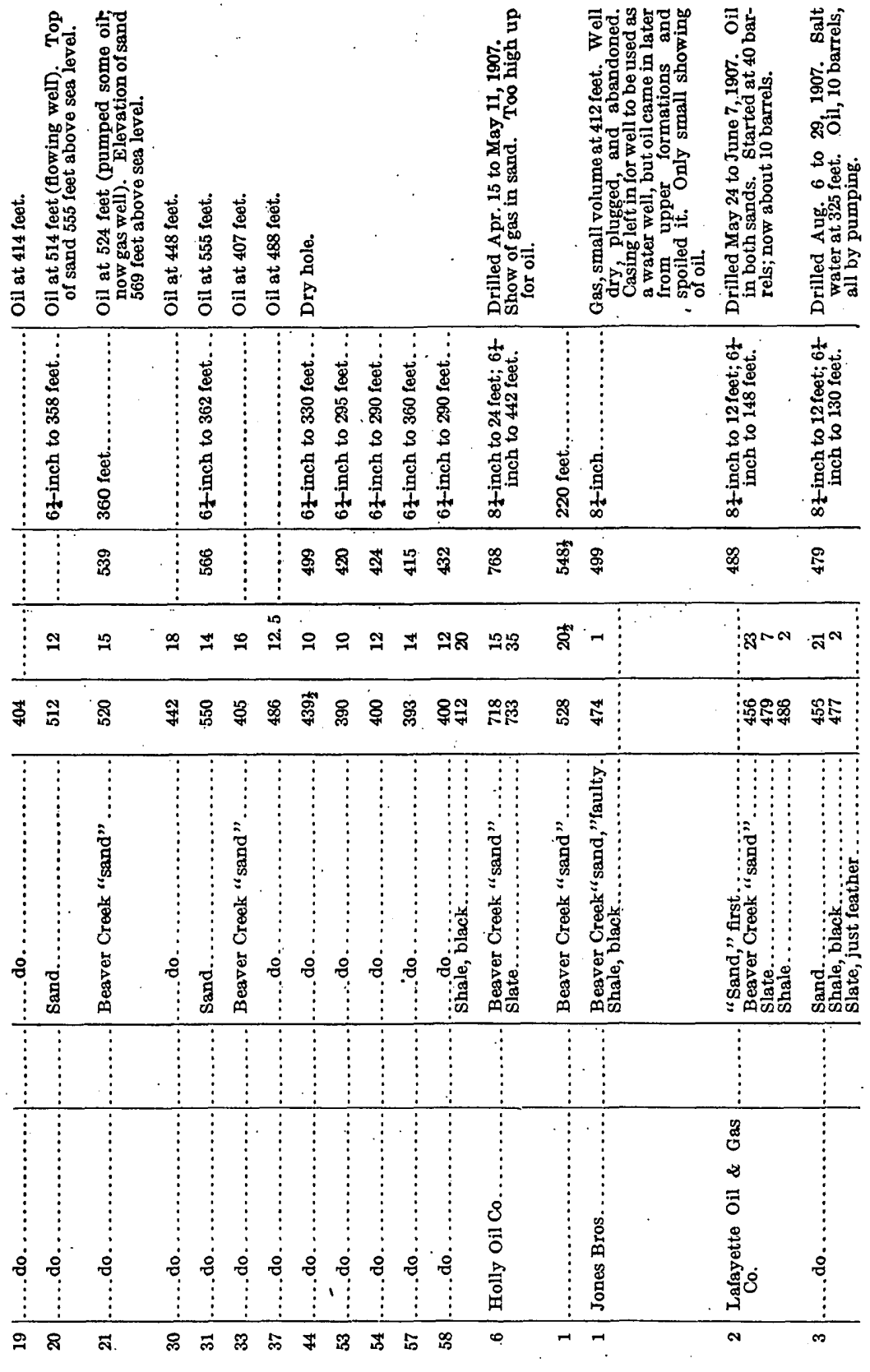

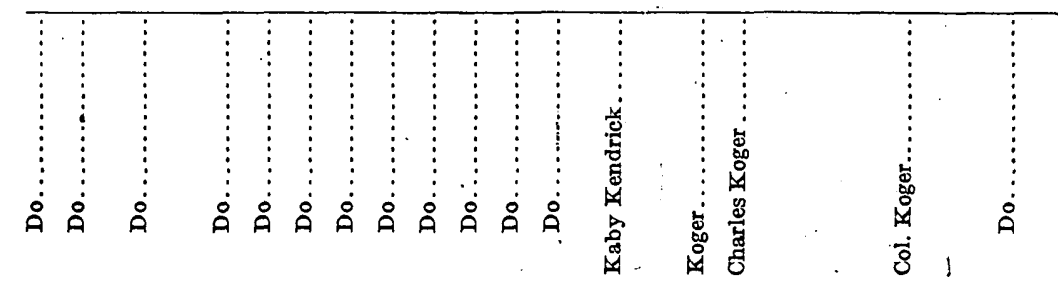




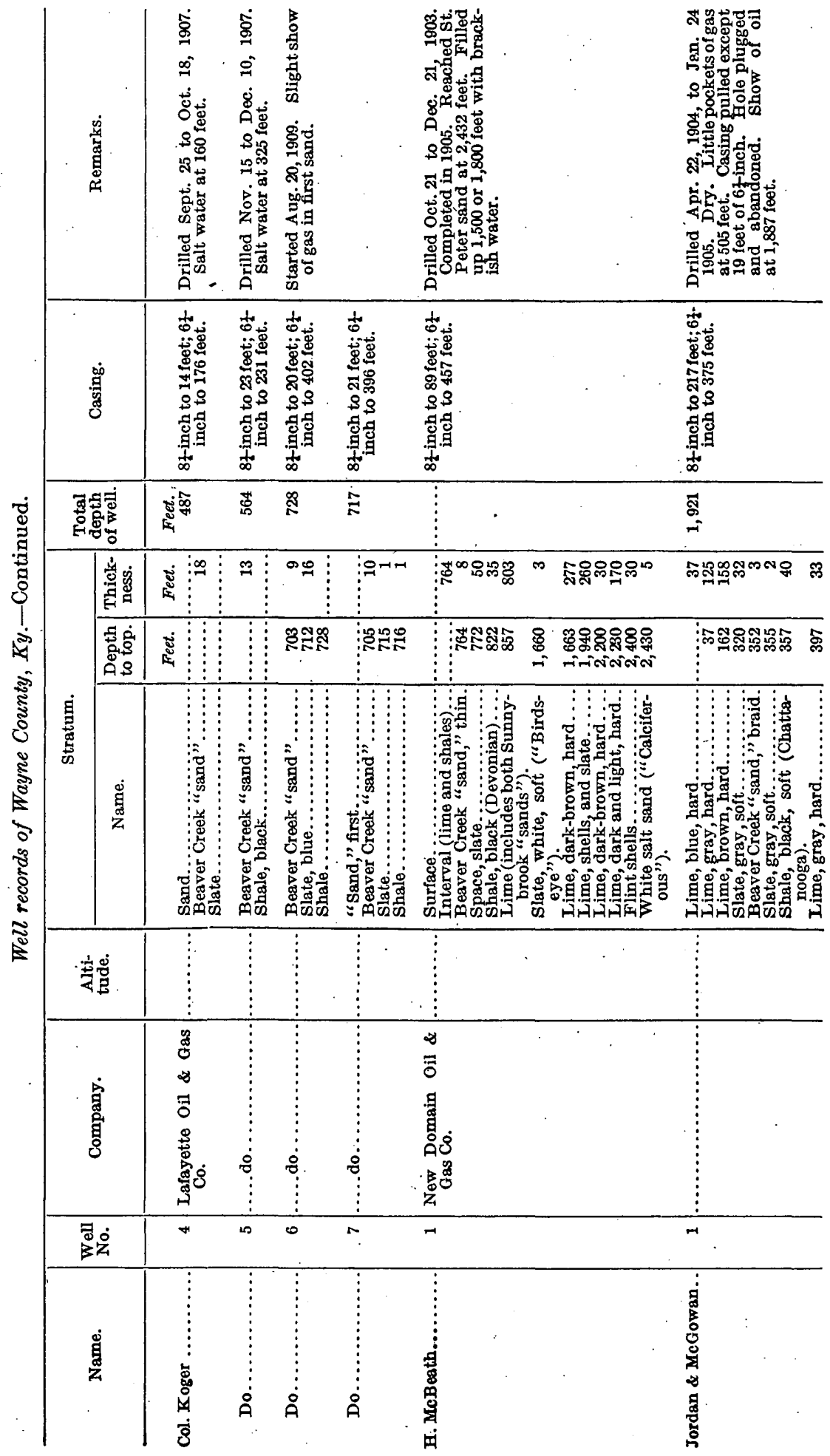




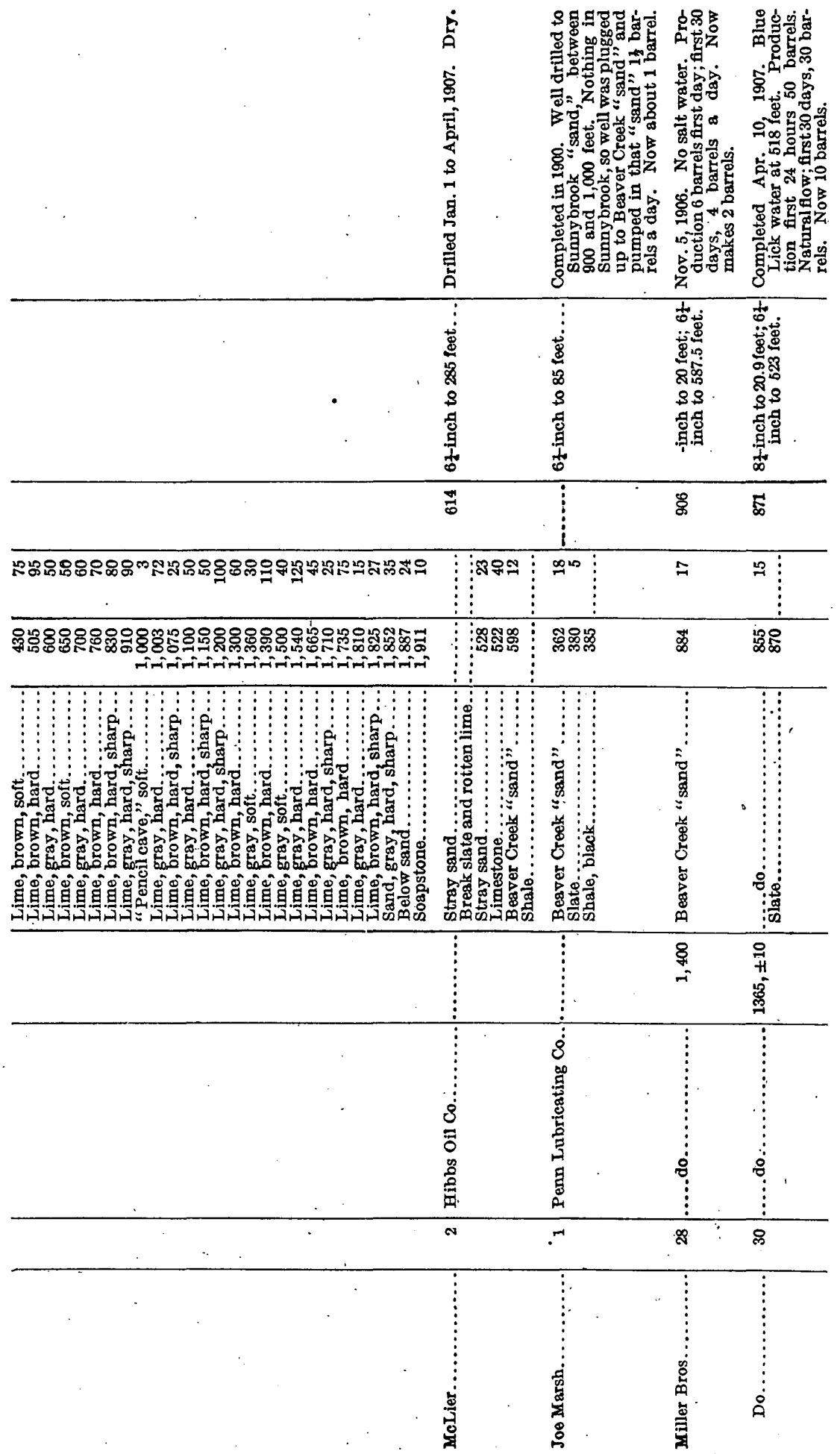




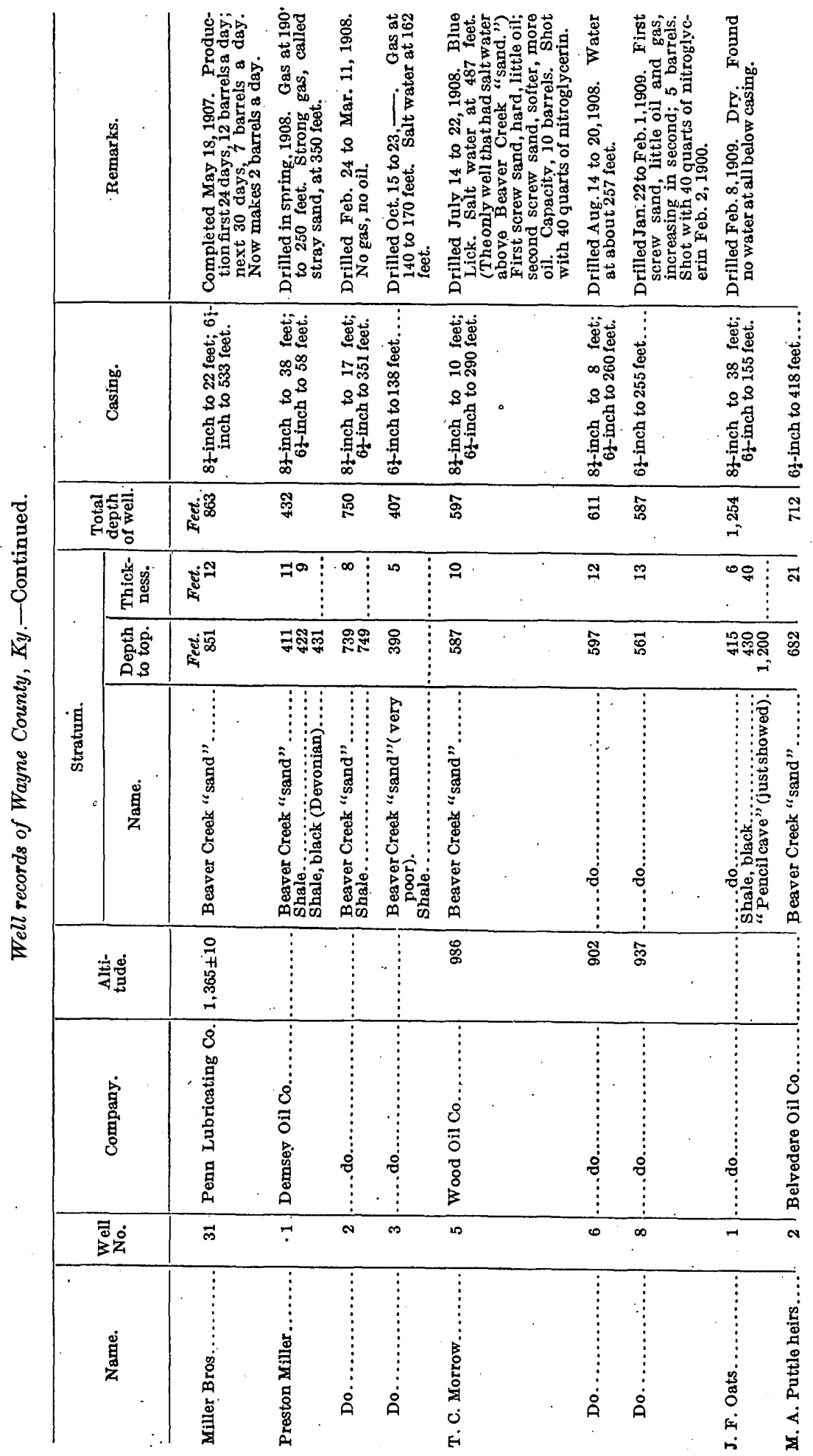




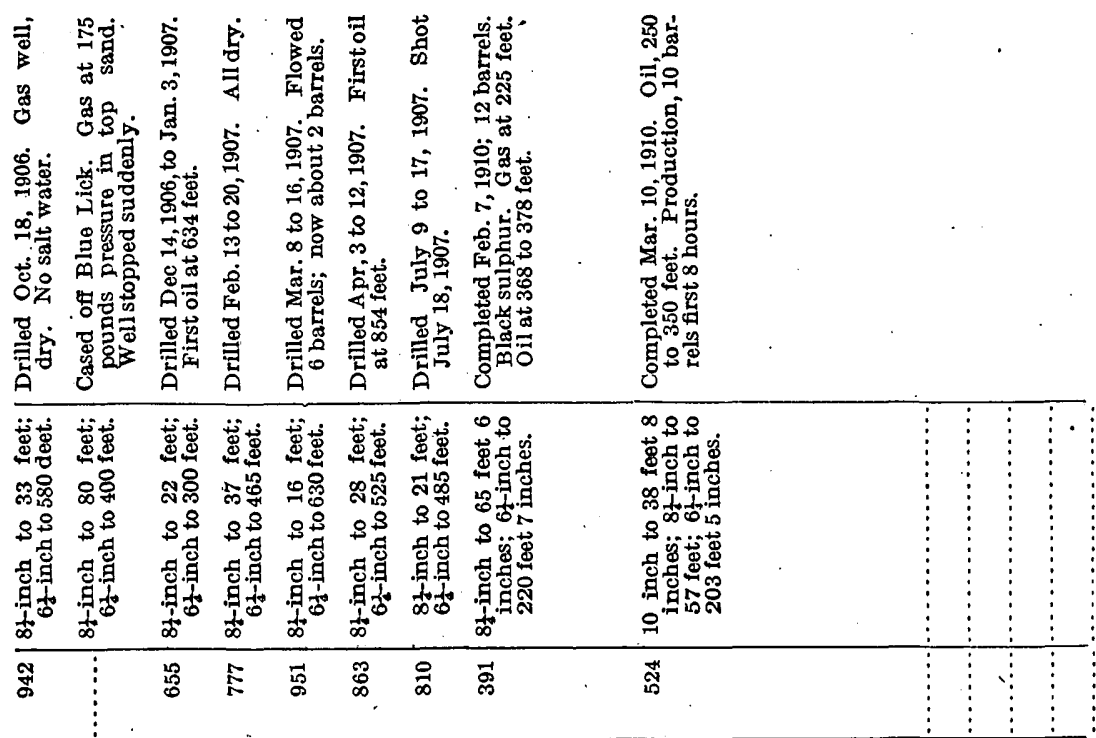

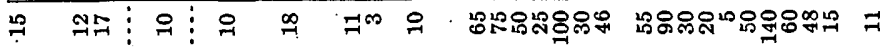
ส
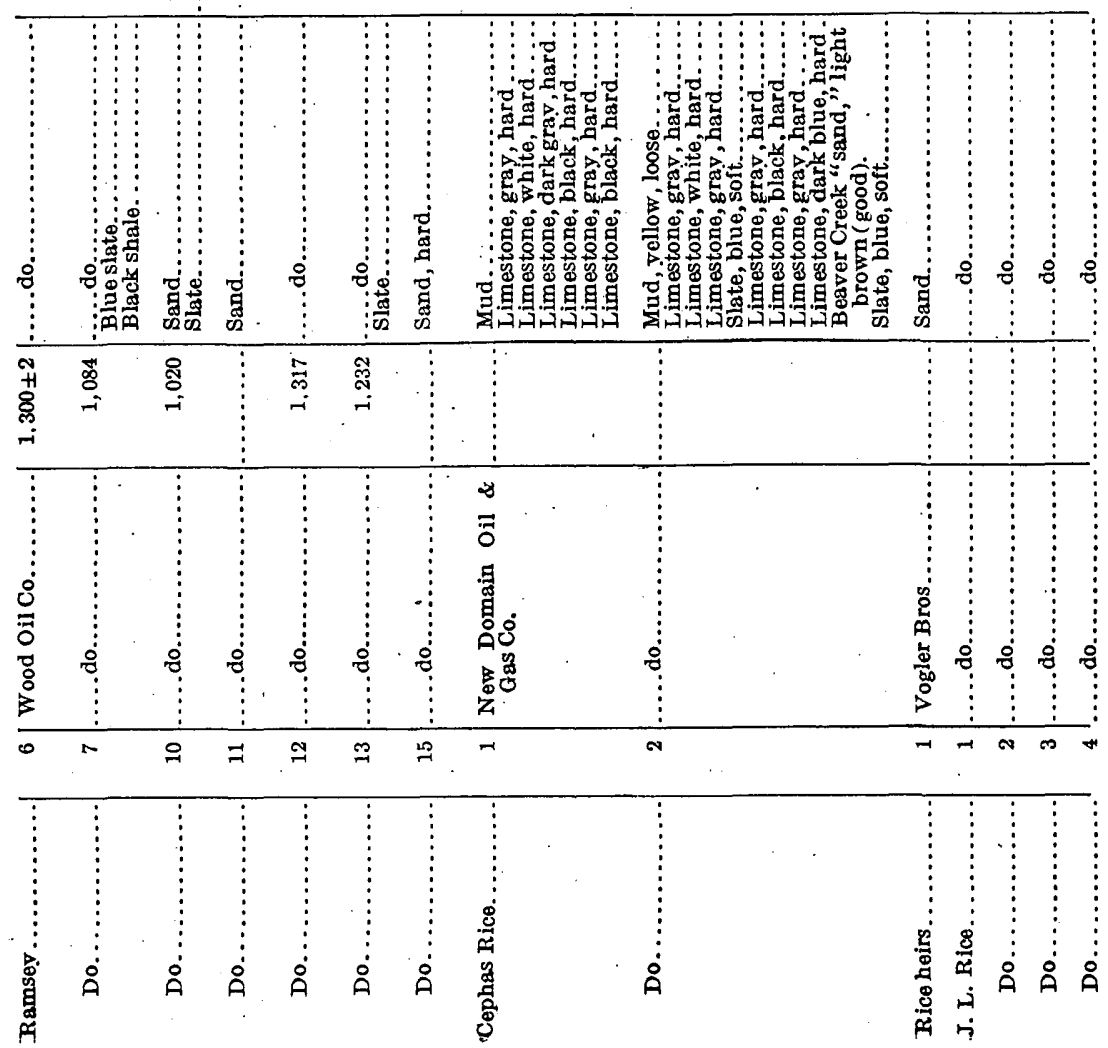
92 OIL AND GAS IN WAYNE AND MCCREARY COUNTIES, KY.

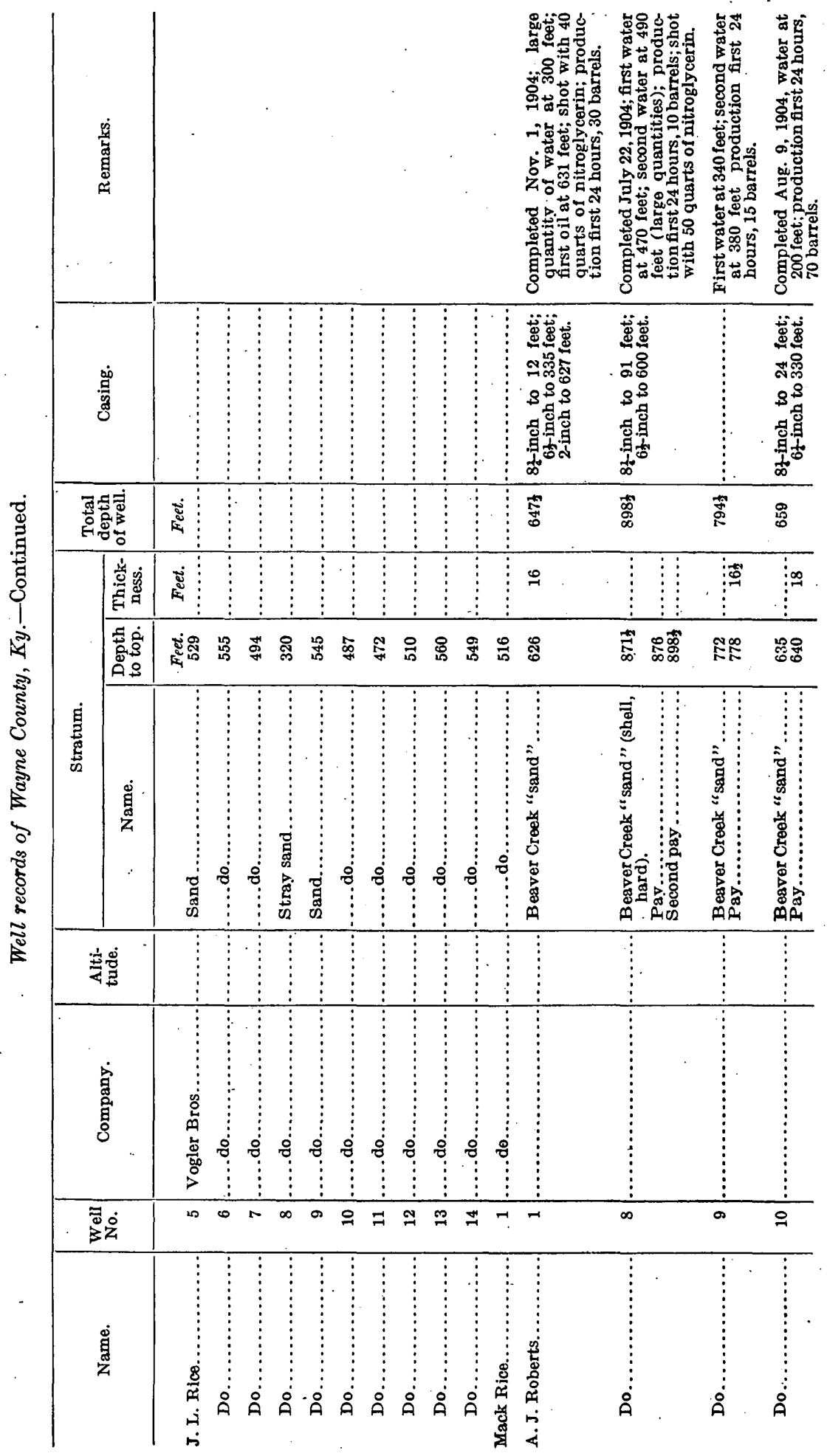


WELL RECORDS.

\begin{tabular}{|c|c|c|c|c|c|c|c|c|c|c|c|c|}
\hline 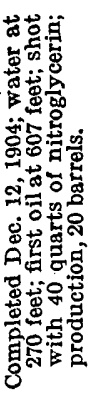 & 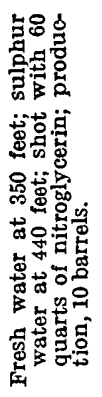 & & 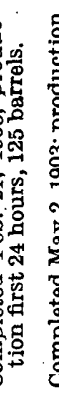 & 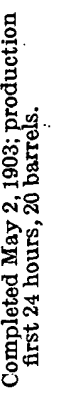 & 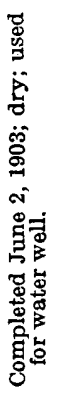 & 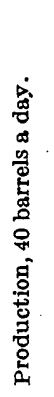 & 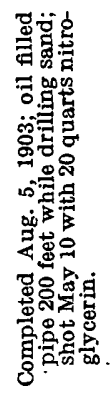 & 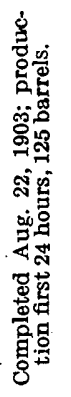 & 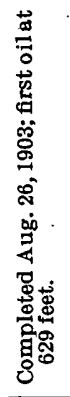 & $\dot{\Delta}$ & 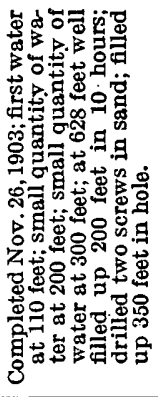 & 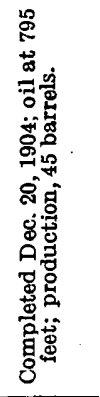 \\
\hline 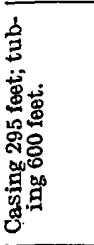 & 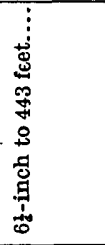 & & 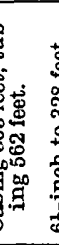 & 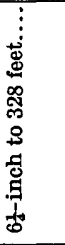 & & 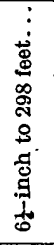 & 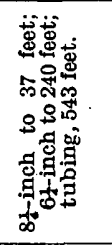 & 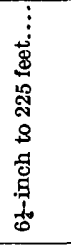 & & & 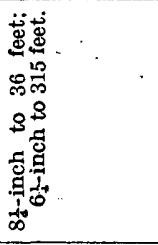 & 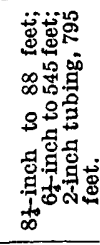 \\
\hline & 贺 & 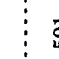 & ฮั & : & สิ๋ & $\stackrel{\circ}{\circ}$ & $\stackrel{\infty}{\stackrel{\infty}{40}}$ & $\bar{G}$ & & & 용 & $\stackrel{\infty}{\infty}$ \\
\hline 0 & $\stackrel{9}{2}$ & & H⿻ & $\underset{7}{200}$ & $\stackrel{\infty}{\sim}$ & & : & & & & $\nexists$ & $\mathbb{\sim}$ \\
\hline & $\vec{\Re}$ & & 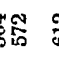 & ซี్้త్ & : & & 脶员 & స్రైశ్రి & & & 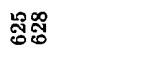 & 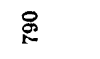 \\
\hline
\end{tabular}
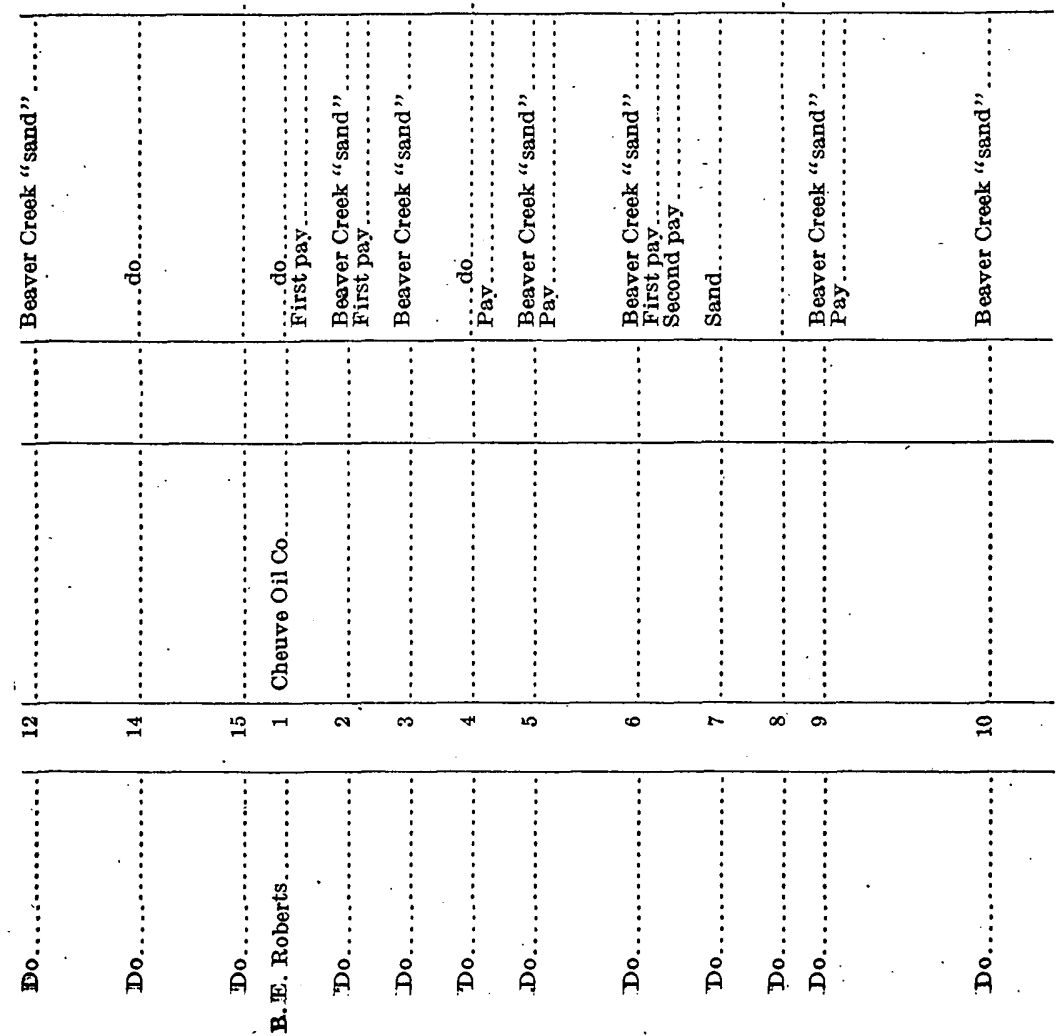
OIL AND GAS IN WAYNE AND MCCREARY COUNTIES, KY.

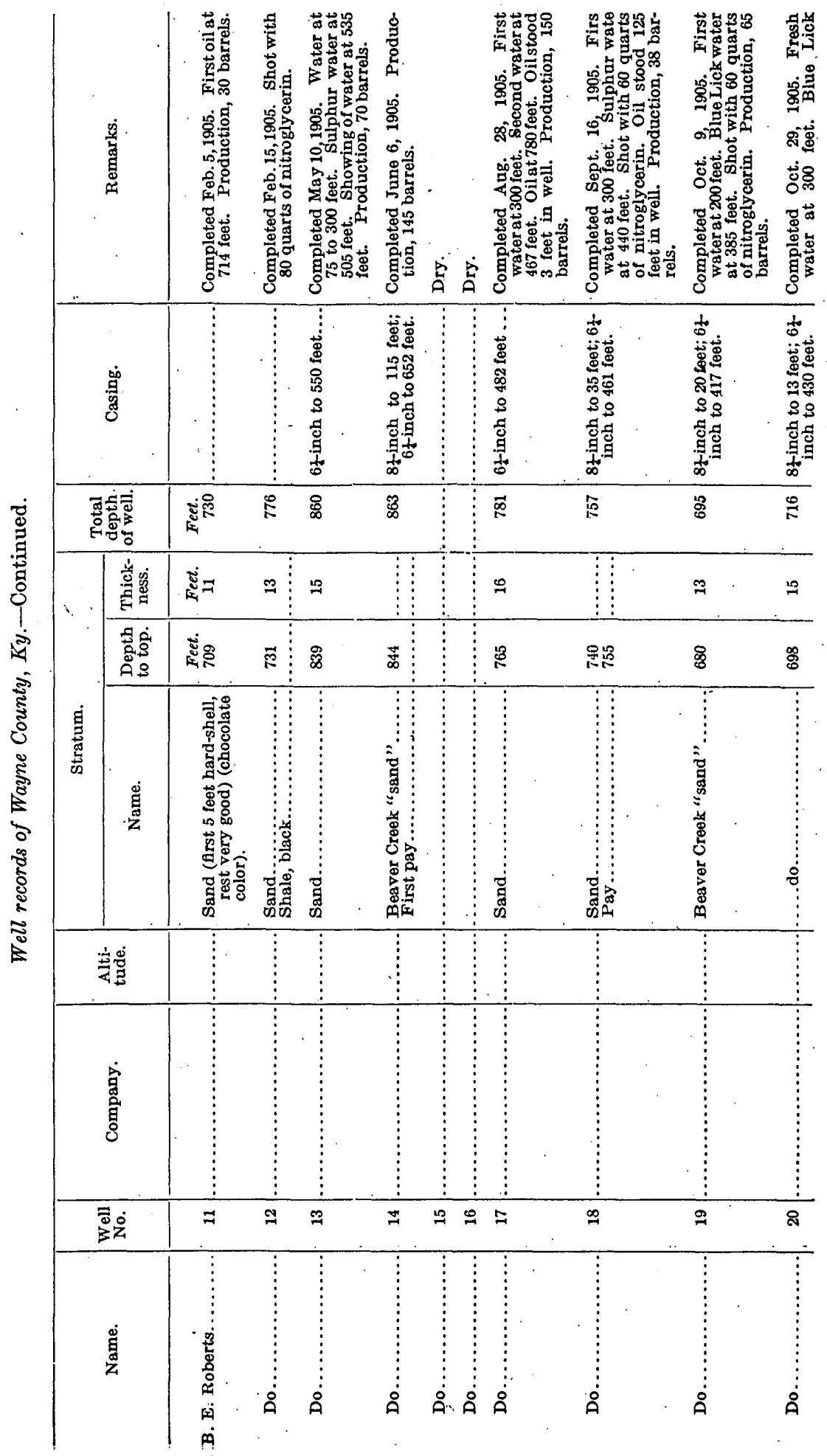




\begin{tabular}{|c|c|c|c|c|c|c|c|c|c|}
\hline 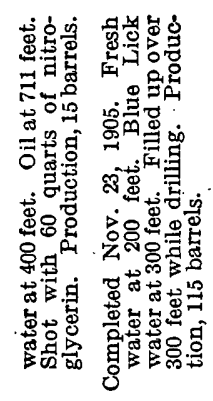 & 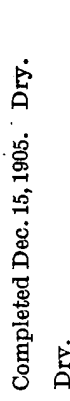 & 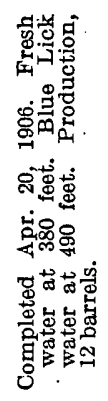 & 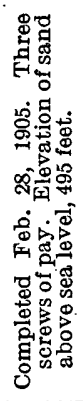 & 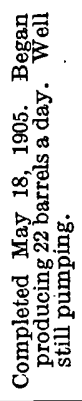 & 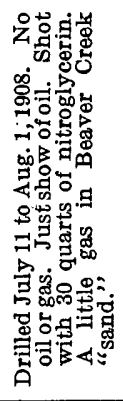 & 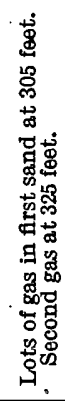 & 宫 & 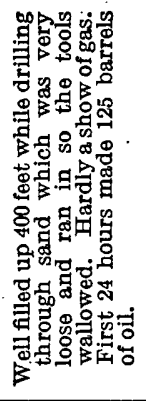 & 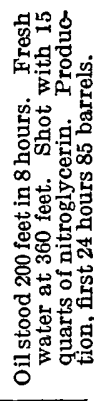 \\
\hline 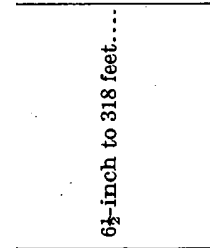 & 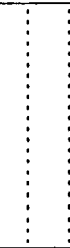 & 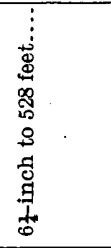 & $\begin{array}{c}\vdots \\
\vdots \\
\vdots \\
\vdots \\
\vdots\end{array}$ & & 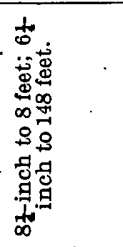 & 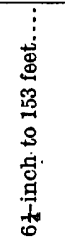 & & 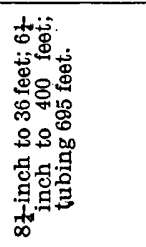 & 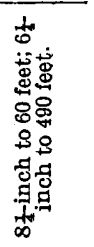 \\
\hline & & $\stackrel{\infty}{\stackrel{\infty}{N}}$ & $\stackrel{\circ}{\sigma}$ & 恋 & 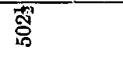 & & & $\hat{E}$ & \\
\hline ลి & & 2 & 3 & $\begin{array}{l}\dot{0} \\
\dot{\tilde{n}}\end{array}$ & $\operatorname{Ran}$ & & & $\hat{A}$ & \\
\hline$\vec{్}$ & & $\stackrel{R}{R}$ & $\Xi_{\infty}$ & $\begin{array}{l}0 \\
\text { षें }\end{array}$ & 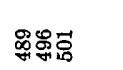 & & 范 & §ి & సేळ。 \\
\hline
\end{tabular}
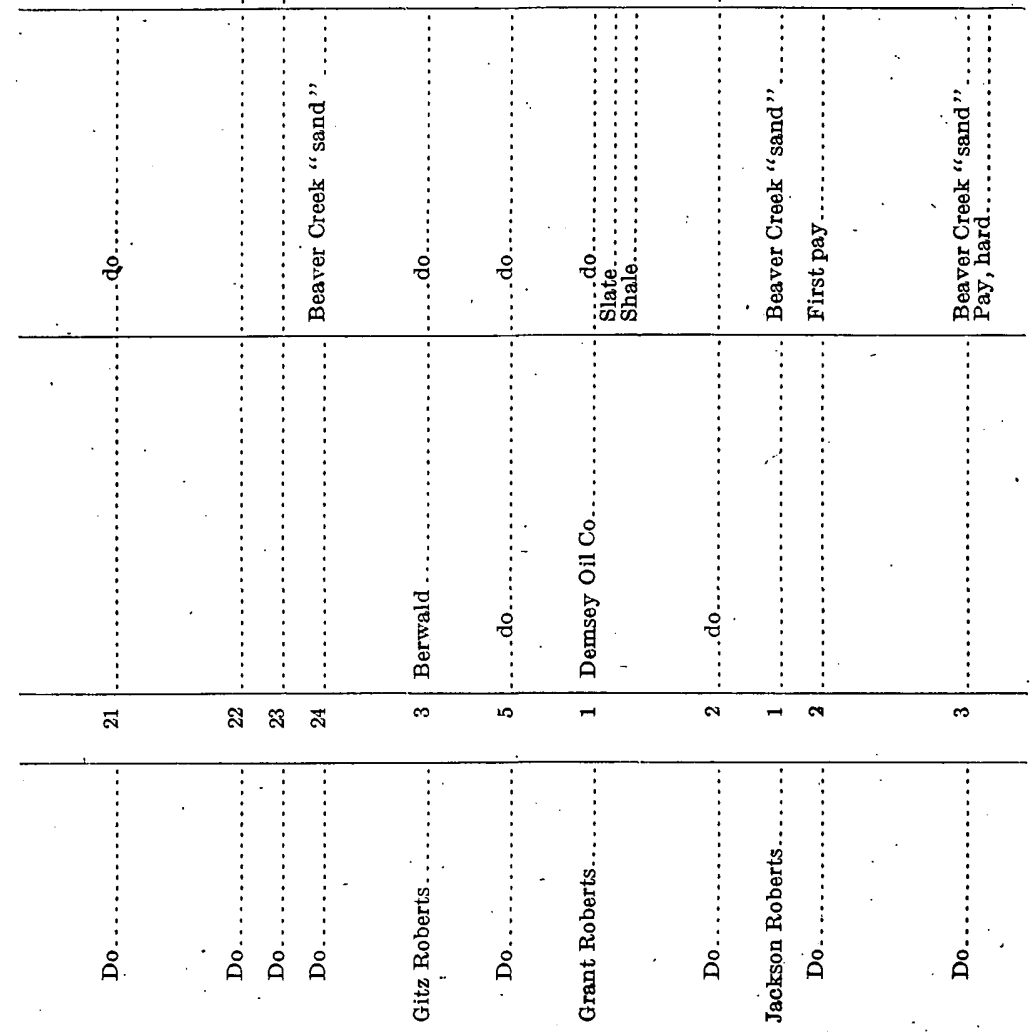
OIL AND GAS IN WAYNE AND MCCREARY COUNTIES, KY.

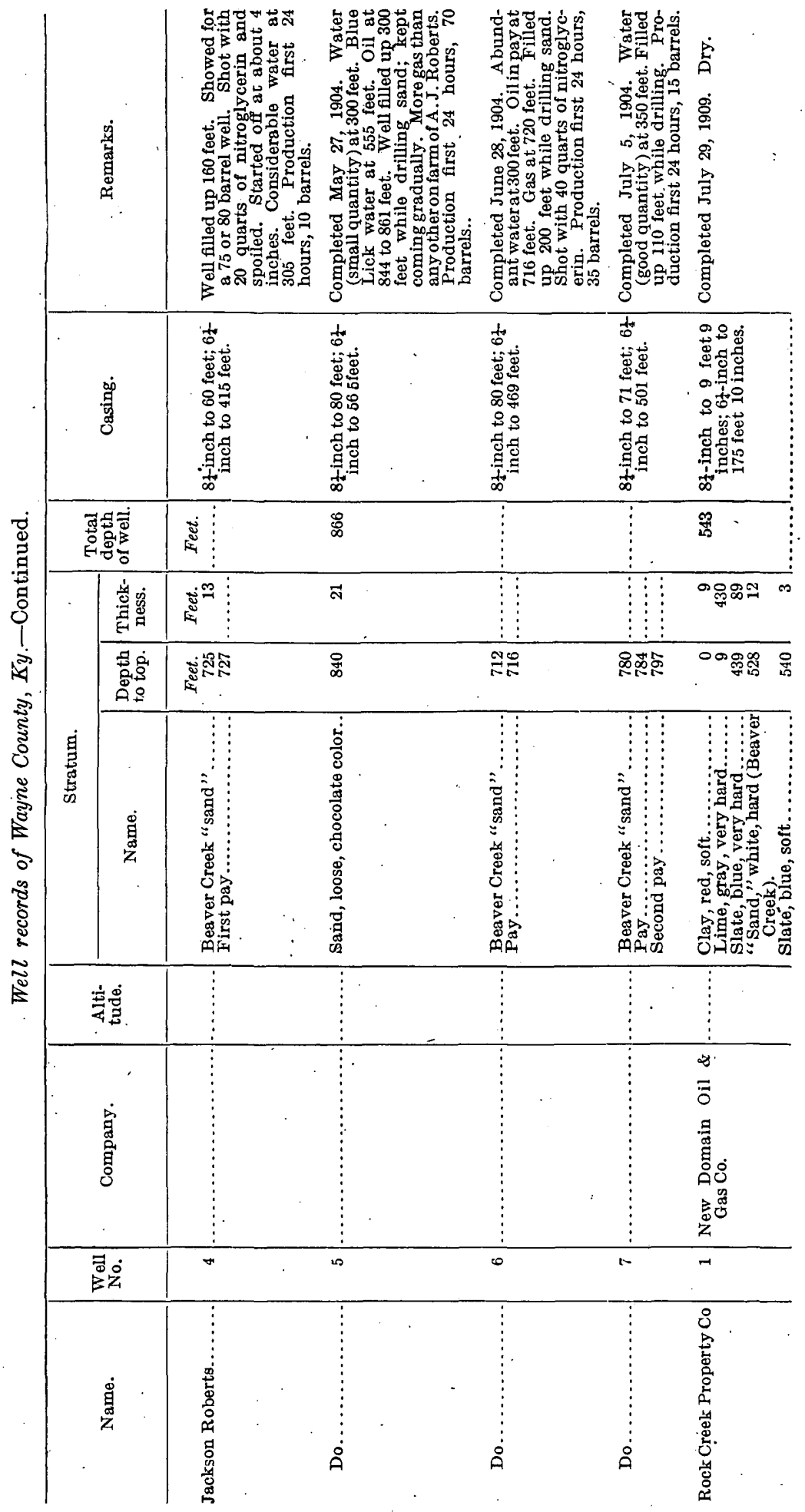




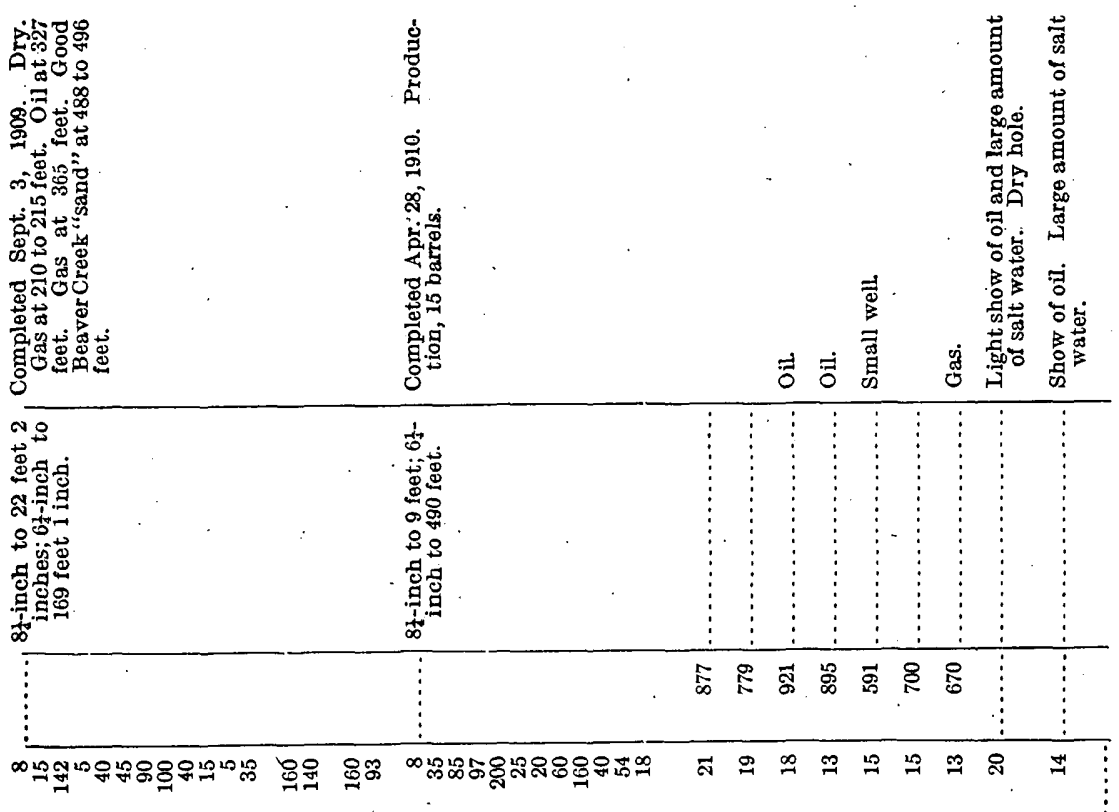

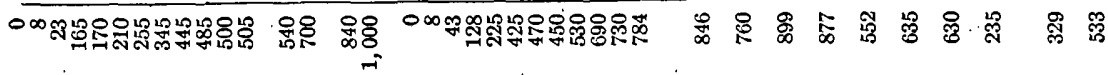
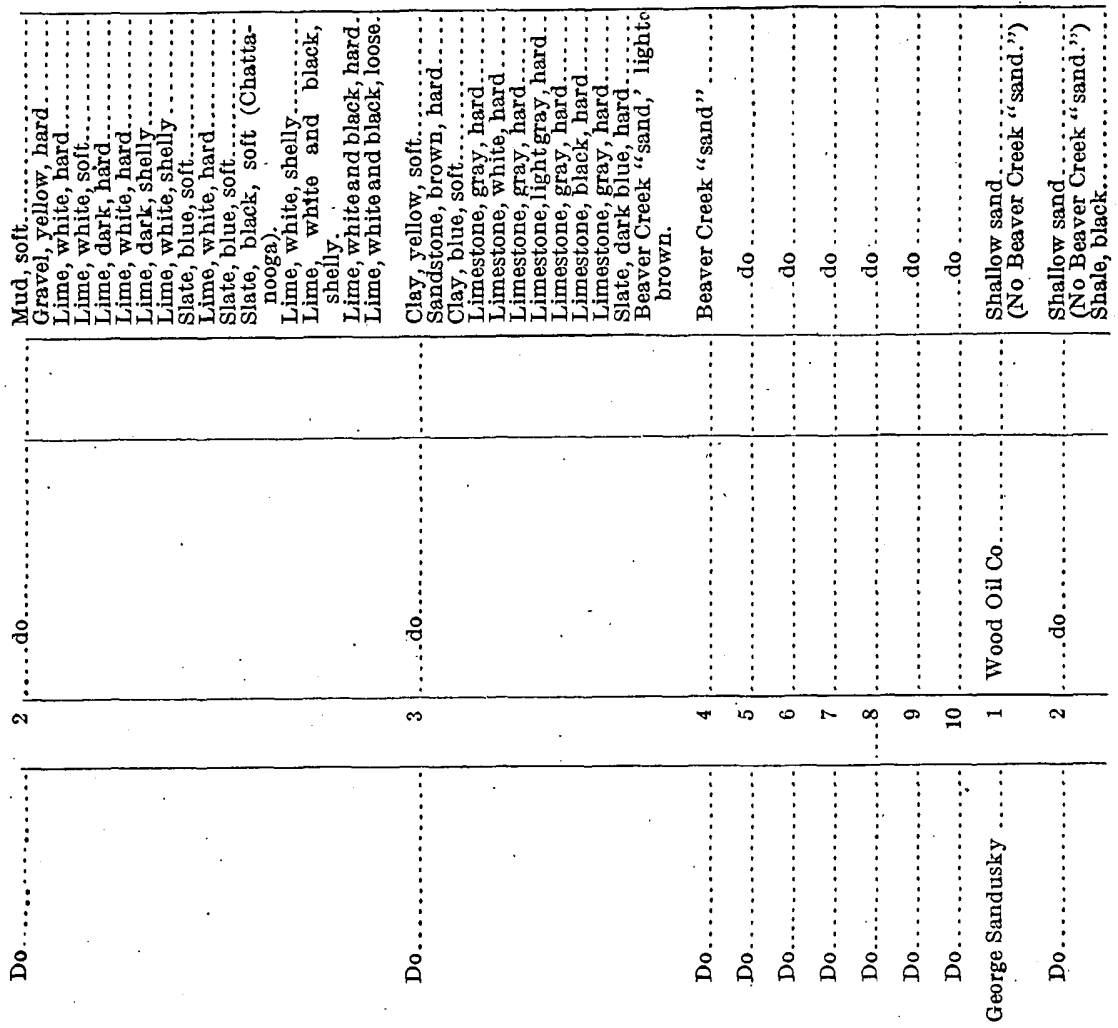


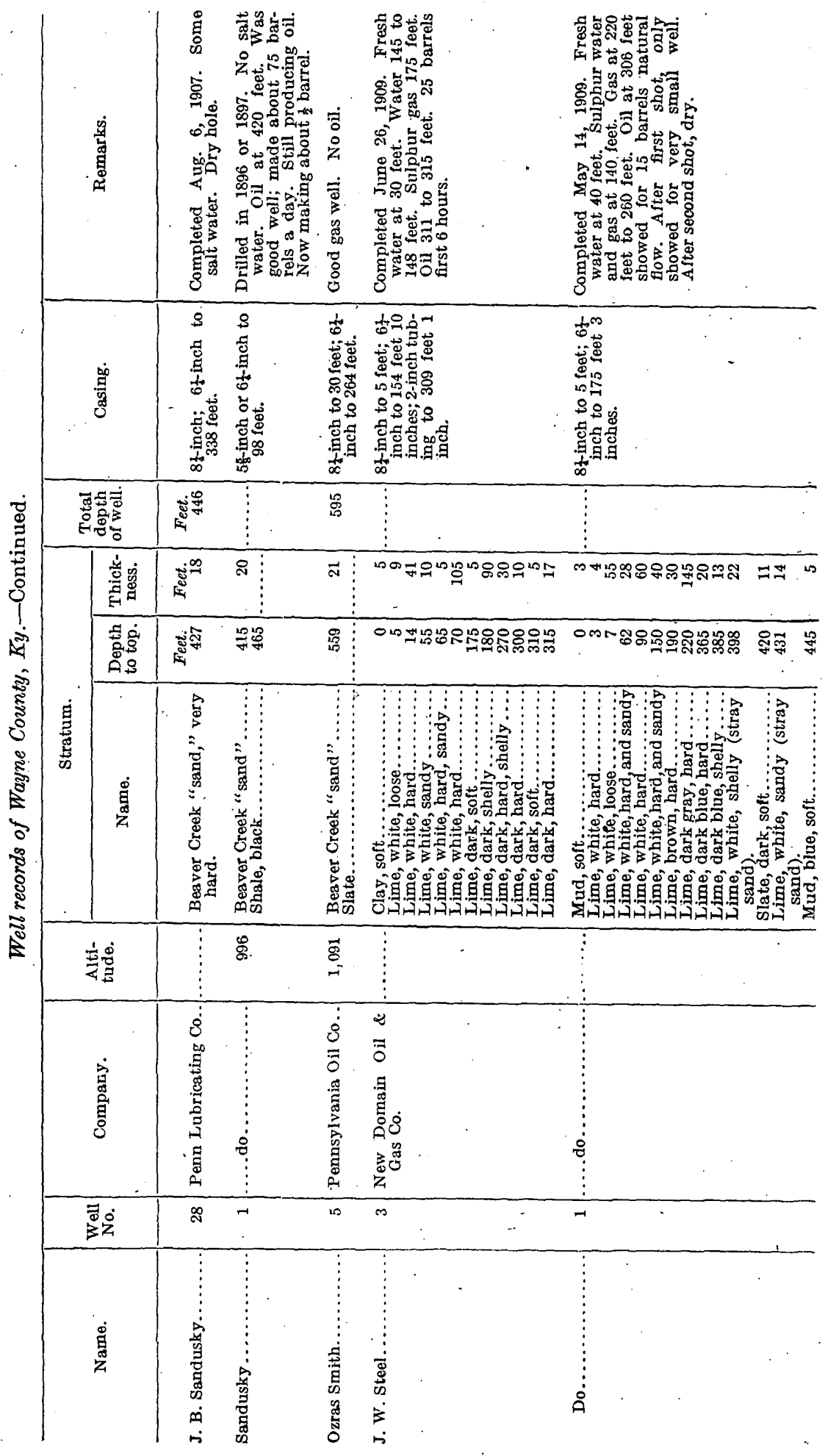




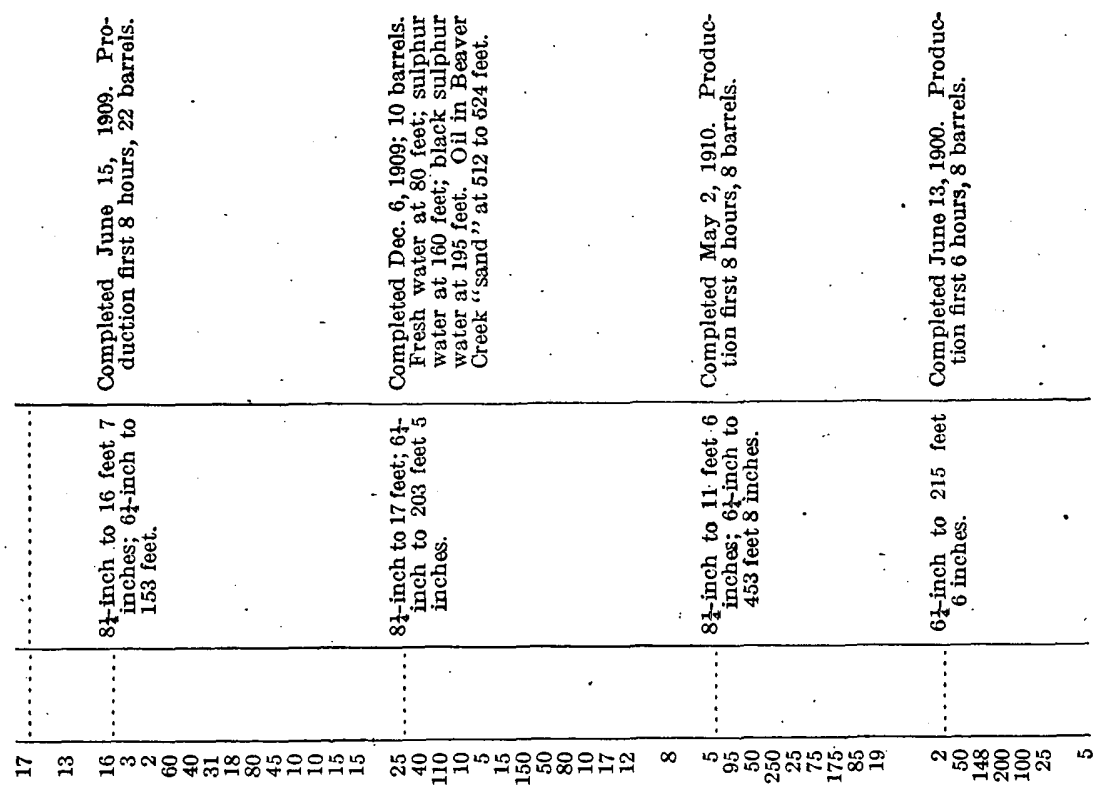

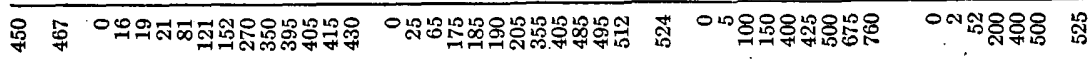
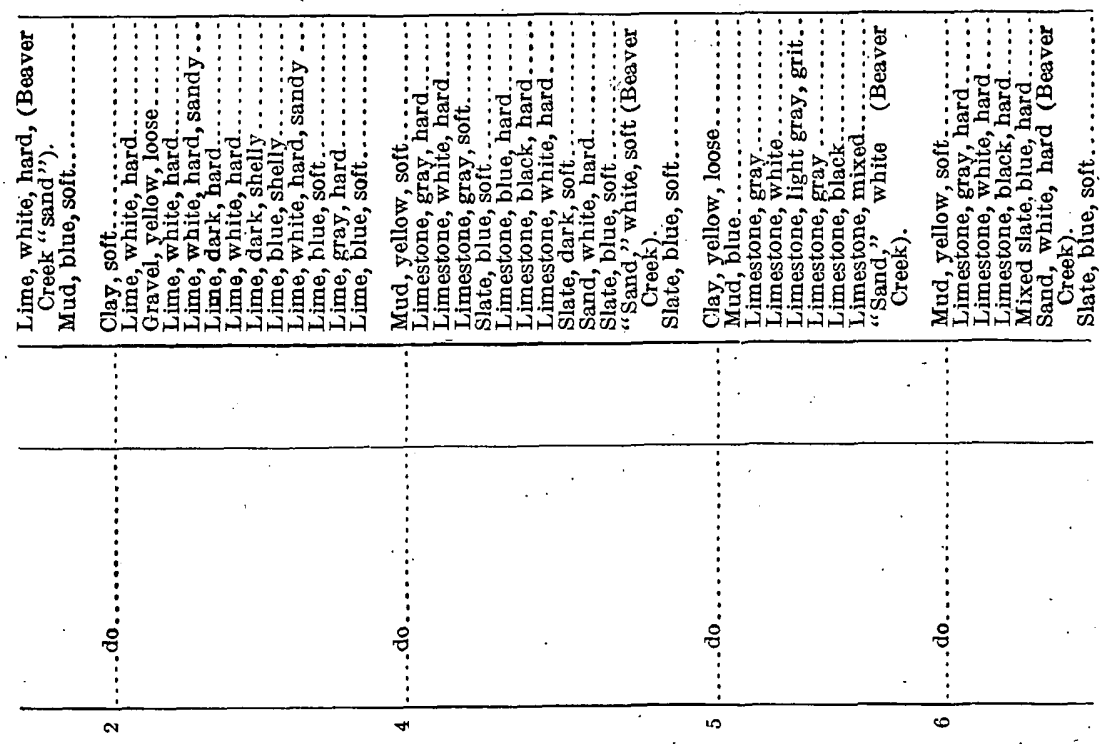
OIL AND GAS IN WAYNE AND MCCREARY COUNTIES, KY.

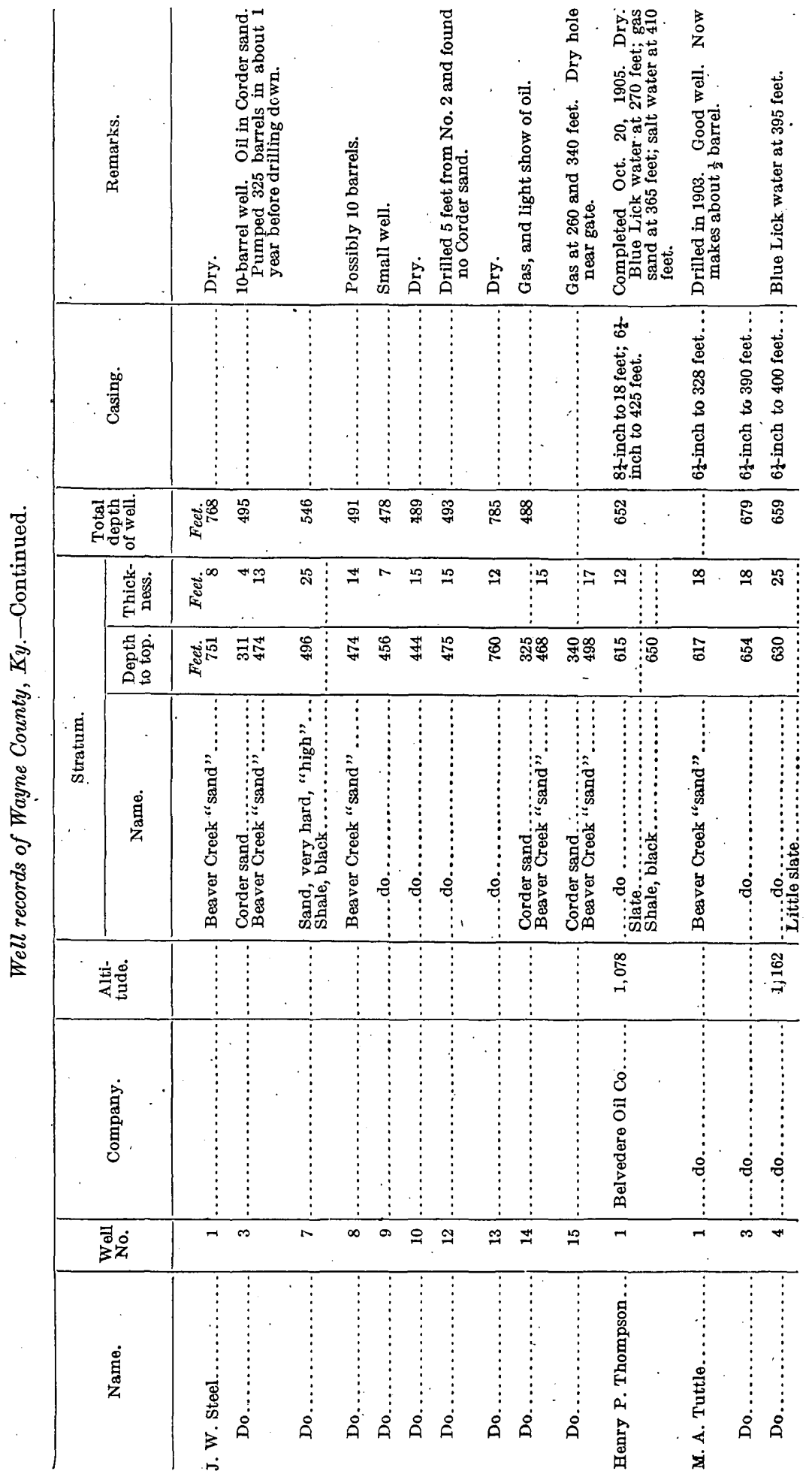




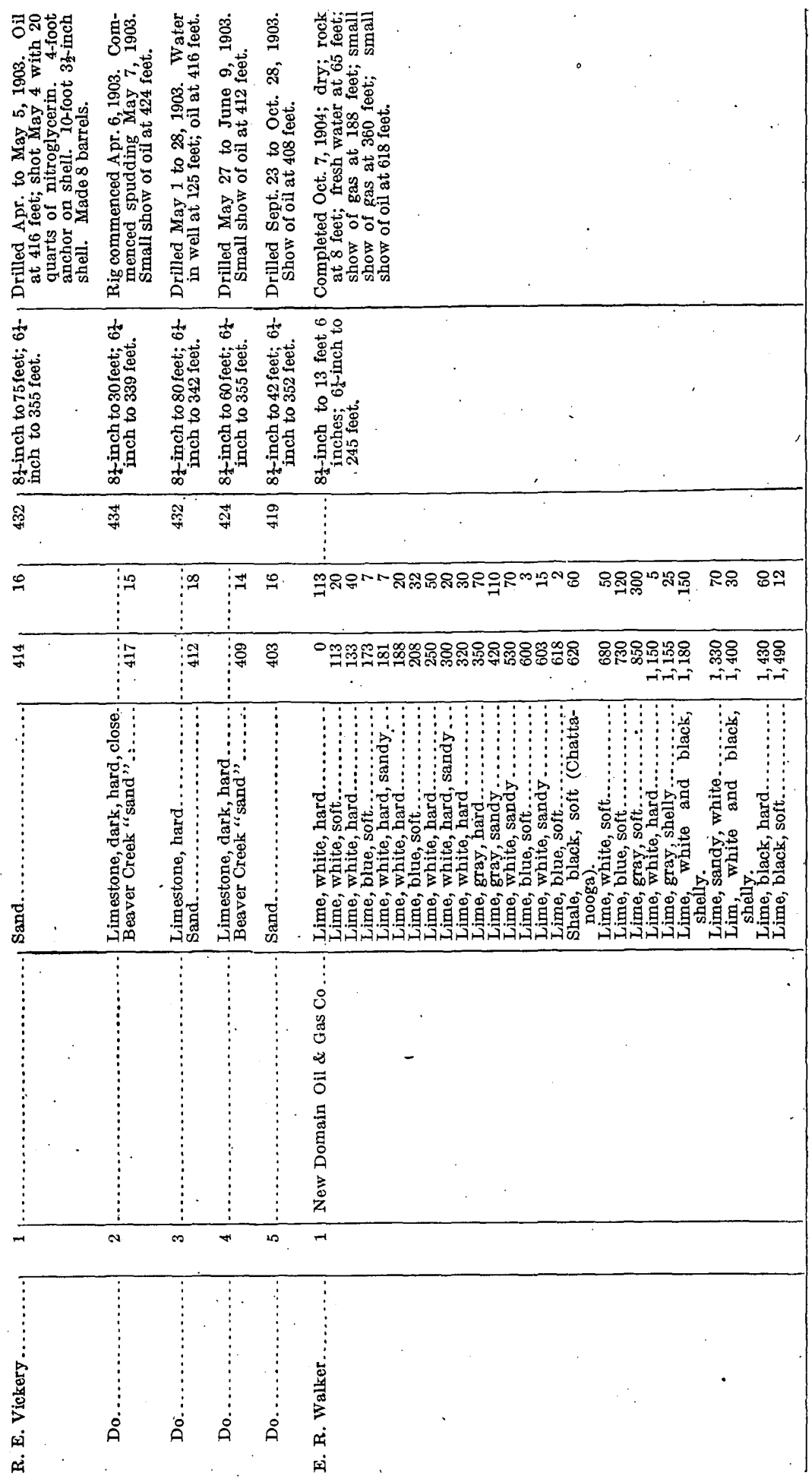





\section{INDEX.}

A.

Acknowledgments to those aiding............

Analyses of oil, table of...

B.

Barnes (J. W.) well, record of ......... 13, 17, 51 record of, figure showing............. 16

Barrier oil field, description of ............. 47

Beaver Creek, location and character of..... $9 ; 10$ sections on....................... 23,27

Beaver Creek "sand," oil from............. 28 specimens from, views of .............28, 29 structure contours on................. 36 See also particular fields, wells, etc.

Bethesda, wells near..................... -51

Big Sinking Creek, location of.............. 9 well on, record of ................... 14-15 figure showing................. 16

Black shale. See Chattanooga shale.

Blue Lick water, source of ............ 41-42, 47

Boyle limestone, occurrence and character of. . 24

Bratcher Hollow oil pool, description of...... 46

Brown (Cyrus) well, record of. 13-14, 44-45, 55, 66-67 record of, figure showing............. 16

C.

Carboniferous system, character of.......... 24 section of, figure showing.............. 25 See also Mississippian; Pennsylvanian.

Chattanooga shale, correlation of .......... 23 occurrence and character of............ 17,23 section of .......................... 23

Chazyan series, classification of ........... 19,21

Cincinnati anticline, rocks on............. 22 rocks on, figure showing.............. 22

Cincinnatian series, classification of ........ 18-21

Contours, structure. See Structure contours.

Cooper anticline, structure of .............. 38

Cooper-Oil Valley field, history of .......... 47-48

location of ........................... 47 map of ............................ 49

oil from, analysis of................... 63 oil sand in ......................... 48,50

production from................. 51

structure of......................... 48,61

water in............................ 48-51

Corder pool, description of............... 53

Correll, wells near...................... $52-53$

D.

Day, D. T., analyses by

Denny, wells near

Devonian system, distribution and character of ......................11, 23-24 section of $. \ldots \ldots \ldots \ldots \ldots \ldots \ldots \ldots \ldots \ldots . .23$

Drainage, description of . . . .

Drilling, methods of..................... 62

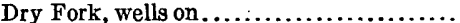

Dry Fork pool, description of.
E.

Page.

Economic conditions, abstract of ........... 62

Eden shale, occurrence and character of...... 18-20

Elk Spring Creek, location of .............. 9

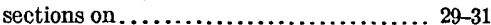

wells on...........................

F.

Fannys Creek, wells on .................. $\quad 53$

Field work, extent of ..................... 8-9

Foerste, A., classification by.............. 18 correlation by ....................... 25 section by ......................... 22

Frazier, wells near...................... 52

G.

Gas fields. See Oil and gas fields.

Geology, description of ................... 11-39

Gibson oil pool, description of.............. 46

Girty, G. H., correlation by.............. 32

Griffin field, Beaver Creek sand from, view of 28 extensions of ......................... 60

history of............................ 58-59

structure of......................... 59,61

water in $\ldots \ldots \ldots \ldots \ldots \ldots \ldots \ldots \ldots \ldots .6,60$

well in, record of..................... 15,60

record of, figure showing........... 10

H.

Highbridge formation, occurrence and character of ................. 18,20,21

Hoeing, J. B., classification by............ 18

I.

Index map, figure showing.

J.

Jessamine series, occurrence and character of. $\quad 18$ Johnson Fork pool, description of ........... 53-54 coil from, analysis of.................. 63

Jordan \& McGowan well, record of . ... 12-13,17, 88 record of, figure showing............... 16

$\mathrm{K}$.

Kentucky, cooperation with............... 8

Kindle, E. M., correlation by .............. 25

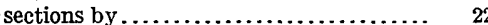

L.

Lee formation, distribution and character of. Lexington formation, occurrence and charac-

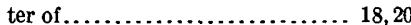

Little Cub Creek, section on................ 22

Little Sinking Creek, wells on.............. 44

Little South Fork, location of............... 9

Little South Fork district, map of .......... 56

Location of area.......................... 7

map showing...................... ? 
M.

McBeath (H.) well, record of............ 12,17,88 record of, figure showing............... 16

McCreary County, location of............... 7 location of, map showing............... 7

Map of I.ittle South For 1 district........... 56 of part of Monticello quadrangle........ 34 of Wayne County .................... 38,54

Map, index, showing location of area........ 7

Matson, G.C., classification by............. 19-20

Maysville formation, occurrence and character of ...................... 18-20

Meadow Creek, wells on................. 42

dill Springs, wells near................... 52

Mississippian series, deposition of........... 24 distribution and character of......... 11, 24-34 oil sands in......................... 35

See also Waverly formation.

section of, figure showing.............. 25

structure of........................... 35

subdivisions of ..................... 24-26

Mohawkian series, classification of ......... 19,21

Monticello, sections near................. 29-32 topography near................... 10 wells near......................... 43

Monticello district, structure of . ............ 36-39 wells near.......................... 43,46

Monticello quadrangle, map of part of...... 34

Monticello syncline, wells on.............. 43

Mount Pisgah field, Beaver Creek sand from, view of $\ldots \ldots \ldots \ldots \ldots \ldots \ldots . .28$

history of $\ldots \ldots \ldots \ldots \ldots \ldots \ldots \ldots \ldots . .56-57$

structure of......................... 57,61

water in ........................... 57

Murl, well at, record of .................. 13,51 well at, record of, figure showing........ $\quad 16$

\section{N.}

Newman limestone, distribution and character of................... 25, 29-32 sections of .......................... 25-31

Norwood, C. J., aid of...

O.

Oil and gas fields, conclusions on ..........61-62 description of ......................... $39-60$ examination of ....................... 39

Oil sands, structure and position of......... $28^{*}-29$ structure of, determination of ........... 8-9

Ordovician rocks, classification of ,......... 18-20 distribution and character of.......... 11,12-21 wells in, sections of................... 12-15 figures showing.................. 16

Otter Creek, location and character of....... 9,10 wells on .............................. 52

\section{P.}

Parmleysville, sections near.............. 31-33 Parmleysville district, description of......... 56-60 structure of....................... 38-39

Parmleysville field, history of............ 57-58 oil from, analysis of................... 63 structure of.......................... 58,61 water in ........................... 58

Parnell, section near..................... 26-27 wells near..

Page.

oil from, analysis of.................... 63

Pencil cave, occurrence and character of..... 17,21

Pennington shale, distribution and character of ......................... 32-34

seetion of ............................ 32

See also Spann limestone member.

Pennsylvanian series, distribution and character of................... 11, 24,34

section of, figure showing ............... 25

Plan of report........................ 7-9

Pottsville group, distribution and character of 34

Pueblo, wells near...................... 53

R.

Relief, description of . ................... 10

Richmond formation, occurrence and character of ................... 18, 20

Rockcastle conglomerate member, distribution and character of........... 34

Rock Creek, location of................... 9 wells on .......................... 54

Rock Creek Property Co. well, record of. 15,60,96-97 record of, figure showing.............. 16

Rocks exposed, description of. .......... 11, 21-34

Rocks not exposed, description of......... 11-21

Rocky Branch pool, description of......... 54 oil from, analysis of.................. 63

S.

St. Peter sandstone, occurrence and character of ......................... 17,20

Shearer Valley, wells in................ 51

Silurian system, distribution and character

of . ...................... 21-22 position of figure showing.............. 22

Sink holes, prevalence of . ............... 9-10

Sinking oil field, description of............ 44-46

map of............................ 45

oil from, analysis of.................. 63

Slickford oil field, description of ............ $55-56$

South Fork, location of................. 9

wells on............................. . 54

Spann anticline, structure of .............. 37

Spann limestone member, distribution and character of.................. 33-34

structure contours on ................ 9,36

determination of ................. 9

plate showing..................... 34

Steubenville, wells near . . . . . . . . . . . . . . $42-44$

wells near, records of ................. 12

record of, figures showing............ 16

Steubenville oil field, gas in.............. 42

history of.......................... 39

oil sand of .......................... 40

production of...................... 40

structure of ......................... 40-41

water in ............................. 41

wells of ............................ 42-44

Steubenville syncline, structure of ........... 37

Stillhouse Hollow pool, structure in........ 48

Stratigraphy, description of................ 11-34

Stray sand, oil and gas from............... 29 See also particular districts, wells, etc.

Structure, details of....................... 36-39 general features of .................. 34-35 mapping of ........................... $35-36$ 


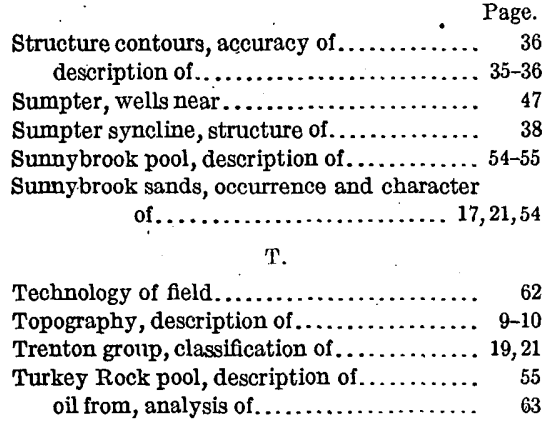

$\mathrm{U}$.

Ulrich, E. O., classification by

W:

Walker (E. R.) well, record of. 14-15 record of, figure showing.

Waverly formation, correlation of. distribution and character of.

Waverly formation, oil sands in......... sections of

Wayne County, location of .................. 7 location of, map showing.............. 7 maps of.......................... 38,54 northern and eastern parts of, wells in ... 52-53 southern part of, wells in ............. 53-56 western part of, wells in .............. 50-52

Wells, cost of .......................... 62 drilling of, methods of .................. 62 oil from, analyses of ................ 62-63 records of, alphabetic list of ............ 64-101 See also particular fields.

Winchester limestone, occurrence and character of..

Y.

Young pool, description of............... $\quad 56$

Z.

Zola, wells near....................... 52 